\title{
Tissue factor pathway inhibitor in patients with Diabetes Mellitus: an epiphenomenon?
}

Citation for published version (APA):

Leurs, P. B. (2001). Tissue factor pathway inhibitor in patients with Diabetes Mellitus: an epiphenomenon? [Doctoral Thesis, Maastricht University]. Datawyse / Universitaire Pers Maastricht. https://doi.org/10.26481/dis.20010126pl

Document status and date:

Published: 01/01/2001

DOI:

10.26481/dis.20010126pl

Document Version:

Publisher's PDF, also known as Version of record

\section{Please check the document version of this publication:}

- A submitted manuscript is the version of the article upon submission and before peer-review. There can be important differences between the submitted version and the official published version of record. People interested in the research are advised to contact the author for the final version of the publication, or visit the DOI to the publisher's website.

- The final author version and the galley proof are versions of the publication after peer review.

- The final published version features the final layout of the paper including the volume, issue and page numbers.

Link to publication

\footnotetext{
General rights rights.

- You may freely distribute the URL identifying the publication in the public portal. please follow below link for the End User Agreement:

www.umlib.nl/taverne-license

Take down policy

If you believe that this document breaches copyright please contact us at:

repository@maastrichtuniversity.nl

providing details and we will investigate your claim.
}

Copyright and moral rights for the publications made accessible in the public portal are retained by the authors and/or other copyright owners and it is a condition of accessing publications that users recognise and abide by the legal requirements associated with these

- Users may download and print one copy of any publication from the public portal for the purpose of private study or research.

- You may not further distribute the material or use it for any profit-making activity or commercial gain

If the publication is distributed under the terms of Article $25 \mathrm{fa}$ of the Dutch Copyright Act, indicated by the "Taverne" license above, 


\section{TISSUE FACTOR PATHWAY INHIBITOR IN PATIENTS WITH DIABETES MELLITUS: AN EPIPHENOMENON?}


OPB Leurs, Kattendijke 2001

ISBN $90-5278-296-2$

Universitaire Pers Maastricht

Publication of this thesis was financially supported by Baxter, Gambro, Janssen-Cilaq.
MSO. Novo Nordisk and Pfizer. 


\title{
TISSUE FACTOR PATHWAY INHIBITOR IN PATIENTS WITH DIABETES MELLITUS: AN EPIPHENOMENON ?
}

\author{
PROEFSCHRIFT
}

ter verkrijging van de graad van doctor aan de Universiteit Maastricht, op gezag van de Rector Magnificus,

Prof. dr. A.C. Nieuwenhuijzen Kruseman, volgens het besluit van het College van Decanen, in het openbaar te verdedigen op vrijdag 26 januari 2001 om 16.00 uur door

\section{Paul B. Leurs}

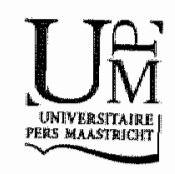




\section{Promotor}

Prof.dr. A.C. Nieuwenhuijzen Kruseman

\section{Co-promotores}

Dr. B.H.R. Wolffenbuttel

Dr. K. Hamulyák

\section{Beoordelingscommissie}

Prof.dr. P.W. de Leeuw (voorzitter)

Dr. M.J. Lindhout

Prof.dr.ir. R.P. Mensink

Prof.dr. P. Smits (Katholieke Universiteit Nijmegen)

Prof.dr. J.S. Yudkin (University College Londen) 
Aan mijn vader en mijn broer Rob 



\section{Contents}

Chapter 1 Introduction 9

Chapter 2 Tissue factor pathway inhibitor in physiologic and pathologic conditions 15

Chapter 3 Tissue factor pathway inhibitor activity in patients with type 1 diabetes mellitus 35

Chapter 4 Tissue factor pathway inhibitor release after heparin stimulation is increased in type 1 diabetic patients with microalbuminuria 49

Chapter 5 Increased tissue factor pathway inhibitor and coagulation in patients with type 1 diabetes mellitus 63

Chapter 6 Tissue factor pathway inhibitor and other endothelium-dependent factors in the elderly with normal or impaired glucose tolerance and diabetes mellitus type $2 \quad 77$

Chapter 7 Tissue factor pathway inhibitor release from cultured endothelial cells under normo- and hyperglycemic conditions $\quad 91$

Chapter 8 General discussion and conclusions 107

Chapter 9 Samenvatting 115

Dankwoord 121

Curriculum Vitae 125 



\section{Chapter 1}

Introduction 


\section{Introduction}

It is well known that diabetes mellitus can lead to premature atherosclerosis and subsequent cardiovascular events. This is especially true for type 2 diabetes, where the co-existence of hyperglycemia, dyslipidemia and hypertension greatly increases cardiovascular risks. In type 1 diabetes the occurrence of microvascular complications like retinopathy and (incipient) nephropathy prevails. (Micro)albuminuria thereby appears not only to be a marker of the development of nephropathy, but a strong predictor for cardiovascular disease as well ${ }^{1-4}$.

Also from a quantitative point of view diabetes is a disease of great importance. Because of increasing age, altered life styles and the application of more stringent criteria for diagnosis, the number of patients is sharply rising worldwides. This may explain the growing interest in preventive measures and interventions that could prevent the development of both type 1 (in ongoing studies like ENDIT using nicotinamide, or DPT-1 and EPP-SCIT using insulin ${ }^{6,7}$ ) and type 2 diabetes (by life style intervention and insulin-sensitizing drugs in DPP'). However, the results of these prevention trials will only be available in the next couple of years. Recently, the CAPPP and the HOPE study surprisingly suggested a decrease in the occurrence of (self-reported) diabetes, when patients with hypertension and/or cardiovascular disease were treated with an ACE inhibitor ${ }^{9,10}$. These interesting findings need further exploration and ascertainment.

Until the prevention of diabetes is a reality, we have to focus on the best possible treatment of the disease as well as on the prevention and treatment of its complications". In the last decade it has been clearly demonstrated that improvement of metabolic control will result in less secondary (microvascular) complications in type 1 (Diabetes Control and Complication Trial (DCCT) ${ }^{12.13}$ ) as well as in type 2 diabetes (United Kingdom Prospective Diabetes Study $\left(\right.$ UKPDS $\left.^{14}\right)$. In addition, recent epidemiologic analysis of the UKPDS shows that macrovascular complications are also less prevalent with lower levels of glycated hemoglobin"s. Endothelial damage precedes the development of atherosclerosis ${ }^{16}$. Increased levels of von Willebrand factor ( $\mathrm{WWF}$ ), thrombomodulin, tissue plasminogen activator (t-PA) and plasminogen activator inhibitor-1 (PAI-1) have been found in diabetic patients, especially in those with microvascular complications ${ }^{17-19}$. These alterations in endothelium-dependent hemostatic parameters may thereby reflect vascular endothelial damage. Most of these changes in levels are found when complications in the diabetic patient already exist. Until now, only VWF appears to precede the development of micro- and macroangiopathy in diabetes, and therefore may have a predictive value $\mathrm{e}^{20.21}$. We hypothesized that due to its specific characteristics and important role in endothelium-derived initiation of coagulation, tissue factor pathway inhibitor (TFPI) may also be a marker of endothelial dysfunction and may even play a role in the 
development of cardiovascular disease. This protein was identified in the late nineteen-eighties as a new Kunitz-type coagulation inhibitor". TFPI contains 276 amino acid residues and, as a natural anticoagulant, it plays a key regulatory role in tissue factor-initiated blood coagulation.

Under normal physiologic conditions, TFPI is mainly synthesized by and bound to the vascular endothelial cells ${ }^{23.24}$. It can be released from the endothelial cells by heparin ${ }^{25}$. TFPI can also be found in platelets and in plasma, mostly associated with lipoproteins ${ }^{26.27}$. Only a small portion is found in a free uncomplexed form ${ }^{28}$.

The studies represented in this thesis started late 1993. At that time, nothing was known about TFPI in diabetic subjects. These studies were specifically designed to evaluate not only the possible effect of diabetes on TFPI, but the possible role of TFPI in the development of vascular diabetic complications as well.

\section{Aims of the thesis}

In Chapter 2, we reviewed our present knowledge of TFPI in physiologic and pathophysiologic (non-diabetic) conditions. The studies described in the following chapters were undertaken to investigate the role of TFPI in diabetes. Firstly, we studied the effect of metabolic regulation on TFPI activity in type 1 diabetic patients without vascular complications, before and after intravenous administration of heparin (Chapter 3). Because TFPI activity may reflect endothelial damage, a second study was performed, in which we compared type 1 diabetic patients with and without microvascular complications (Chapter 4). As it has become clear that diabetes is characterized by the presence of a procoagulant state, TFPI activity could be influenced by this ${ }^{29.30}$. We therefore studied TFPI activity in type 1 diabetic patients and healthy volunteers in relation to coagulation using measurements of prothrombin $F_{1+2}$ fragments and endogenous thrombin potential (Chapter 5). While type I diabetes is mainly complicated by microangiopathy, type 2 diabetes is mostly complicated by macroangiopathy. The condition of impaired glucose tolerance is considered to be a transitional phase to type 2 diabetes. We studied in a population-based study TFPI activity and other endothelium-dependent factors in eldery subjects with a normal or impaired glucose tolerance and type 2 diabetes mellitus (Chapter 6). To study the effects of typical diabetic conditions, e.g. hyperglycemia and hyperinsulinemia, on TFPI activity and release in more detail, cultured endothelial cells, derived from an immortalized endothelial cell line (EA.hy 926), were used (Chapter 7). Finally, the results are summarized and discussed in the general discussion. 


\section{References}

1. Borch-fohnsen $K$, Andersen PK, Deckert $T$. The effect of proteinuria on relative mortality in type 1 (insulindependent) diabetes mellitus. Diabetologia 1985;28: $590-6$.

2. Mathiesen $\mathbb{E}$, Ronn B, Storm B, Foght H, Deckert T. The natural course of microalbuminuria in insulin-dependent diabetes: a 10-year prospective study. Diabet Med 1995:12:482-7.

3. Mogensen CE. Microalbuminuria predicts clinical proteinuria and early mortality in maturity onset diabetes. N Engl J Med 1984;310:356-60.

4. Mattock MB, Morrish NJ, Viberti G, Keen H, Fritgerald AP, Jackson G. Prospective study of microalbuminuria as a predictor of mortality in NIDDM. Diabetes 1992:41:736-41.

5. Expert Committee on the Diagnosis and Classification of Diabetes Mellitus. report of the Expert Committee on the Diagnosis and Classification of Diabetes mellitus. Diabetes Care, 2000;23(S1):S4-\$19.

6. Gale EAM, Bingley PJ. Can we prevent IDDM ? Diaberes Care 1994;17:339-44.

7. Carel $J C$, Bougnères $P F$. Treatment of prediabetic patients with insulin: experience and future. Horm Res 1996:45(S1):44-7.

8. The Diabetes Prevention Program Research Group. The Diabetes Prevention Program. Design and methods for a clinical trial in the prevention of type 2 diabetes. Diabetes Care 1999;22:623-34.

9. Hansson $L$, Lindholm LH, Niskanen L, Lanke J, Hedner T, Niklason A, Luomanmăki K, Dahlö $\mathrm{B}$, de Faire U, Mörlin C, Karlberg BE, Wester PO, Björck JE. Effect of angiotensinm converting-enzyme inhibition compared with conventional therapy on cardiovascular morbidity and mortality in hypertension: the Captopril Prevention Project (CAPPP) randomised trial. Lancet 1999;353:611-6.

10. Yusuf S, Sleight P, Pogue J, Bosch J, Davies $R$, Dagenais $G$. Effects of an angiotensin-converting-enzyme inhibitor, ramiprit, on cardiovascular events in highrisk patients. N Engl J Med 2000:342: 145-53.

11. Wolfenbuttel $B$, van Haften $T W$. The prevention of complications in non-insulin dependent diabetes mellitus. Drugs 1995;50:263-288.

12. Diabetes Control and Complications Trial Research Group. The effect of intensive treament of diabetes on the development and progression of longterm complications in insulin-dependent diabetes mellitus. N Engl I Med 1993;329:
977.86 .

13. Wolfenbuttel BHR. The DCCT: matabolic control matters. Neth J Med 1992;42: $241-5$.

14. UK Prospective Diabetes Study (UKPDS) Group. Intensive blood-glucose control with sulphonylureas or insulin compared with comentional treatment and risk of

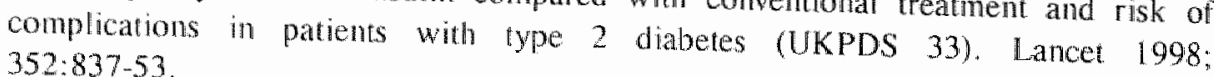


15. Adler Al. Neil AW, Manley SE, Holman RR, Turner RC. Hyperglycemia and hyperinsulinemia at diagnosis of diabetes and their association with subsequent cardiovascular disease in the United Kingdom Prospective Diabetes Study (UKPDS 47). Am Heart J 1999:S353-59.

16. Ross R. Atherosclerosis - an infammatory disease. N Engl J Med 1999:340:115-26.

17. Jensen T, Bjerre-Knudsen J, Feldt-Rasmussen B, Deckert T. Features of endothelial dysfunction in early nephroparhy. Lancet 1989;i:461-63.

18. Iwashima $\mathrm{Y}$, Sato $\mathrm{T}$, Watanabe $\mathrm{K}$, Ooshma $\mathrm{E}$, Hiraishi S, Ishii H. Kazama M, Makino I. Elevation of plasma thrombomodulin level in diabetic patients with early diabetic nephropathy. Diabetes 1990;39:983-8.

19. Collier A, Rumley A. Rumley AG, Paterson JR, Leach IP, Lowe GDO, Small M. Free radical activity and hemostatic factors in NIDDM patients with and without microalbuminuria. Diabetes 1992:41:909-13.

20. Stehouwer CD, Nauta JI, Zeldenrust GC, Hackeng, WH, Donker AJ, den Ottolander GJ. Urinary albumin excretion, cardiovascular disease, and endothelial dysfunction in non-insulin-dependent diabetes mellitus. Lancet 1992;340:319-23.

21. Stehouwer CDA. Stroes ESG, Hackeng WHL, Mulder PGH, den Otterlander G.JH. Von Willebrand factor and development of diabetic nephropathy in insulindependent diabetes mellitus. Diaberes 1991:40:971-6.

22. Broze GJ, Miletich JP. Characterization of the inhibition of tissue factor in serum. Blood 1987;69:150-5.

23. Werling RW, Zacharski LR, Kisiel W, Bajaj SP, Memoli VA, Rousseau SM. Distribution of tissue factor pathway inhibitor in normal and malignant human tissues. Thromb Haemost 1993:69:366-9.

24. Bajaj MS, Kuppuswamy MN, Saito H, Spitzer SG, Bajaj SP. Cultured normal human hepatocytes do not synthesize lipoprotein-associated coagulation inhibitor: evidence that endothelium is the principle site of its synthesis. Proc Natl Acad Sci USA $1990 ; 87: 8869-73$.

25. Sandset PM, Abildgaard U, Larsen ML. Heparin induces release of extrinsic coagulation pathway inhibitor (EPI). Throm Res 1988:50:803-13.

26. Novony WF, Girard TJ, Miletich JP, Broze GJ. Purification and characterization of the lipoprotein-associated coagulation inhibitor from human plasma. I Biol Chem $1989 ; 264: 18832-7$.

27. Lesnik P, Vonica A, Guerin M, Moreau M, Chapman MJ. Anticoagulant activity of tissue factor pathway inhibitor in human plasma is preferentially associated with dense subspecies of LDL and HDL and with Lp(a). Arterioscler Thromb $1993 ; 13: 1066-75$.

28. Lindahl AK, Sandset PM. Abildgaard U. The present status of tissue factor pathway inhibitor. Blood Coagul Fibrinolysis 1992;3:439-49.

29. Carmassi F, Morale M, Pucceti R, De Negri F, Monzani F, Navalesi R, Mariani G. Coagulation and fibrinolytic system imparment in insulin-dependent diabetes mellitus. Thromb Res 1992;67:643-54. 
30. Kario K, Matsuo T, Kobayashi H, Matsuo M, Sakata T, Miyata T. Activation of tissue factor-induced coagulation and endothelial cell dysfunction in non-insulindependent diabetic patients with microabuminuria. Arterioscler Thromb vase Biol 1995:15:1114-20. 


\section{Chapter 2}

\section{Tissue Factor Pathway Inhibitor (TFPI) in physiologic and pathologic conditions}

PB Leurs, R van Oerle, BHR Wolffenbuttel, K Hamulyák 


\section{Introduction}

It was not until 1987 that an important protein was identified as a new Kunitz-type coagulation inhibitor'. It was a logical consequence of intense research in the years before, which focused on a factor, apparently circulating in the plasma, that exerted an inhibitory action on coagulation, initiated by the tissue factor pathway. This factor was first named anticonvertin ${ }^{2}$. Later the name varied from lipoprotein associated coagulation inhibitor (LACI) to extrinsic pathway inhibitor (EPI) ${ }^{1,3.4}$. Eventually, to unify the nomenclature, a concensus meeting in 1991 of the Scientific and Standardization Committee of the International Society on Thrombosis and Haemostasis agreed on the name tissue factor pathway inhibitor (TFPI).

The TFPI protein consists of 276 amino acid residues, with a molecular weight of $42 \mathrm{kDa}$, with a negatively charged acidlic amino-terminal end, three tandemly repeated Kunitz type inhibitory domains and a positively charged basic carboxyterminal end (Figure 2.1$)^{5}$. More recently, a second human TFPI molecule, with 32 $\mathrm{kDa}$ of molecular weight containing 213 amino acids, has been isolated, which weakly inhibits factor $\mathrm{Xa}$, but with a strong inhibitory effect on the factor VIla/tissue factor complex ${ }^{6}$.

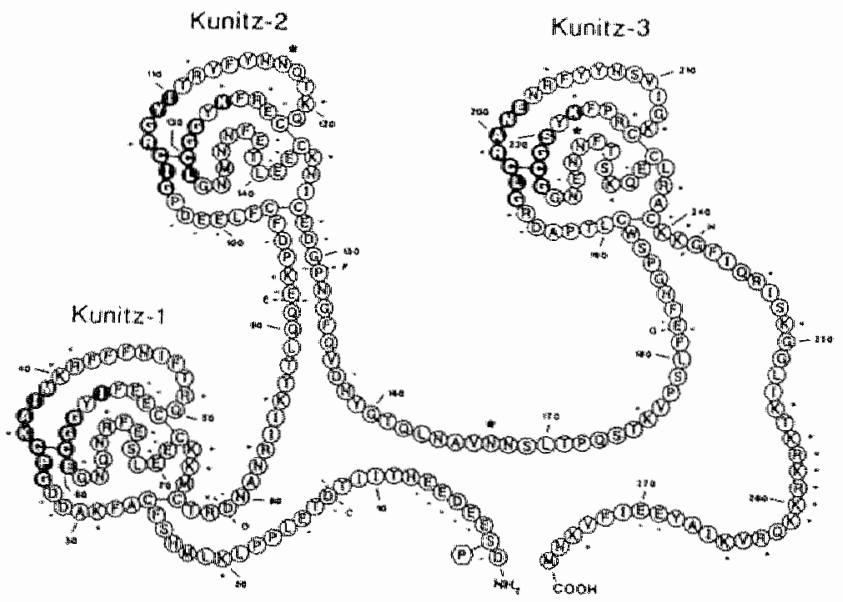

Figure 2.1 The TFPl protein contains 276 amino acid residues, with a negatively charged acidic aminu-terminal end, the tandemly repeated Kunita type inhibitory domains and a possitively charged basic carboxy-terminal end. The 18 Cys residues in TFPI

The nonthrombogenic properties of the endothelial cell surface are maintained partly by protease inhibitors of the coagulation cascade. TFPI plays as a natural anticoagulant a key regulatory role in tissue factor-initiated blood coagulation. 
Firsty, it directly inhibits factor $X a$ by a calcium-independent binding of the second Kunitz domain to factor $\mathrm{Xa}$ (Figure 2.2)? Then, a calcium-dependent binding of the first Kunitz domain of the TFPI molecule to factor Vlla inhibits the factor VIla/tissuc factor catalytic complex. The formation of a quarternary complex occurs ather via the binding of a TFPU/factor Xa complex to the factor VIIa/tissue factor complex or via binding of TFPI to the factor Xa/factor VIla/ tissue factor complex ${ }^{7-10}$. Endothelial cell-associated TFPI may therefore play an important role in the anticoagulant property of endothelial cells.

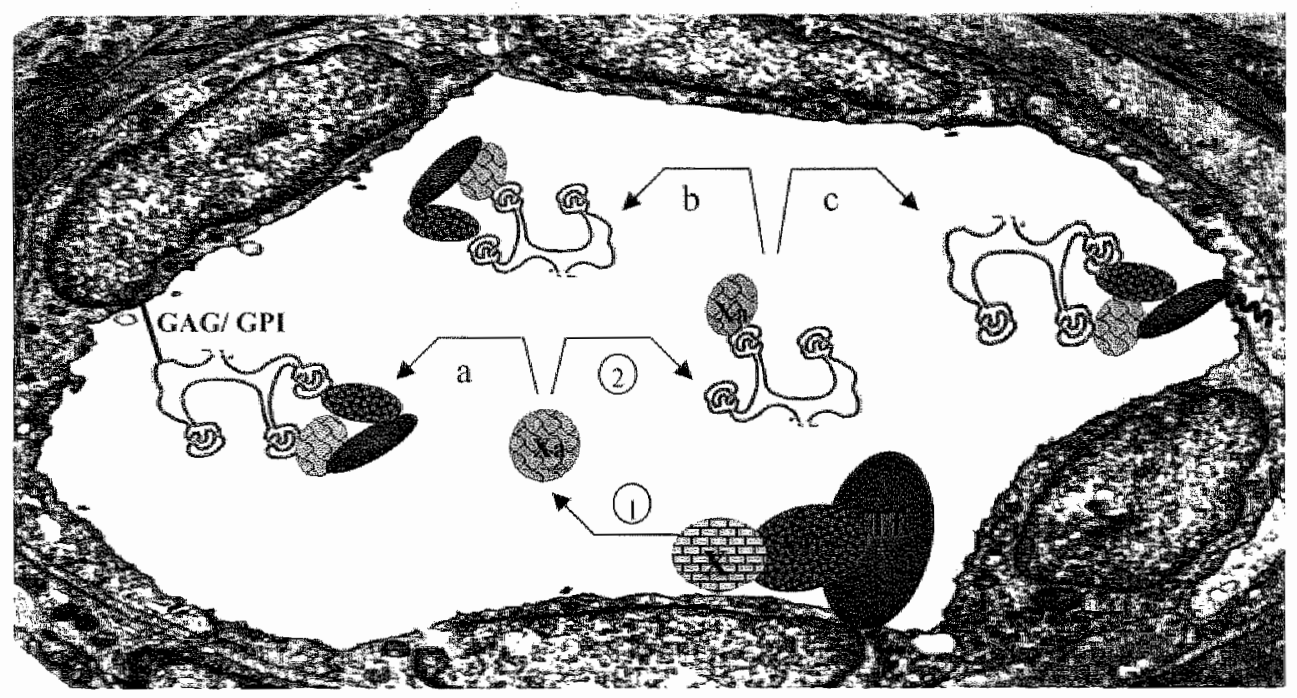

Figure 2.2 Anticoagulant properties of TFPI. After conversion of factor $X$ lo $X_{a}$ by (transmembrane) glycoprotein tissue factor (TF) and lactor Vllat (1). TFPI is able to inhibit this tactor $X_{a}$ by binding factor $X_{a}$ to Kaniz domain 2 (2). This first step in the two-step reaction mechanism is $\mathrm{Ca}^{2+}$ independent. In the second step TFPl exerts it anti TFVIla activity by binding of the tactor Xa/TFPI complex to the TFVila complex. Hereby fator Vula is bound the Kunitz domain 1 of TFPl in a calcium-dependent way. Three major ways for formation of this guateruary complex can be distinguished [7-10]: TFPVIXa complex is bound to TF/VIL

a. whereby TFPI is bound the endothelial cell surface by gyecsaminoglycans (GAG) and or glycosyl phosphatidylinosion (GPI).

b. firee in plasma.

c. whereby TF is anchored in the plasma membrane. 


\section{Synthesis of TFPI}

Under normal physiologic conditions, the synthesis and expression of TFPI is restricted to megakaryocytes and the endothelial cells of the microvasculature ${ }^{11.12}$. TFPI can also be found in macrophages in the villi of term placenta ${ }^{11}$. Increased levels of TFPI are commonly found in pregnancy ${ }^{13}$. More recently, TFPI expression has also been demonstrated in vascular smooth muscle cells ${ }^{14.15}$.

The gene for TFPl is located on chromosome $2 \mathrm{q}$ and contains nine exons ${ }^{16-18}$. Exon 1 and 2 comprise the 5'untranslated region of TFPI mRNA. Exon 3 encodes for the signal peptide and $\mathrm{NH}_{2}$-terminal head region of the TFPI protein. Exons 4, 6 and 8 encode for the Kunitz domains 1, 2, and 3, respectively. Exon 5 encodes for the linker region between domains 1 and 2, exon 7 encodes for the linker region between domains 2 and 3. Exon 9 encodes for the $\mathrm{COOH}$-terminal tail region of the TFPI molecule. The TFPI gene containes GATA motifs which may regulate its expression by a GATA-2 transciption factor, which is produced by endothelial cells ${ }^{19}$. Recently, potential regulatory elements of the TFPI promotor region have been identified ${ }^{20}$.

After synthesis, the TFPI proteins are stored in well-defined cytoplasmatic granules (caveolae), evenly spread over the cell surface of resting endothelial cells ${ }^{21,22}$.

\section{Binding of TFPI to endothelial cells}

It is considered that TFPI molecules are exocytosed towards the surface of the endothelial cells, where it remains anchored probably to glycosaminoglycans, e.g. heparan sulfate ${ }^{21.23 \cdot 26}$. The specific binding to glycosaminoglycans requires the highly positively charged carboxy-terminal end of the TFPI molecule, a binding of electrostatic nature ${ }^{27}$. It seems that TFPI is bound to the endothelial cell surface in a saturable manner ${ }^{26,2 k}$. Another region located in the third Kunitz domain binds to glycosaminoglycans like heparin with low-affinity ${ }^{29}$. However, not all studies indicate the involvement of glycosaminoglycans in the binding of TFPI to endothelial cells ${ }^{30}$. In addition to endothelial glycosaminoglycans, others have demonstrated glycosyl phosphatidylinositol (GPI)-anchored binding sites for TFPI molecules at the cell surface ${ }^{22.3 !}$. It is speculated that TFPI at GPI-anchored binding sites reflects heparin-unreleasable TFPI. On the other hand, TFPI bound to endothelial glycosaminoglycans, can be easily released by other glycosaminoglycans such as heparin ${ }^{23}$. Repeated intravenous injections and continuous intravenous infusion of heparin leads to a considerable depletion of heparin releasable TFPI ${ }^{28}$. Depending on the assay used, the release of TFPI after heparin results in a $2-4$ fold increase in TFPI activity ${ }^{23.32}, 3-10$ fold increase in total TFPI antigen levels ${ }^{32.33}$, and $8-15$ fold increase in free TFPI antigen levels ${ }^{28}$. 


\section{TFPI in plasma}

TFPI, bound to the endothelial cell surface, comprises the major pool $(50-80 \%)$ of 3 intravascular pools, in which TFPI can be found. In plasma, the second pool, $10-50 \%$ of TFPI is located, while platelets serve as the third pool, containing only a fraction of total TFPl ${ }^{34}$. The physiological plasma concentration of TFPI is about $100 \mathrm{ng} / \mathrm{ml}$ or $2.5 \mathrm{mmol} / \mathrm{l}$, but is increasing with age ${ }^{33.35}$. Most of TFPI in plasma is associated with lipoproteins $\mathrm{LDL}, \mathrm{HDL}$ and $\mathrm{LP}(\mathrm{a})^{36-38}$. The major form of TFPI associated with LDL is $34 \mathrm{kDa}$, whereas that associated with HDL is about $41 \mathrm{kDa}$. It is suggested that the carboxy-terminal end of TFPI is involved in the interaction between TFPI and lipoproteins ${ }^{39}$. However, this is contradicted by the finding that TFPI, bound to LDL, lacks a substantial portion of the carboxyterminal end, including at least a portion of the third Kunitz domain ${ }^{38}$. The C-terminus of TFPI is essential for its anticoagulant activity 40.41 . It is therefore not surprising that only a weak anticoagulant activity of lipoprotein associated TFPI can be demonstrated ${ }^{3,42-44}$. On the other hand, free uncomplexed TFPI, which consists $5-10 \%$ of total TFPI in plasma, exerts a strong anticoagulant activity ${ }^{3,4}$. This free portion of TFPI is inversely correlated with $\mathrm{HDL}^{45}$.

The heparin-releasable TFPI is almost entirely carrier-free and it is known to contribute significantly to the anticoagulant action of heparins s3.46.47. $^{4}$.

\section{Degradation and clearance of TFPI}

Until now, little is known about the degradation and clearance of TFPI in humans. From pharmacokinetic studies in rabbits it is known that the clearance of recombinant TFPI exhibited a bi-exponential elimination with a rapid $\alpha$ phase hall life of $2.3 \mathrm{~min}$, due to a rapid redistribution and tissue uptake, especially in the liver and kidney (outer cortex), and a terminal 13 phase half-life of $79 \mathrm{~min}^{4 *}$. The half-life of full-length TFPI is markedly shorter than of TFPI truncated at the carboxy-terminus ${ }^{40}$. The rapid hepatic and renal clearance of TFPI stimulated others to look for specific receptors, which mediated the uptake into tissues. It was found that in rat and human hepatoma cell lines TFPI cellular degradation, but not binding to the cell, is mediated by low density lipoprotein receptor-related protein (LRP), a cell-surface glycoprotein that functions as a hepatic endocytosis receptor for several plasma proteins ${ }^{50.51}$. It appears that the LRP-mediated clearance of TFPI occurs in two steps. In the initial step, which requires the presence of the $\mathrm{C}$-terminus and can be inhibited by heparin, TFPI binds to an unrelated cell-surface receptor, possibly glycosaminoglycans, before it is presented to LRP for uptake and degradation, presumably by endocytosis ${ }^{5 n-s z}$. In contrast, others could not demonstrate a degradation of exogenously added TFPI by human umbilical vein 
endothelial cells (HUVEC), although it was bound to the cell surface ${ }^{53}$. Because of the presence of endogenous TFPI in endocytic and recycling comparments of HUVEC, it is hypothesized that endogenous, membrane-anchored TFPI could be internalized for subsequent recycling back to the cell surface ${ }^{53}$.

Cell surface glycosaminoglycans like heparan sulfate associated with endothelial cells have been proposed to play a role in the clearance of TFPI $^{23}$. More recently, a study in mice suggested the involvement of two independent receptor systems in the clearance of TFPI, i.e. LRP and heparan sulfate proteoglycan ${ }^{54}$. Underlining the role of glycosaminoglycans in the clearance of TFPI, it appears that heparan sulfate proteoglycans are required for uptake and degradation of TFPI-factor Xa complexes, while factor $\mathrm{Xa}$ binding stimulates the internalization and degradation of cell surface-bound TFPI ${ }^{10.5 s}$. Another study also provided evidence for a dual role of factor $\mathrm{Xa}^{36}$. Besides its role as an essential cofactor in the TFPI-controlled regulation of tissue factor-dependent coagulation, it was shown that factor Xa cleavage of TFPI is associated with loss of anticoagulant activity. A novel degradation pathway of TFPI is demonstrated by Ohkura et al. ${ }^{57}$ Hereby, TFPI is incorporated into fibrin clots via interaction of basic amino acid residues in the C-terminal region of TFPI with negatively charged residues in fibrin. Thereafter, TFPI is degraded by fibrin-bound thrombin, probably by cleaving peptide bonds in the TFPI molecule.

More recently, proteolysis of rTFPI by plasmin is demonstrated, suggesting that TFPI is susceptible to proteolysis when the plasma fibrinolytic system is activated $^{5 s}$.

\section{TFPI in pathologic conditions}

When the tissue factor pathway is activated by exposure of blood to tissue factor at an imjury site the coagulation cascade is initiated by the formation of the factor VIla-tissue factor catalytic complex. This complex has the ability to activate factor IX into IXa and factor $X$ into $X a$ by proteolysis ${ }^{59}$. This eventually leads to the generation of thrombin and the formation of a fibrin clot. In addition, endothelial cells and monocyles are the predominant cells that may express tissue factor during an inflammatory disease. It is demonstrated that HUVEC are capable to express tissue factor in reponse to various stimuli, known to be important during inflammation ${ }^{6,3}$. However, while expression of tissue factor was markedly tumor necrosis factor- $\alpha$, TFPI secretion into the endotoxin, interleukin- 1 and slightly higher in induced HUVEC cultures ${ }^{4}$. The media was unchanged or only synthesis is not downregulated, but maltures ${ }^{(44}$. These data indicate that TFPI infammatory response ${ }^{\text {ta }}$. Factor $\mathrm{Xa}$ binding be slightly upregulated during an 
of cell surface-bound TFPI' ${ }^{10}$. On the other hand, it has recenily been shown that upon treatment of cultured endothelial cells with thrombin, a marked redistribution and acute release of TFPI occurred from specific granules ${ }^{21}$

Disseminated intravascular coagulation (DIC) appears to be related to vascular endothelial cell injury because plasma levels of endothelial-dependent hemostatic parameters, i.e. thrombomodulin, tissue type plasminogen activator (t-PA), plasminogen activator inhibitor-1 (PAI-1), and von Willebrand factor (vWF) are shown to be increased in $D \mathrm{IC}^{65.65}$. Tissue factor is a major initiator of the onset of DIC $^{67.68}$. It appeared that TFPI and tissue factor both were increased in DIC, but tissue factor did not correlate with TFPI ${ }^{69}$. More recently, it is demonstrated that TFPI, following an increase in tissue factor, is increased in patients with DIC, suggesting that TFPI may reflect vascular endothelial damage ${ }^{\text {\% }}$. An earlier report suggested no increase of TFPI in DIC in patients with hepatocellular disease ${ }^{78}$. Lower TFPI levels have been found in cirrhotic patients ${ }^{12.72}$. It is thereby postulated that the decrease in TFPI may be due to decreased levels of LDL cholesterol secondary to hepatocellular dysfunction.

Systemic coagulation activation is a well-recognized feature of malignancy, partly because tumor cells produce factors which directly and indirectly could induce coagulation activation ${ }^{73-75}$. Increased TFPI activity is also found in cancer patients ${ }^{42}$. It is postulated that this increase could result from the production of host cells, possibly endothelial cells stimulated by cytokines from the malignant process, or from products of hypercoagulation ${ }^{42}$. Later, others demonstrated that tumorassociated macrophages in several types of malignancy, which are known to express a complete tissue factor-initiated pathway of coagulation and thrombin generation, also express TFPI ${ }^{11}$. By contrast, malignant cells, known to express coagulation factors together with tumor cell-associated fibrin formation failed to stain immunohistochemically for TFPI". These results may indicate that TFPI may be lacking from the latter malignancies because of the absence of tissue factor/factor VIla-factor/Xa complex, required for TFPI binding.

Decreased plasma TFPI activity have been found in patients with ischemic stroke, while no relationship could be established between TFPI activity and other haemostatic parameters reflecting procoaculant activity ${ }^{76}$. Therefore, the moderately lower TFPI activity in stroke patients could be due to atherosclerotic changes rather than to consumptive coagulopathy ${ }^{76}$. In contrast, elevated plasma TFPI activity has been demonstrated in patients with acute coronary disease, in whom a moderate increase in procoagulant activity (factor VIll-phospholipid complex) was also seen, suggesting that TFPI adapts to procoagulant changes ${ }^{77}$. However, no relation between factor VII and TFPI activity was found by others, but, instead, a close association between TFPI and plasma levels of dense LDL and small, dense HDL particles was shown ${ }^{7 x}$. Recently, Petit et al. showed in an in vitro experiment that the procoagulant activity of tissue factor in macrophage-derived foam cells is not 
counterbalanced by upregulation of TFPI activity ${ }^{79}$. Some have suggested that the increased TFPI after acute myocardial infarction might be released from ischemic tissue $e^{* i}$. The observation of a severe depletion of heparin-releasable TFPI in patients undergoing percutaneous transluminal coronary angioplasty could be of importance, considering the acute thrombotic occlusion which may occur following this procedure ${ }^{81}$. This observation was later confirmed by a study, in which depletion of intravascular pools of TFPI was demonstrated during continuous intravenous infusion of heparin in healthy volunteers ${ }^{28}$. Also in patients suffering from ischemic heart disease like unstable or effort angina elevated TFPI levels have been observed ${ }^{8.8 *}$. It was thereby suggested that the blood clotting activation in these patients may be related to elevated tissue factor circulating levels not sufficiently inhibited by the elevated TFPI plasma levels. Recently, it is suggested that TFPI exon IX polymorphism may be associated with subtypes of myocardial infarctions ${ }^{\text {s.d }}$. On the other hand, TFPI has been demonstrated in human carotid atherosclerotic plaques, which was associated with a reduced tissue factor activity within the plaque ${ }^{85}$. Others found increased heparin-releasable TFPI levels in the coronary circulation after coronary spasm in patients with coronary spastic angina ${ }^{\text {Ho }}$. Recently, increased expression of TFPI in atherosclerotic vessels has been demonstrated ${ }^{\text {k7 }}$.

In dyslipemic patients, TFPI activity may vary, depending on the variations of its main lipoprotein carriers $^{88}$. In general, TFPI activity is increased in hypercholesterolemic patients ${ }^{89}$, although decreased levels of carrier-free TFPI in hyperlipidemic subjects have also been found ${ }^{90}$. Treatment of patients with familial hypercholesterolemia with hydroxymethylglutaryl-coenzyme A reductase inhibitors resulted in a marked decrease of TFPI activity, with a close correlation with corresponding alterations in LDL levels ${ }^{\mathrm{kg}}$. It appears that the effect of cholesterol lowering on the intravascular pools of TFPI does not affect the size or the anticoagulant potency of the endothelial pool of TFPI ${ }^{43}$. A daily dosage of $3 \mathrm{~g} \mathrm{n}^{-3}$ polyunsaturated fatty acids in patients with chronic atherosclerotic disease resulted in a significant but small increase of TFPI plasma levels, which was correlated with increased LDL levels ${ }^{91}$. Simultaneously, a significant reduction of $F_{1+2}$ levels with no changes in plasma factor VII clotting activity was shown, indicating a down-regulation of the extrinsic pathway of blood coagulation. However, others did not find any effect of n-3 fatty acids on plasma factor VII and TFPI ${ }^{92}$. Monounsaturated-rich diet has been demonstrated to induce a decrease in plasma levels of TFPI and other endothelium-derived factors in young healthy males, suggesting a beneficial effect on endothelial function ${ }^{93}$. In plasma of hypercholesterolemic monkeys on a high-cholesterol diet an increase in
LDL/VLDL-associated TFPI was postheparin TFPI between normal seen, while there was no difference in suggested that the results reflect and hypercholesterolemic animals ${ }^{94}$. It was suggested that the results reflect a decrease of TFPI on endothelial cells in 
atherosclerotic \esions.

It is becoming increasingly clear that the oxidative modification of LDL cholesterol underlies the atherogenicity of these cholesterol-rich particles ${ }^{95}$. st $^{\text {. Recently, it is }}$ demonstrated that TFPI activity, associated with LDL is inactivated by cell and copper mediated oxidation ${ }^{97}$. This oxidative inactivation of LDL-associated TFPI may therefore effectively neutralize its inhibitory action on tissue factor activity, resulting in a disequilibrium in favor of coagulation, especially in the atheromatous plaque, where tissue factor is overexpressed.

Finally, there are two other groups of patients, in which altered TFPI levels may suggest vascular endothelial damage, i.e. patients with thrombotic thrombocytopenic purpura and in hemodialysis patients ${ }^{98.100}$. In addition, high levels of TFPI were found in patients with nephrotic proteinuria ${ }^{101}$. In renal biopsies of patients with crescentic glomerulonephritis, the expression of TFPI was increased, suggesting that TFPI may inhibit tissue factor activity and favor reduced fibrin deposition in the chronic stages of crescent formation ${ }^{102}$. Also in adult respiratory distress syndrome and interstitial lung disease increased levels of TFPI are reported, possibly due to synthesis of TFPI by the lung epithelial lining cells and/or endothelial cells of the microvasculature ${ }^{103.104}$.

Recently, in women taking combined oral contraceptives a decrease in plasma TFPI has been demonstrated, suggesting a possible explanation for the thrombotic effect of oral contraceptives ${ }^{105}$.

\section{Potential therapeutic applications of TFPI}

With the development of recombinant TFPI (rTFPI) it became possible to explore the usefunness of TFPI as a therapeutic agent. In animal studies, using rabbits, it was shown that rTFPI ameliorated the consequences of DIC induced by tissue thromboplastin or endotoxin ${ }^{106,107}$. In baboons, rTFPI reduced the mortality of septic shock caused by Escherichia coli, while in pigs TFPI treatment only resulted in an attenuation of mediators of the inflammatory response, but did not provide survival benefit ${ }^{\text {ifs. }} .109$

Recombinant TFPI is also used 10 prevent thrombosis in conditions, in which a beneficial effect of rTFPI can be expected because of exposure to tissue factor ${ }^{110}$. Increased levels of TFPI are found in healthy subjects, using elastic stockings during upright passive tilting"I. It is thereby suggested that TFPI may represent a possible mechanism by which prophylaxis of deep vein thrombosis with the use of elastic stockings can be explained. In vein bypass grafting procedures it appeared that rTFPI is able to prevent thromosis effectively ${ }^{1 / 2}$. Besides, rTFPI is shown to prevent restenosis after thrombolysis and balloon-induced anterial injury, possibly by attenuation of procoagulant activity and tissue factor-mediated thrombin 
generation in response to injury $13+116$. In vitro, rTFPI can also reduce the thrombogenicity of disrupted human atherosclerotic plaques by inhibition of tissue factor $^{17}$. Recombinant TFPI is probably also an effective agent in limiting postoperative paraplegia associated with spinal ischemia combined with ischemia/reperfusion injury in rabbits ${ }^{18}$. In rats, rTFPI strongly inhibits the injury of ischemic reperfusion of the liver after clamping the hepatic artery and portal vein for 2 to 3 hours" ${ }^{14 \%}$. In vivo TFPI gene transfer into an injured artery completely inhibits the recurrent thrombosis induced by shear stress without affecting the systemic coagulation status in rabbits and pigs ${ }^{120,121}$.

In rats, exogenous TFPI can increase anticoagulant activity on the hepatic sinusoidal walls by binding to heparinoids on the cell surface ${ }^{122}$.

In man, no studies have yet been performed with rTFPI, but the animal studies thusfar are promising for TTFPI as a therapeutic mean in the near future. 


\section{References}

1. Broze GI, Miletich IP. Characterization of the inhibition of tissue factor in serum. Blood 1987;69:150-5.

2. Hjort PF. Intermediate reactions in the coagulation of blood with thromboplastin. Scan J Clin Lab Invest 1957:9 (S27):1-173.

3. Rao LVM, Rapaport SI. Studies of a mechanism inhibiting the initiation of the extrinsic pathway of coagulation. Blood 1987;69:645-51.

4. Sandset PM, Abildgaard U, Pettersen M. A sensitive assay of exirinsic coagulation pathway inhibitor (EPI) in plasma and plasma fractions. Thromb Res 1987:47. $389-400$.

5. Wun TC, Kretzmer KK, Girard TJ, Miletich JP, Broze GJ. Cloning and characterization of a cDNA coding for lipoprotein-associated coagulation inhubitor shows that it consists of three tandem Kunitz-type inhibitory domains. I Biol Chem 1988;263:6001-4.

6. Sprecher CA, Kisiel W, Mathewes S, Foster DC. Molecular cloning, expression. and partial characterizarion of a second human tissue factor pathway inhibitot. Proc Natl Acad Sci USA 1994;91:3353-7.

7. Girard TJ, Warren LA, Novotny WF, Likert KM, Brown SG, Miletich JP, Broze G. Functional significance of the Kunitz type inhibitor domains of lipoproteinassociated coagulation imhibitor. Nature 1989:338:518-20.

8. Broze Gll. Tissue factor pathway inhibitor. Thromb Haemost 1995;74:90-3.

9. Iakhiaev A, Pendurthi UR, Voigt J, Ezban M, Rao LVM. Catabolism of factor VIla bound to tissue factor in fibroblasts in the present and absence of tissue factor pathway inhibitor. J Biol Chem 199;274:36995 7003 .

10. Ho G, Toomey JR, Broze GJ, Schwartz AL. Receptor-mediated endocytosis of coagulation factor Xa requires cell surface-bound tissue factor pathway inhibitor. I Biol Chem 1996;271:9497-502.

11. Werling RW, Zacharski LR, Kisiel W, Bajaj SP, Memoli VA, Rousseau SM. Distribution of tissue factor pathway inhibitor in normal and malignant human tissues. Thromb Haemost 1993;69:366-9.

12. Bajaj MS, Kuppuswamy MN, Saito H, Spitzer SG, Bajaj SP. Cultured normal human hepatocytes do not synthesize lipoproten-associated coagulation inhibitor: evidence that endothelium is the principle site of its synthesis. Proc Natl Acad Sci USA $1990 ; 87 ; 8869-73$.

13. Sandset PM, Hellgren $M$, Uvebrandt $M$, Bergström H. Extrinsic coagulation pathway inhbitor and heparin cofactor II during normal and hypertensive pregnancy. Thromb Res 1989;55:665-70.

14. Caplice NM. Mueske CS, Kleppe LS, Peterson TE, Broze GJ Ir, Simari RD. Expression of tissue factor pathway inhibitor in vascular smooth muscle cells and is regulation by growth factors. Circ Res 1998;83:1264-70.

15. Pendurthi UR, Rao LV, Williams JT, Idell S. Regulation of tissue factor pathway inhibitor expression in smooth muscle cells. Blood 1999,94:579-86. 
16. Van der logt CPE, Reisma PH, Bertina RM. Intron-exon organization of the human gene coding for the lipoprotein-associated coagulation inhibior. The factor Xa dependent unhibitor of the extrinsic pathway of coagulation. Biochemistry 1991:30: 1571.7.

17. Girard TJ, Eddy R, Wesselschmidt RL, MacPhail LA, Likert KM, Byers MG, Shows TB, Broze GJ. Structure of the human lipoprotein-associated coagulation inhibitor gene, J Biol Chem 1991;266:503641.

18. Envoji Kl, Emi M, Mukai T, Imada M, Leppert ML, Lalouel $\mathbb{M}$, Kato H. Human tissue factor inhibitor (TFPI) gene: complete genomic structure and localization on the genetic map of chromosome $2 q$. Genomics $1993 ; 17: 423-8$.

19. Tyson DR, Kuppuswamy MN, Broze GJ, Bajaj SP. Revised DNA sequence of exon 1 and 5 " flanking region of the human tissue factor pathway inhibitor gene. Thromb Res $1993 ; 70: 269-73$.

20. Petit L, Lesnik P. Dachet C. Hugou I, Moreau M, Chapman J, Rouis M. The promotor of human tissue factor pathway inhibitor gene: identification of potential regulatory elements. Thromb Res 1999:95:255-62.

21. Lupu C, Lupu F, Demnehy U, Kakkar VV, Scully MF. Thrombin induces the redistribution and acute release of lissue factor pathway nhibitor from specific granules within human endothelial cells in culture. Arterioscler Thromb Vasc Biol $1995 ; 15: 2055 \sim 62$.

22. Lupu C, Goodwin CA, Westmucket AD, Emeis JJ, Scully MF, Kakkar VV, Lupu F. Tissue factor pathway inhibitor in endothelial cells colocalizes with glycolipid microdomains/caveolae. Arterioscler Thromb Vasc Biol 1997; 17:2964-74.

23. Sandset PM, Abildgard U, Larsen ML. Heparin induces release of extrinsic Coagulation pathway inhibitor (EPI). Throm Res 1988;50:803-13.

24. Kojima T, Katsumi A, Yamazaki T, Muramatsu T, Nagasaka T, Ohsumi K, Saito H. Human ryudocan from endothelium-like cells binds basic fibroblast growth factor, midkine, and tissue factor pathway inhibitor. J Biol Chem 1996;271: $5914-20$.

25. Ho, $\mathrm{G}$ Broze GJ. Schwartz AL. Role of heparan sulfate proteoglycans in the uptake and degradation of lissue factor pathway inhibitor-coagulation factor Xa complexes. J Biol Chem 1997:272:16838 44.

26. Hine C, Enjyoji $\mathrm{K}$. Kamikubo $\mathrm{Y}$, Kato $\mathrm{H}$. Two distinct binding sites for tissue factor pathway inhibitor on endothelial cells. Thromb Haemost 1997; Abstract PS-
$1657: 406$.

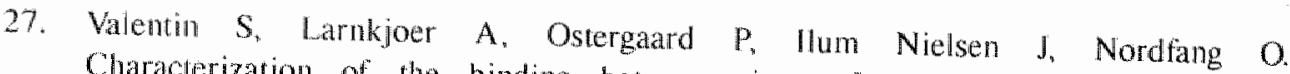
Characterization of the binding between tissue factor pathway inhibitor and glycosaminoglycarts. Thromb Res 1994;75:173-83.

28. Hansen JB, Sandset PM. Huseby KR, Huseby NE, Nordoy A. Depletion of intravascular pools of tissue factor pathway inhibitor (TFPI) during repeated or 1996:76:703-9. 
29. Wesselschmidt $R$, Likert $K$, Huang ZF. MacPhail L. Broze GI. Structural requirements for tissue factor pathway inhibitor interactions win factor Xa and heparin. Blood Coagul Fibrinol 1993;4:661-9.

30. Iversen N, Sandset PM, Abildgaard U. Torjesen PA. Binding of tissue factor pathway inhibitor to cultured endothelial cells: influence of glycosaminoglycans. Thromb Res 1996;84:267-78.

31. Sevinsky JR, Rao LVM, Ruf W. Ligand-induced protease receptor translocation into caveolae: a mechanism for regulating cell surface proteolysis of the tissue factor-dependent coagulation pathway. J Cell Biol 1996:133:293 304.

32. Hubbard AR, Weller LI, Gray E. Measurement of tissue factor pathway inhibitor in normal and postheparin plasma. Blood Coagul Fibrinol 1994:5:819-23.

33. Novotny WF, Brown SG, Miletich IP, Rader DJ, Broze GJ. Plasma antigen levels of the lipoprotem-associated coagulation imhibitor in patient samples. Blood 1991; 78:387-93.

34. Sandset PM, Abildgaard U. Extrinsic coaguation inhibitor: the key to feedback control of blood coagulation iniliated by tissue thromboplastin. Haemostasis $1991: 21: 219-39$.

35. Sandset PM, Larsen ML, Abildgaard U, Lindahl AK, Odegaard OR. Chromogenic substrate assay of extrinsic pathway inhibitor (EPI): levels in the normal population and relation to cholesterol. Blood Coagul Fibrinol 1991;2:425-33.

36. Nowotny WF, Girard TJ, Miletich JP. Broze GIl. Purification and characterization of the lipoprotein-associated coagulation inhibitor from human plasma. J Biol Chem $1989 ; 264: 18832-7$.

37. Lesnik P, Vonica A, Guerin M, Moreau M, Chapman MJ. Anticoagulant activity of tissue factor pathway inhibitor in human plasma is preferentially associated with dense subspecies of LDL and HDL and with Lp(a). Arterioscler Thromb 1993; 13:1066-75.

38. Broze GJ, Lange GW, Duffin KL, MacPhail L. Heterogeneity of plasma tissue factor pathway inhibitor. Blood Coagul Fibrinol 1994;5:551-9.

39. Valentin $S$, Nordfang $O$, Bregengard $C$, Wildgoose $P$. Evidence that the $C$ terminus of tissue factor pathway inhibitor (TFPI) is essential for its in vitro and in vivo interaction with lipoprotens. Blood Coagul Fibrinol 1993;4:713-20.

40. Wesselschmidt R, Likert KM, Girard TJ, Wun TC, Broze GJ. Tissue factor pathway inhibitor: the carboxy-terminus is required for optimal inhibition of factor Xa. Blood 1992;79:2004-10.

41. Nordfang O, Biorn SE, Valentin S, Nielsen LS, Wildgoose P. Beck TC, Hedner U. The C-terminus of vissue factor pathway inhibitor is essential to its anticoagulant activity. Biochemistry 1993;30:10371-6.

42. Lindahl AK, Jacobsen PB, Sandset PM. Abildgaard U. Tissue factor pathway inhibitor with high anticoagulant activity is increased in postheparin plasma and in plasma from cancer patients. Blood Codgul Fibrinol 1991:2:713-21. 
43. Hansen JB, Huseby KR. Huseby NE, Sandset PM, Hansen TA, Nordoy A. Effect of cholesterol lowering on intramvascular pools of TFPI and its anticoagulant potential in type II hyperlipoproteinemia. Arterioscler Thromb Vasc Biol 1995;15: 879-85.

44. Hansen IB, Huseby KR, Huseby NE, Eaban M. Nordoy A. Tissue factor pathway inhibitor in complex with low density lipoprotein isolated from human plasma does not possess anticoagulant function in tissue factor-induced coagulation in vitro. Thromb Res 1997;85:413-25.

45. Kawaguchi A, Miyao $Y$, Noguchi $T$, Nonogi $H$, Yamagishi $M$, Miyatake $K$. Kamikubo $\mathrm{Y}$, Kumeda $\mathrm{K}$. Tsushima $M$, Yamamoto $A$, kato $H$. Intravascular free tissue factor pathway inhibitor is inversely correlated with HDL cholesterol and postheparin lipoprotein lipase but proportional to apoliporpotein A-II. Arterioscler Thromb Vasc Biol 2000;20:251-8.

46. Nowotny WF Palmier M, Wun TC, Broze GI, Miletich JP. Purification and properties of heparin releasable lipoprotein-associated coagulation inhibitor. Blood $1991 ; 78: 394-400$.

47. Lindah $\mathrm{AK}$, Abildgaard $\mathrm{U}$, Staalesen $\mathrm{R}$. The anticoagulant effect in heparinized blood and plasma resulting from interactions with extrinsic pathway inhibitor. Thromb Res 1991;64:155 68.

48. Palmier MO, Hall LJ, Reisch CM, Baldwin MK, Wilson AGE, Wun TC. Clearance of recombinant tissue factor pathway imhibiror (TFPI) in rabbits. Thromb Haemost $1992 ; 68: 33-6$.

49. Bregengaard $C$, Nordfang $O$, Ostergaard P, Petersen JGL, Meyn G, Diness $V$, Svendsen $O$, Hedner U. Pharmacokinetics of full-length and two-domain tissue factor pathway inhibitor in combination with heparin in rabbits. Thromb Haemost $1993 ; 70: 454-7$.

50. Warshawsky 1, Broze GJ, Schwartz AL. The low densily lipoprotein receptor. related protein mediates the cellular degradation of tissue factor pathway inhibitor.
Proc Natl Acad Sci USA 1994:91:6664-8.

51. Warshawsky 1, Herz J, Broze Gl, Schwartz AL. The low density lipoprotein receptor-related protein can function independently from heparan sulfate proteoglycans in tissue factor pathway inhibior endocytosis. I Biol Chem 1996; $271: 25873-9$.

52. Warshawsky I, Bu G, Mast A, Saffitz JE, Broze GJ, Schwartz AL. The carboxyterminus of tissue factor pathwy inhibitor is required for interacting with
hepatoma cells in vitro and in vivo. J Clin Invest 1995;95: 1773-81.

53. Hansen IB, Olsen R, Webster P. Association of tissue factor pathway inhibitor with human umbilical vein endothelial cells. Blood 1997;90:3568-78.

54. Narita M, Bu G, Olins GM, Higuchi DA. Herz J, Broze GJ, Schwartz AL. Two receptor systems are inwolved in the plasma clearance of tissue factor pathway
inhibitor in vivo. J Biol Chem $1995,270: 24800-4$.

55. Ho G, Broze GJ, Schwartz. AL. Role of heparan sulfate proteoglycans in the uptake and degradation of tissue factor pathway inhibitor-coagulation factor Xa complexes. 
56. Salemink 1, Franssen J. Willems GM, Hemker HC. Li A, Wun "TC, Lindhou 'T. Factor Xa cleavage of tissue factor pathway inhibitor is associated with loss of anticoagulant activity. Thromb Haemost 1998;80:273-80.

57. Ohkura N, Enjyoji K. Kamikubo Y, Kato H. A novel degradation pathway of tissue factor pathway inhibitor: incorporation into fbrin clot and degradation by thombin. Blood 1997;90:1883-92.

58. Li A, Wun TC. Proteolysis of tissue factor pathway inhibitor by plasmin. effect on TFPI activity. Thromb Haemost 1998;80:423-7.

59. Osterud $\mathrm{B}_{*}$ Rapaport SI. Activation of factor $\mathrm{IX}$ by the reaction product of tissue factor and factor VII: additional pathway for initiating blood coagulation. Proc natl Acad Sci USA 1977;74:5260-5.

60. Colluci M, Balconi G, Lorenzet R, Pietra A, Locati D. Cultured human endothelial cells generate tissue factor in response to endotoxin. J Clin lmest 1983;71:1893-6.

61. Brox JH, Osterud B, Bjorklid E, Fenton JW. Production and availability of thromboplastin in endothelial cells: the effects of thrombin, endotoxin and platelets. Br J Haematol 1984;57:239-46.

62. Bevilacque HP, Pober IS, Majeau GR, Cotran RS, Gimbrone MA. Interleukin I (IL-1) induces biosynthesis and cell surface expression of procoagulant activity in human vascular endothelial cells cultured with endothelial cell growth factor and heparin. J Exp Med 1984;160:618-23.

63. Bevilacque HP, Pober IS, Majeau GR, Fiers W, Cotran RS, Gimbrone MA. Recombinant tumor necrosis factor induces procoagulant activity in cultured human vascular endothelium: characterization and comparison with the actions of interleukin-1. Proc Natl Acad Sci USA 1986;83:4533-7.

64. Ameri A, Kuppuswamy MN, Basu S, Bajaj SP. Expression of tissue factor pathway inhibitor by cultured endothelial cells in response to inflammatory mediators. Blood 1992;79:3219-26.

65. Wada H, Ohiwa M, Kaneko T, Tamaki S, Tanigawa M, Shirakawa S, Koyama M, Hayashi T, Suzuki K. Plasma thrombomodulin as a marker of vascular disorders in thrombotic thrombocytopenic purpura and disseminated intravascular coagulation. Am J Hematol 1992;39:20-4.

66. Wada H, Minamikawa K. Wakita T, Nakase "T, Ohiwa M. Tamaki S, Deguchi K. Shirakawa $S$, Hayashi T, Suzuki $K$. Increased vascular endothelial cell markers in patients with disseminated intravascular coagulation. Am J Hematol 1993;44;85-8.

67. Wada H, Nagano T, Tomeoku M, Kuto M., Karitani Y, Deguchi K, Shirakawa S. Coagulant and fibrinolytic activities in the leukemic cell lysates. Thromb Res 1982 ; 30:315-22.

68. Wada H, Nakase T, Nakaya R, Mnamikawa K, Wakila $Y$, Kaneko T, Ohiwa M, Deguchi K, Shirakawa s. Elewated plasma tissue factor antigen level in patients with disseminated intravsacular coagulation. Am J Hematol 1994;45:232-6.

69. Takahashi H, Sato N, Shibata A. Plasma tissue factor pathway inhibitor in disseminated intravascular coagulation: comparison of its behaviour with plasma tissue factor. Thromb Res 1995;80:339-48. 
70. Shimura $M$, Wada $H$, Wakita $Y$, Nakase $T$, Hiyovama $K$, Nagaya $S$, Mori $Y$, Shiku H. Plasma tissue factor and tissue factor pathway inhibitor levels in patients with disseminated intravascular coagulation. Am J Hematol 1997;55:169-74.

71. Warr TA, Rao LVM. Rapaport S1. Human plasma extrinsic pathway inhibitor activity: II. Plasma levels in disseminated intravascular coagulation and hepatocellular disease. Blood 1989:74:994:8.

72. Okksüzoglu G, Simsek $H$, Haznedaroglu IC, Kirazli S. Tissue factor parthway inhibitor concentrations in cirrhotic patients with and without portal vein thrombosis. Am J Gastroenterol 1997;92:303-6.

73. Zacharski LR, Memoli VA, Costantini V, Wojtukiewicz MZ, Ornstein DL. Clotting factors in tumor tissue: implications for cancer therapy. Blood Coagul Fibrinol $1990 ; 1: 71-8$.

74. Wojtukiewicz MZ, Zacharski LR, Memoli VA, Kisiel W, Kudryk BJ, Rousseau SM, Stump DC. Abnormal regulation of coagulation/fibrinolysis in small cell carcinoma of the lung. Cancer 1990;65:481-5.

75. Ornstein D, Zacharski LR, Memoli VA, Kisiel W, Kudryk BJ, Hunt J, Rousseau SM, Siump DC. Co-existent macrophage procoagulant and tumor cell plasminogen activator in adenocarcinoma and squamous cell carcinoma of the lung. Cancer $1991 ; 68: 1061-7$.

76. Abumiya $T$, Yamaguchi $T$, Terasaki $T$, Kokawa $T$, Kario $K$, Kato $H$. Decreased plasma tissue factor pathway inhibitor activity in ischemic stroke patients. Thromb Haemostas 1995; 74:1050-4.

77. Sandset PM, Sirnes PA, Abildgaard U. Factor VII and extrinsic pathway inhiobitor in acute coronary disease. Br J Haemotol 1989;72:391-6.

78. Moor E, Hamsten A, Karpe F, Båvenholm P, Blombäck M, Silveira A. Relation-ship of tissue factor pathway inhibitor activity to plasma lipoproteins and nyocardial infarction at a young age. Thromb Haemostas 1994;71:707-12.

79. Petit L, Lesnik P, Dachet C, Moreau M, Chapman MJ. Tissue factor pathway inhibitor is expressed by human monocyte-derived macrophages: relationship to tissue factor induction by cholesterol and oxidized LDL. Arterioscler Thromb Vasc Biol 1999: 19:309-15.

80. Kamikura $Y$, Wada H, Yamadia A, Shimura M, Hiyoyama K, Shiku H, Tanigawa M. Nishikawa $H$, Yamada $N$, Isaka $N$, Nakano $T$, Kumeda $K$, Kato $H$. Increased tissue factor pathway inhibitor in patients with acute myocardial infarction. Am I Hematol 1997:55:183-7.

81. Anderson S, Cohen AT, Melissari E, Scully MS, Kakkar VV. Loss of heparinreleasable tissue factor pathway inhibitor in patients undergoing PTCA. Thromb Haemostas 1995:73:328-9.

82. Falciani M, Gori AM, Fedi S, Chiarugi L, Simonetti I, Dabizzi RP, prisco D, Pepe G. Abbate R, Gensini GF, Neri Serneri GG. Elevated tissue factor and tissue factor pathway inhibitor circulating levels in ischaemic heart disease patients. Thromb
Haemost 1998;79:495-9. 
83. Soejma $H$, Ogawa $H$, Yasue $H$, Kaikita $K$. Nishyana $K$, Misumi $K$. Takazoe $K$. Miya $Y$, Yoshimura $M$, Kugyama K. Nakanura $S$, Tsuji I. Kumeda $K$. Heightened tissue factor associated with tissue factor pathway inhibitor and prognosis in parients with unstable angina. Circulation 1999:8:2908-13.

84. Moati D, Seknadji $P$, Galand C, Poirier O, Fumeron F, Desprez S, Garbarz M. Dhermy D, Arveiler D, Evans A, Luc G, Ruidavets JB, Ollivier V. Hakin $\|_{\text {, }}$ Aumont MC de Prost D. Polymorphisms of tissue factor pathway inhibitor (TFPI) gene in patients with acute coronary syndromes and in healtry subjects: impact of the V264M substitution on plasma levels of TFPl. Arterioscler Thromb Vasc Biol 1999; 19:862-9.

85. Caplice NM, Mueske CS, Kleppe LS, Simari RD. Presence of tissue factor pathway inhibitor in human atherosclerotic plaques is associated with reduced tissue factor activity. Circulation 1998;98: 105 $1-7$.

86. Nishiyama K, Ogawa H, Yasue H Soejima H, Hisumi K, Kugyyama K. Tsuji I. Kumeda K. Heparin-releasable endothelial cell-associated tissue factor pathway inhibitor is increased in the coronary circulation after coronary spasm in patients with corinary spastic angina. Thromb Res 1998;89:137-46.

87. Crawley J, Lupu F, Wesmuckett AD, Severs NJ, Kakkar VV. Lupu C. Expression, localization, and activity of tissue factor pathway inhibitor in normal and atherosclerotic human vessels. Arterioscler Thromb Vasc Biol 2000;20:1362-73.

88. Zitoun D, Bara $\mathbb{L}$. Basdewant A, Samama MM. Levels of hactor Vllic associated with decreased tissue factor pathway inhibitor and increased plasminogen activator inhubitor-1 in dyslipidemias. Arteroscler Thromb Vasc Biol 1996;16:77-81.

89. Sandset PM, Lund $H$, Norseth J, Abildgaard U, Ose L. Treatment with hydroxymethylglutaryl-coenzyme A reductase inhibitors in hypercholesterolemia induces changes in the components of the extrinsic coagulation system. Arterioscler Thromb 1991;11:138-45.

90. Kokawa T, Enjyoji K, Kumeda K, Kamikubo $Y$, Harada-Shiba $M$, Koh $H$, Tsushima M. Yamamoto A. Kato H. Measurement of the free form of TFPl antigen in hyperlipidemia. Relationship between free and endothelial cell-associated forms of TFP1. Arterioscler Thromb Vasc Biol $1996 ; 16: 802-8$.

91. Berrettini M, Parise P, Ricotta S, lorio A. Peirone C, Nenci GG. Increased plasma levels of tissue factor pathway inhibitor (TFPl) after n-3 polyunsaturated fatiy acids supplementation in patients with chronic atherosclerotic disease. Thromb Haenostas $1996: 75: 395-400$.

92. Grund H, Nilsen DW, Hetland O, Mansoor MA. Aarsland T, Woie L. Atherothrombogenic risk modulation by $n-3$ fatty acids was not associated with changes in homocysteine in subjects with combined hyperlipidemia. Thromb Haemost 1999 ; $81: 561-5$.

93. Perez-Jimenez F, Castro P. Lopez-Miranda J, Paz-Rojas E, Blanco A, LopezSegura F, Velasco F, Marin C, Fuentes F, Ordovas IM. Circulating levels of endothelial factors are modulated by dietary monounsaturated fat. Atheroscler 1999; $145: 35:-8$. 
94. Abumiya T, Nakamura $S$, Takenaka A. Takenaka $O$, Yoshikuni $Y$, Miyamoto $S$, Kimura $T$, Enjyoji $K$. Kato $H$. Response of plasma tissue factor pathway inhibitor to diet-induced hypercholesterolemia in crab-eating monkeys. Arterioscler Thromb $1994: 14: 483-8$.

95. Steinberg D, Parthasarathy S. Carew TE, Khoo JC. Witztum JL. Modifications of low-density lipoprotein that increase its atherogenicity. $\mathrm{N}$ Engl I Med 1989; $320: 915-24$.

96. Witzum JL. Role of oxidized low-density lipoprotein in atherogenesis. Br Heart J $1993 ; 69: 512-58$.

97. Lesnik P. Dentan C, Vonica A, Moreau M, Chapman MJ. Tissue factor pathway inhibitor activity associated with LDL is inactivated by cell-and copper-mediated oxidation. Arterioscler Thromb Vasc Biol 1995:15:1121-30.

98. Kobayashi M, Wada H, Wakita Y, Shimura M, Nakase T, Hiyoyama K, Nagaya $S$, Minami N, Nakano $T$, Shiku H. Decreased plasma tissue factor pathway inhibitor levels in patients with thrombotic thrombocytopenic purpura. Thromb Haemost $1995 ; 73: 10-4$.

99. Kario K. Matsuo $T$, Yamada $T_{0}$ Matsuo M. Increased tissue factor pathway inhibitor levels in uremic patients on regular hemodialysis. Thromb Haemostas $1994 ; 71: 275-9$.

100. Cardigan RA, McGloin H, Mackie IJ, Machin SJ, Singer M. Activation of the tissue factor pathway occurs during continuous venowenous hemofiltration. Kidney Int $1999 ; 55: 1568-74$.

101. Ariens RA, Moia M, Rivolta E, Ponticelli C, Mannucei PM. High levels of lissue factor pathway inhibitor in patients with nephrotic proteinuria. Thromb Haemost $1999: 82: 1020-23$.

102. Cunningham MA, Ono T, Hewitson TD, Tipping $P G$, becker GJ, Holdsworth SR. Tissue factor parthway inhibitor expression in human crescentic glomerulonephritis. Kidney lint 1999;55:1311-8.

103. Sabharwal AK, Bajaj SP, Ameri A, Tricomo SM. Hyers TM, Dahms TE, Taylor FB. Bajaj MS. Tissue factor pathway inhibitor and von Willebrand factor antigen levels in adult respiratory stress syndrome and in a primate model of sepsis. Am I Respir Crit Care Med 1995; 151:758-67.

104. Cella O. Cipriani A. Tommasini A, Rampin E, Sbarai A, Rocconi R, Mazzaro G. Luzzatto $G$. Tissue factor pathway inhibitor antigen plasma levels in patients with interstitial lung disease before and after heparin administration. Sem Thromb
Hemostas 1997:23:45-9.

105. Harris GM, Stendt CL, Vollenhoven BI, Gan TE, Tipping PG. Decreased plasma issue factor pathway inhibitor in women taking oral contraceptives. Am J Hemato!
$1999.60: 175-80$.

106. Day KC. Hofman LC, Palmier MO, Kretzmer KK. Huang MD, Pyla EY, Spokas E. Broze GJ, Warren TG, Wun TC. Recombinant lipoprotein-associated coagulation rabbit. Blood 1990; $76: 1538-45$. 
107. Bregengaard $C$, Nordfang $O$, Wildgoose $P$, Swendsen $O$, Hedner $U$, Diness $V$. The effect of two-domain tissue factor pathway inhibitor on endotoxin-induced disseminated intravascular coagulation in rabbits. Blood Coagul Fbrinol 1993; 4:699-706.

108. Creasy AA, Chang ACK, Feigen L, Wun TC, Taylor FB. Hinshaw LB. Tissue factor pathway inhibitor reduces mortality from Escherichia coli septic shock. 』Clin Imvest 1993;91:2850-60.

109. Goldfarb RD, Glock D, Johnson K, Creasey AA, Carr C, McCarthy RI, Matushek M. Akhter $\mathbb{~}$, Trenholme G, Parrillo JE. Randomized, blinded, placebo-controlled trial of tissue factor pathway inhibitor in porcine septic shock. Shock 1998; 10: 258-64.

110. Spokes EG, Wun TC. Venous thrombosis produced in the vena cava of rabbits by vascular damage and stasis. IMP 1992;27:225-32.

111. Arcelus JI, Caprini JA, Hoffman KN, Traverso CI, Hoppensteadt D. Fareed J. Modifications of plasma lewels of tissue factor pathway inhibitor and endothelinm 1 induced by a reverse Trendelenburg position: inffuence of elastic compression. I Vasc Surg 1995;22:568-72.

112. Rapp JH, Pan XM, Ghermay A. Gazetas P, Brady SE, Reilly LM. A blinded trial of local recombinant tissue factor pathway inhibitor versus either local or sytemic heparin in a vein bypass model. I Vasc Surg 1997;25:726-9.

113. Haskel EK, Torr SR, Day KC, Palmier MO, Wun TC, Sobel BE, Abendschein DR. Prevention of arterial reocclusion after thrombolysis with recombinant liporpoteinassociated coagulation inhibitor. Circulation 1991;84:821-7.

114. Oltrona L, Speidel CM, Recchia D, Wickline SA, Eisenberg PR, Abendschein DR. Inhibition of tissue factor-mediated coagulation markedly attenuates stenosis after balloon-induced arterial injury in minipigs. Circulation 1997;96:646-52.

15. St Pierre J, Yang LY, Tamirisa K, Scherrer D, De Ciechi P. Eisenberg P, Tolunay E. Abendschein D. Tissue factor pathway inhibitor attenuates procoagulant activity and upregulation of tissue factor at the site of balloon-induced arterial injury in pigs. Arterioscler Thromb Vasc Biol 1999;19:2263-8.

116. Asada $Y$, Hara $S$, Tsuneyoshi A, Hatakeyama $K$. Kisanuki A, Marutsuka K, Sato Y, Kamikubo Y, Sumiyoshi A. Fibrin-rich and platelet-rich thrombus formation on neointima: recombinant tissue factor pathway inhibitor prevents fibrin formation and neointimal development following repeated balloon injury of rabbit aorta. Thromb Haemost 1998;80:506-11.

17. Badimon J, Lettino M, Toschi V. Fuster V, Berrozpe M, Chesebro JH, Badimon L. Local inhibition of tissue factor reduces the thrombogenicity of disrupted human atherosclerotic plaques: effects of tissue factor pathway inhibitor on plaque thrombogenicity under fow conditions. Circulation 1999; 13:1780-7.

118. Koudsi B, Yu CD, Ferguson EW Ir, Miller GA, Merkel KD, Wun TC, Kratemer BA. Prevention of spinal cord injury after transient aortic clamping with lissue factor pathway inhibitor. Surgery 1996;119:269-74. 
19. Yoshimura W, Kobayashi $Y$, Nakamura $K$, Yamagishi $H$, Oka T. The effect of tissue factor pathway inhibitor on hepatic ischemic reperfusion injury of the rat. Transplantation 1999:67:45-53.

120. Nishida T, Ueno H, Atsuchi $N$, Kawano R, Asada $Y$, Nakahara $Y$, Kamikubo $Y$, Takeshita A. Yasui H. Adenovinus-mediated local expression of human tissue factor pathway inhibitor eliminates shear stress-induced recurrent thrombosis in the injured carotid artery of the rabbit. Circ Res 1999;84:1446-52.

121. Zoldhelyi P, McNati J Shelat HS, Yamamoto $Y$, Chen ZQ, Willerson JT. Thromboresistance of balloon-injured porcine carotid arteries after local gene transfer of human tissue factor pathway inhibitor. Circulation 2000; 101:289-95.

122. Yamanobe F, Mochida S, Ohno A, Ishikawa K. Fujiwara K. Recombinant human ussue factor pathway inhibitor as a possible anticoagulant targeting hepatic sinusoidal walls. Thromb Res 1997;85:493-501. 


\section{Chapter 3}

\section{Tissue Factor Pathway Inhibitor (TFPI) activity in patients with IDDM}

PB Leurs, R van Oerle, K Hamulyák, BHR Wolffenbuttel

Diabetes 1995,44:80-4 


\begin{abstract}
Until now, several endothelium-dependent hemostatic parameters have been proposed as markers of vascular endothelial dysfunction in diabetes. We studied tissue factor pathway inhibitor (TFPI) activity in IDDM patients without macroand microvascular complications, before and after intravenous administration of heparin, in comparison with age-matched controls. We also examined the effect of acute hyperglycemia on TFPI activity in healthy men. A clotting and chromogenic assay were used for determining TFPI activity. In the clotting assay the C-terminus of TFPI is essential, while this region is of minor importance in the chromogenic assay. When the chromogenic assay was used, TFPI activity before heparin injection was significantly higher in the IDDM patients $(92 \pm 24$ vs $112 \pm 23 \%$, $p<0.01)$. The postheparin increase in TFPI activity, measured with both assays, was significantly higher in the diabetic subjects (area under the curve: clotting assay $64 \pm 14$ vs $81 \pm 24, \quad \mathrm{p}<0.05$; chromogenic assay $82 \pm 26$ vs $121 \pm 35$. $\mathrm{p}<0.0001)$. A positive correlation between TFPI activity and glycated hemoglobin was demonstrated. Acute hyperglycemia did not alter TFPI activity. It is concluded that TFPI activity, especially after stimulation with heparin, is affected by chronic hyperglycemia in diabetic subjects without vascular complications. Alterations in TFPI activity may therefore reflect early endothelial dysfunction.
\end{abstract}




\section{Introduction}

Diabetes mellitus is associated with premature atherosclerosis. It is known that endothelial cells play an important role in the repair process of vascular injury. thereby maintaining the functional integrity of the vascular wall. Endothelial damage thas been considered as one of the initiating events in the pathogenesis of atherosclerosis'.

The vascular endothelium can be regarded as a paracrine organ which regulates hemostasis (coagulation and fibrinolysis). It produces procoagulant substances (e.g. von Willebrand factor, tissue factor) and components of the fibrinolytic system that promote or inhibit fibrinolysis (tissue plasminogen activator (t-PA) and plasminogen activator inhibitor-1 (PAI-1), respectively) $)^{2.3}$. Endothelium also expresses factors associated. with anticoagulant properties such as heparan sulphate and thrombomodulin ${ }^{2.3}$. In 1987 a new Kunitz-type coagulation inhibitor, tissue factor pathway inhibitor (TFPI), was identified as a single protein ${ }^{4}$. Coagulation activity, initiated by the tissue factor pathway, is activated by the complex of tissue factor and factor VIla. This complex not only activares factor $X$ but factor IX via the Josso loop as well ${ }^{5.6}$. TFPI directly inhibits factor Xa and in complex with factor Xa also the tissue factor/factor VIla catalytic complex?. The major site of production of TFPI is the vascular endothelium ${ }^{5}$. Of TFPI, $50-90 \%$ is found on the endothelium, $10-50 \%$ in plasma and the remainder in platelets ${ }^{9}$. Most of TFPI in the plasma is associated with lipoproteins ${ }^{10.11}$. Only about $5 \%$ of the TFPI in the plasma circulates as a free, uncomplexed protein". TFPI activity is altered in several pathologicall conditions ${ }^{12-14}$. Its release from the endothelium can be stimulated by heparin ${ }^{15}$.

In diabetic patients with microvascular complications increased levels of von Willebrand factor, thrombomodulin, I-PA and PAl-1 are found ${ }^{10.1 \%}$. It is therefore suggested that these alterations in endothelium-dependent hemostatic parameters reflect vascular endothelial damage. Little is known about TFPI activity in diabetic subjects. Because TFPI may also be regarded as a marker of endothelial dysfunction, we studied TFPI activity in IDDM patients without vascular complications before and after intravenous administration of heparin. The effect of acute hyperglycemia on TFPI activity was investigated in healthy men. We also examined the relationship between the degree of metabolic regulation and TFPI activity.

\section{Materials and Methods}

Twenty-five IDDM patients (12 men, 13 women; mean age 33 (range 19-49) years) and 21 age-matched healthy controls (10 men, 11 women; mean age 33 (range 
22-43) years) were studied. Only IDDM subjects without neuropathy, retinopathy, nephropathy and macrovascular complications were included. Thus, all patients were normoalbuminuric and normotensive. Patients were also divided according to the degree of metabolic control. The characteristics of the subjects are depicted in Table 3.1.

Table 3.I Demographic and laboratory parameters of $\mathbb{D} D D M$ patients and controls at biseline.

\begin{tabular}{|c|c|c|c|c|}
\hline & \multirow{2}{*}{$\begin{array}{c}\text { Contirols } \\
1 \\
\end{array}$} & \multicolumn{3}{|c|}{ DODM } \\
\hline & & $\begin{array}{c}\text { Overall } \\
\text { II }\end{array}$ & $\begin{array}{c}\mathrm{HbA}_{1 c}<7.4 \% \\
\mathrm{III} \\
\end{array}$ & $\begin{array}{c}\mathrm{HhA}_{1,2} \geq 8.4 \% \\
\text { IN }\end{array}$ \\
\hline$n$ & 21 & 25 & 12 & 13 \\
\hline Sexextio rato & $\|0 M / 1\| \mathrm{F}$ & $12 \mathrm{M} / 13 \mathrm{~F}$ & $6 \mathrm{M} / 6 \mathrm{~F}$ & $6 \mathrm{M} / 7 \mathrm{~F}$ \\
\hline Ade (years) & $33 \pm 6$ & $33+8$ & $35 \pm 7$ & $32 \pm 8$ \\
\hline Durstion diaflectes (youm) & & $9(1-31)$ & $9(1-3)$ & $9(1-21)$ \\
\hline Diswge insulin (lU/dliy) & & $48 \pm 17$ & $43 \pm 15$ & $53 \pm 16$ \\
\hline Burly mass indicx $\left(\mathrm{kg} / \mathrm{m}^{2}\right)$ & $23.7 \pm 21$ & $23.3 \pm 2.5$ & $22.7 \pm 2.8$ & $23.8 \pm 2.0$ \\
\hline Glyuten hatemoglobin ( $(\%)$ & $4.9 \pm 0.4^{\circ}$ & $8.1 \pm 1.6$ & $6.7 \pm 0.58$ & $9.5 \pm 0.9$ \\
\hline 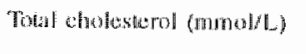 & $50 \pm 0.7$ & $5.3 \pm 1.4$ & $4.9 \pm 0.6$ & $58 \pm 1.7$ \\
\hline Triellycerifes (mmol/L) & $0.87(0.24-2.08)$ & $1.12(0.5-3.56)$ & $0.98(0.5-3.56)$ & $1.12(0.76-1.66)$ \\
\hline HD1.-cholesilerol (mmol/L) & $1.34 \pm 0.33$ & $1.43 \pm 0.42$ & $1.41 \pm 0.45$ & $1.46 \pm 0.40$ \\
\hline LDL chodesteral (mmol/L) & $3.21 \pm 0.63$ & $3.32 \pm 1.46$ & $2.81 \pm 0.67$ & $3.78 \pm 1.78$ \\
\hline Apo $A_{1}(g / L)$ & $1.51 \pm 0.18$ & $1.60 \pm 0.22$ & $1.60 \pm 0.25$ & $1.61 \pm 0.21$ \\
\hline$A$ pro B (B/L) & $0.93 \pm 0.22$ & $1.05 \pm 0.33$ & $0.94 \pm 0.17$ & $1.14 \pm 0.39$ \\
\hline Limeprotein $(\mathrm{a})(\mathrm{O} / \mathrm{L})$ & $139(17+1478)$ & $126(12-1714)$ & $126(21-848)$ & $143(12-1714)$ \\
\hline Serten insulis (pmotil.) & $41.4(19.8-69)$ & $49.2(18-189)$ & $45(22.2+189)$ & $49.2(18.499 .4)$ \\
\hline
\end{tabular}

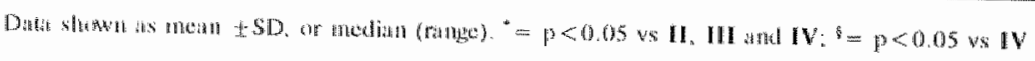

Each study started at $08.00 \mathrm{a}$.m. while the subject was still fasting. With the subject in supine position bloodsamples were taken wia an indwelling catheter in a forearm wein at 15 and 0 minutes before and 3,5,10 and 30 minutes after an intravenous bolus injection of 5000 IU of unfractionated heparin (Leo, Denmark) in the contralateral forearm. For determining TFPI activity, von Willebrand factor, thrombomodulin, t-PA and PAI-1, bloodsamples were collected in tubes containing sodium citrate $3.25 \%$ (dilution $1: 10$ ). Bloodsamples were also drawn for determination of glycated hemoglobin and lipid profile at baseline. Glycated hemoglobin ( $H b A_{1}$ fraction) was measured immediately by a HPLC-method (Diamat, Bio-Rad Laboratories, USA), the remainder of the bloodsamples were centrifuged and plasma was stored at $-70^{\circ} \mathrm{C}$ uncil further processing. 
A second study regarding the effect of an acute glucose load on TFPI activity was performed in 6 healthy men (mean age 30 (range 24-36) years; mean BMI $\left.23.1 \pm 1.4 \mathrm{~kg} / \mathrm{m}^{2}\right)$. After an overnight fast, with the subject in supine position, bloodsamples were taken before and 10 and 30 minutes after intravenous administration of glucose $50 \%(0.5 \mathrm{~g} / \mathrm{kg}$ body weight with a maximum of $35 \mathrm{~g})$ in three minutes time in the contralateral forearm. Bloodsamples for glucose, insulin and $\mathrm{C}$-peptide determinations were also taken. Both protocols were approved by the Ethical Committee of the University Hospital. Written informed consent was obtained from all participants.

TFPI activity was measured using both a modified clotting assay based on the diluted tissue thromboplastin clotting time as reported previously (expressed in seconds; CV $4.5 \%)^{19}$ and the chromogenic substrate assay according to Sandset (expressed in \% with regard to standardized TFPI activity measured in a plasma pool obtained from 45 healthy donors; $\mathrm{CV} 7.4 \%$ at $100 \%$ level ${ }^{20}$. The tissue factor concentration, used in the clotting assay, was adjusted to a coagulation time of 123 seconds measured in normal plasma ${ }^{19}$. With this tissue factor concentration, an optimal balance between accuracy and sensitivity of the clotting assay was achieved. Two different assays were used because with the clotting method mainly full-llength TFPI, which has a very strong bioactivity, is measured, while the chromogenic method also measures C-terminal fragmented TFPI, which has only a weak anticoagulant activity. The area under the curve (AUC) lor TFPI aciivity was also calculated. Plasma levels of von Willebrand factor were determined by an ELISA method using rabbit anti-human von Willebrand factor (Dako $\mathrm{A} / \mathrm{S}$, Denmark; CV 7\%; normal range $60-180 \%$ ). Because of the well-known relation between von Willebrand factor and blood group $\mathrm{O}^{21}$, the blood of the study population was typed. Thrombomodulin determination was performed with an enzyme immunoassay (Diagnostica Stago, France; CV 8-10\%; normal range 50$120 \mathrm{ng} / \mathrm{ml}$, mean $76 \pm 22 \mathrm{ng} / \mathrm{ml})$. An enzyme immunoassay was also used for the measurement of $\mathrm{t}-\mathrm{PA}$ antigen (Innogenetics, Belgium; CV 7\%; normal range 1.3$10.4 \mathrm{ng} / \mathrm{ml}$, mean $4.1 \pm 2.4 \mathrm{ng} / \mathrm{ml})$. PAI-I activity was photometrically measured (Kabi Diagnostica, Sweden; intra-assay CV 0.4-2.4\%; normal range 1-20 AU/ml, median $8 \mathrm{AU} / \mathrm{ml}$ ). Total and HDL-cholesterol and triglycerides were determined with enzymatic colorimetric tests (Unimate 5 and 7, Roche, Basle, Switzerland), and apo $A_{1}$ and apo $B$ were measured with immunoturbidimetry (Uni-kit, Roche). 1..DL-cholesterol was calculated with the Friedewald formula. Lipoprotein (a) was determined by a solid-phase, two-site immunoradiometric assay using two monoclonal antibodies directed towards different epitopes of apo(a) (Pharmacia Diagnostics, Uppsala, Sweden). At a $\mathrm{Lp}$ (a) concentration of $200 \mathrm{U} / \mathrm{L}$ the within-assay coefficient of variation was $4 \%$. An enzymatic hexokinase method (Unimate 5, Roche) was used for measuring serum glucose concentrations. Free serum insulin was measured with a double antibody radioimmunoassay (Pharmacia Diagnostics; 
within-assay $C V \quad 3.4-6.1 \%$ in the range of $18-300 \mathrm{pmol} / \mathrm{L}$ ) after polyethylene glycol pretreatment. C-peptide concentration in serum was also determined by RIA (Byk-Sangtec Diagnostica, Germany; within-assay CV $1.9-5.0 \%$ in the range of $0.10-1.75 \mathrm{nmol} / \mathrm{L})$.

\section{Statistics}

All data are expressed as mean \pm SD or as median and range when not normally distributed. Differences between two group means were tested with a $t$-test. When data were not normally distributed the Mann-Whitney-Wilcoxon rank-sum test was applied. To analyse postheparin TFPI changes a MANOVA for repeated measurements was performed. For comparing more than two groups, one-way analysis of variance with Student-Newman-Keuls correction for multiple comparisons was used. The Kruskal-Wallis analysis of variance was applied if data were not normally distributed.

$P^{p}$-values $\leq 0.05$ were considered statistically significant.

\section{Results}

The IDDM patients and controls were well matched regarding demographic parameters (Table 3.1). There were also no significant differences between the well and poorly - controlled diabetic subjects with respect to duration of diabetes and daily insulin dosage. Lipid profile, $L p(a)$, apo $A_{1}$, apo $B$ and insulin concentrations were similar in the diabetic and control group. There was also no significant correlation between these (apo)lipoproteins or serum insulin levels and the endothelium-dependent indices. Regarding the endothelium-dependent coagulant and fibrinolytic proteins at baseline, plasma levels of thrombonodulin and PAI-1 activity were not different between both study groups (Table 3.2). In contrast, 1-PA anligen was significantly lower $(p<0.01)$ in the diabetic subjects compared to the controls, independently of the degree of metabolic control, while the plasma level of von Willebrand factor was higher $(p<0.01)$. However, levels of 1 -PA antigen and von Willebrand factor in the diabetic patients were still within normal ranges. A significant correlation between $-P A$ and TFPI activity, when measured with the clotting assay, was found $(r=0.56, p<0.01)$. There was no difference in blood groups between the control and diabetic subjects. TFPI activity before administration of heparin was similar in the various groups when it was measured with the clotting assay. 
Table 3.2 Hemostatic parameters of IDDM and healthy subjects at baselne.

\begin{tabular}{|c|c|c|c|c|}
\hline & \multirow{2}{*}{$\begin{array}{l}\text { Controls } \\
1\end{array}$} & \multicolumn{3}{|c|}{ IIODM } \\
\hline & & $\begin{array}{l}\text { Onverall } \\
\text { II }\end{array}$ & $\begin{array}{c}\text { HWA } 10<7.4 \% \\
\text { ID:I }\end{array}$ & $\begin{array}{c}\text { WhAli } 28.4 \% \\
\text { IV }\end{array}$ \\
\hline Won willebrand boner (s) & $84.7 \pm 24.3^{45}$ & $103.5 \pm 218$ & $1090 \pm 223$ & $985 \pm 210$ \\
\hline Thrombourtodulin (ng/mi) & $80.1 \pm 22.7$ & $80.6 \pm+22.3$ & $85.2 \pm 20.5$ & $76,5=23,9$ \\
\hline 1-PA $(n \& m b)$ & $8.77 \pm 2.6 !^{\prime \prime}$ & $6.65 \pm 2.23$ & $6.82 \pm 2.42$ & 6.49 is 2.11 \\
\hline PAI-1 (AU/mI) & $6.9(1.0-25.9)$ & $4.3(1.0116 .00)$ & $5.0(1.0-15.9)$ & $29(1.0-16.0)$ \\
\hline ThPI activity (sec) & $116 \pm 10$ & $116 \pm 11$ & $115 \pm 10$ & $117 \pm 11$ \\
\hline TFPI sciwity (wh & $92 \pm 24^{\circ}$ & $112 \pm 23$ & $10 !+12$ & $122+25^{4}$ \\
\hline
\end{tabular}

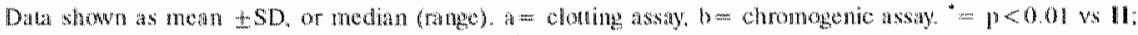

$i=p<0.05$ vs III: $=p<0.05$ vs IIII and IV: $=p<0.05$ vs I and III

In contrast, when measured chromogenically, TFPI activity was significantly higher $(\mathrm{p}<0.01)$ in the diabetic group at baseline. In poorly controlled patients, TFPI activity was higher $(\mathrm{p}<0.05)$ than in well-controlled subjects (Figure 3.1$)$.

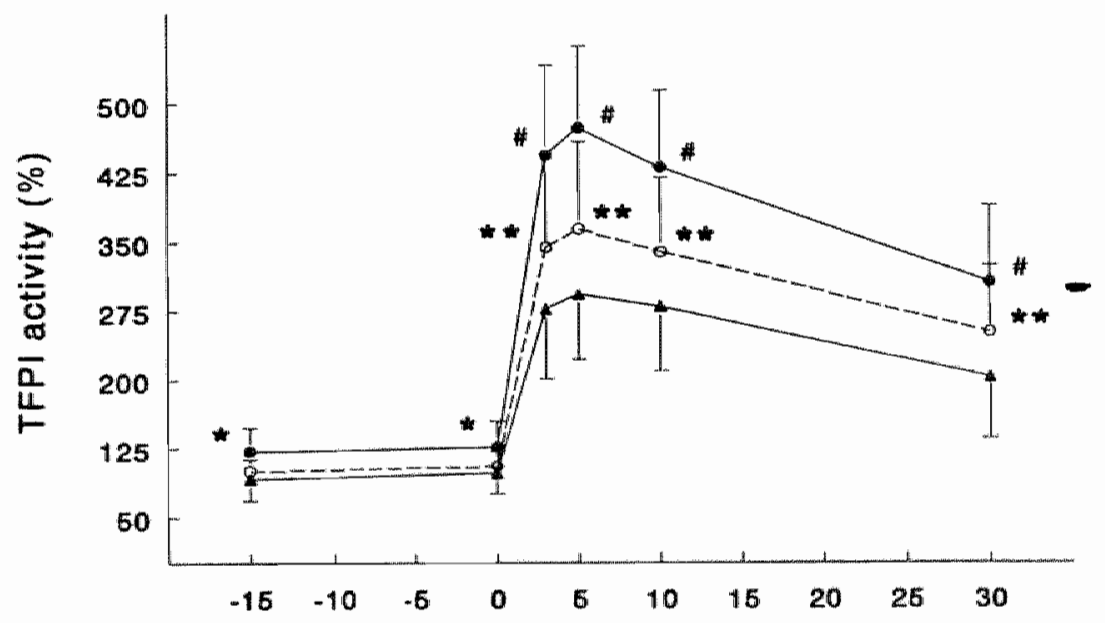

Minutes

Figure 3.1 The increment of TFPI activity neasured chromogenically, after $i . y$ bolus irjection of 5000 IU off heparin in well $(0 ; n=12)$ and puorly $(\bullet ; n=13)$ regulated IDDM patients and healthy controls $(4 ; n=21)$. Betore admintstration of heparin, TFPI activity is significartly higher in the poorly regulated patients $=$ $p<0.05$ vs well regulated group, $p<0.01$ w controls). The difference in increase in postheparin actiwity is already significant 3 minutes after stimulation $(\#=$ $p<0.05$ vs well regulated group, $p<0.0001$ ws controls; * $=p<0.05$ vs controls). 
The postheparin TFPI activity in the diabetic subjects was higher than in the controls. The difference in increase of TFPI activity, measured chromogenically, was significant at all time points after intravenous administration of heparin $(p<0.0001)$. When diabetes control was poor, the postheparin increase of TFPI activity was significantly higher than in case of a good metabolic regulation (at 5 min $264 \pm 95 \%$ vs $352 \pm 73 \%, p<0.05$; Figure 3.1 ). The maximum peak in TFPI activity in the IDDM group $(421 \pm 106 \%)$ and controls $(293 \pm 71 \%)$ was seen 5 minutes after heparin administration. A significant correlation was found between $\mathrm{HbA}_{\text {ic }}$ and the AUC of postheparin TFPl activity $(r=0.68, p<0.001$; Figure 3.2). When applying the clotting assay, comparable results were seen. The increase in TFPI activity was significantly higher in the diabetic subjects at 5 to 30 minutes postheparin $(p<0.05)$. There also existed a correlation between the AUC of postheparin TFPI activity and $\mathrm{HbA}_{i c}(\mathrm{r}=0.45, \mathrm{p}<0.001)$.

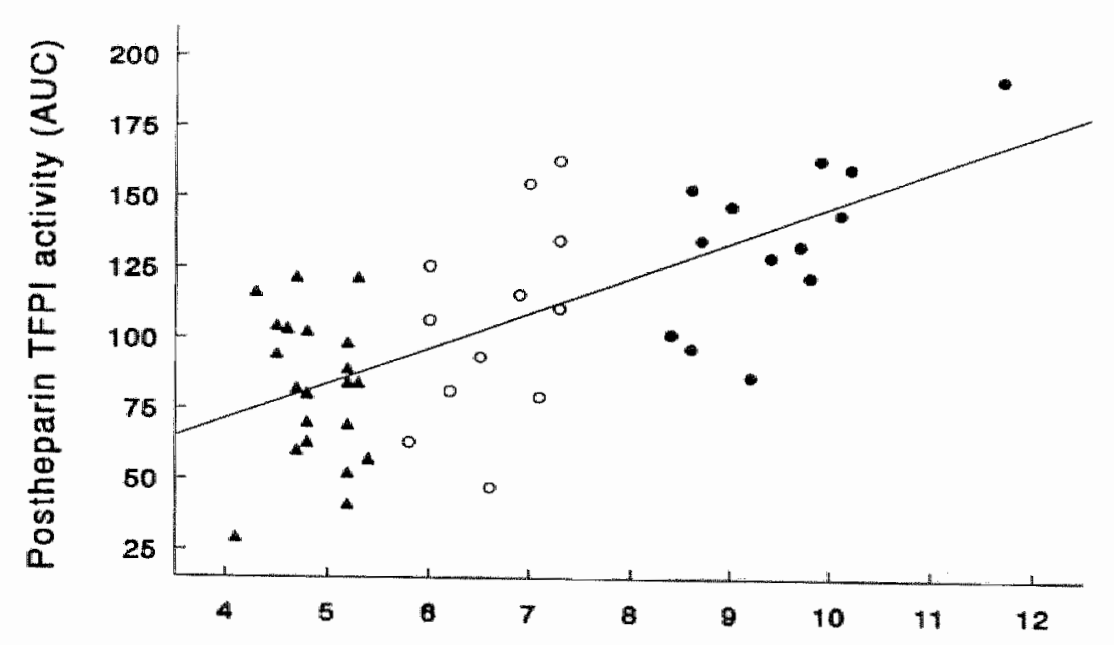

HbA1c (\%)

Figure 3.2 A significant contrelation $(r=0.68, p<0.001)$ is found between the degree of metablic regulation and the AUC of the chromogenically medsured postheparin TFPl activity. When the clotting assay was used. a weaker correlation was found $(n=0.45, p<0.001)$. : healthy controils, 0 : well regulated, : poorly regulated IDDM subjects.

In the second study the mean fasting glucose concentration was $4.2 \pm 0.2 \mathrm{mmol} / \mathrm{L}$ which increased to a maximum of $16.1 \pm 1.4 \mathrm{mmol} / \mathrm{L}$ one minute after intravenous administration of glucose. After 10 and 30 minutes the glucose levels were $11.9 \pm 0.8$ and $7.2 \pm 1.9 \mathrm{mmol} / \mathrm{L}$, respectively (Table 3.3). TFPI activity, measured with both assays, did not change after induction of acute hyperglycemia. 
Table 3.3 Effect of an acute glucose load on TFPl activity in 6 heathy males

\begin{tabular}{|c|c|c|c|}
\hline & $0 \mathrm{rmin}$ & 10 min & 30 mina \\
\hline Glucose (mmalla) & $4.2 \pm 0.3$ & $11.9 \pm 0.8$ & $7.2+19$ \\
\hline Insulin (prow/L) & $29.4(9.6-65.4)^{1}$ & $132(61.6-316.2)$ & $828(58.2-228)$ \\
\hline C-pepplide (namol/L) & $0.77 \pm 0.29^{48}$ & $2.20+10.77$ & $204+070$ \\
\hline TFPl activity (sec) & $125 \pm 6$ & $128 \pm 4$ & $127 \pm 7$ \\
\hline TFPl activily (w) & $115 \pm 18$ & 106418 & $106 \pm 21$ \\
\hline
\end{tabular}

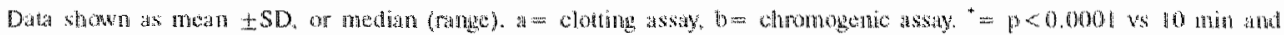

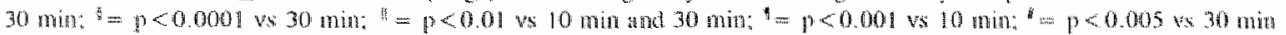

\section{Discussion}

TFPl is regarded as an important protein in the regulation of hemostasis. Besides, TFPI activity may reflect endothelial function because TFPI is produced by and mainly found on vascular endothelium. It is possibly bound to the endothelial cell surface by glycosaminoglycans ${ }^{9}$. The C-terminus of TFPI, which is important for binding glycosaminoglycans like heparin, can be truncated by various enzymes, resulting in considerable loss of its anticoagulant activity ${ }^{22.23}$. In the present study two different assays for determining TFPI activity were used. The modified clotting assay measures the anticoagulant full-length TFPI, while the chromogenic assay also measures $\mathrm{C}$-terminal truncated TFPI. In comparison with healthy controls, a significantly higher increase in TFPI activity after stimulation with heparin was observed in our IDDM subjects. This was true for both assays. When applying the clotting assay, the increase in TFPI activity appeared to be independent of the activity at baseline.

It is well known that in diabetic subjects several hemostatic parameters are disturbed. These include coagulant and fibrinolytic components that, just as TFPI, are dependent on the vascular endothelial cell function ${ }^{24.25}$. Our results indicate that TFPI activity after stimulation with heparin is influenced by the chronic hyperglycemic condition. Not only a higher increase in TFPI activity in the diabetic patients was seen but also a significant positive correlation between postheparin TFPI activity and $\mathrm{HbA}_{\mathrm{ic}}$ was found. No relation between TFPI activity and serum insulin levels could be demonstrated. There was also no effect of acute hyperglycemia on basal TFPI activicy in healthy subjects.

It is known that TFPI has an association with the lipoproteins LDL, HDL and $L p(a)^{16.11}$. In the present study, mean total and LDL-cholesterol and the median of Lp(a) levels tended to be higher in poorly-regulated diabetic patients than in the well-regulated diabetic and control group, but this difference did not reach 
statistical significance. We did not find any correlation between TFPI activity at baseline or postheparin and plasma (apo)lipoproteins.

An important feature of diabetes mellitus is the occurrence of non-enzymatic glycation reactions in which also proteins, important in hemostasis, are involved ${ }^{26}$. The difference in the measurements of TFPI activity between the clotting and chromogenic method, especially at baseline, could be the result of a difference in sensitivity between both assays. However, it may also suggest the presence of fragmented TFPI in diabetic patients. This may be the result of non-enzymatic glycation. Besides, it is thought that TFPI is bound to the endothelial cell surface by glycosaminoglycans. ${ }^{9}$. Heparin is able to release proteins that are bound to glycosaminoglycans, such as platelet factor 4 (PF4), from the endothelium ${ }^{27}$. In diabetic subjects, the release of PF4 after intravenous administration of heparin was significantly higher than in healthy controls $\mathrm{s}^{27}$. Heparin probably also binds to lysine residues as in antithrombin III, resulting in a more rapid reaction with coagulation proteases $^{2 x}$. It has been demonstrated that this heparin colactor activity of antithrombin III is altered by non-enzymatic glycation ${ }^{26}$. As already mentioned, the C-terminus of TFPI, which contains lysine residues, is essential for binding to heparin. We speculate that in diabetes the C-terminus of TFPI is affected by the process of non-enzymatic glycation. This may lead to functional alterations of these molecules resulting in an altered binding between glycosaminoglycans and TFPI, which may be responsible for the excess of release of TFPI in diabetic patients after injection of heparin. An additional explanation may be the non-enzymatic glycation of apolipoproteins $A_{1}$ and $B^{29.30}$. The C-terminus of TFPI thereby appears to be involved in the interaction between TFPI and the lipoproteins ${ }^{31}$. It has been shown that glycation diminishes the interaction between apolipoprotein $A_{1}$ and the HDL particle $^{30}$. If one presumes that this also occurs between the lipoproteins and TFPI, one may expect a redistribution of TFPI in favour of the vascular endolholium. In that case, a higher response in TFPI activity after heparin injection may occur.

Non-enzymatic glycation eventually results in the formation and accumulation of advanced glycation endproducts (AGEs). AGEs are able to affect the endothelial cellular function by interacting with specific receptors, inducing an increase in lissue factor activity and a reduction in thrombomodulin activity ${ }^{32}$. The altered TFPl activity in diabetes may also be related to functional alterations in the endothelium by AGEs.

Increased oxidative stress as seen in diabetes is accompanied by abnormalities in hemostatic paraneters, especially in subjects with microalbuminuria ${ }^{18,33}$. Collier et al. observed elevated levels of von Willebrand factor, t-PA and PAI-1, suggesting that these hemostatic alterations were a result of damage of endothelial cells ${ }^{s 8}$. Since our patients had no secondary complications, the increase in postheparin TFPI activity may be a reflection of early endothelial damage. There was a 
significant difference between our diabetic subjects and controls with respect to von Willebrand factor and t-PA. This is in contrast with earlier reports, most of which suggested that von Willebrand factor and t-PA levels are only changed in diabetic patients with microvascular complications ${ }^{16.18}$. Because the levels of t-PA and von Willebrand factor in our patients were still within normal ranges, the exact significance of these altered levels is not clear. The differences in levels of von Willebrand factor could not be explained by a different distribution of blood group. There was no correlation between TFPI activity and von Willebrand factor. However, a significant correlation between t-PA and TFPI activity, when measured with the clotting assay, existed. The explanation for this finding is unclear, especially since the t-PA levels were significantly lower in the IDDM group in comparison with the controls. Although metabolic control may influence the levels of $t-P A$ and von Willebrand $^{34.35}$, we found no relation between $t-P A$ and von Willebrand factor and $\mathrm{HbA}_{1 \mathrm{c}}$.

In conclusion, postheparin TFPI activity in IDDM patients without secondary complications is significantly increased, and correlates with the degree of metabolic derangement. The explanation for this observation is not yet known, but nonenzymatic glycation and AGE formation may play an important role. However, early damage of endothelial vascular cells as a direct result of hyperglycemia and oxidative stress can not be ruled out. 


\section{References}

1. Ross R, Glomset J, Harker L. Response to injury and atherogenesis. Am J Pathol 1977;86:675 84.

2. Jaffe EA: Endothelial cell structure and function. In Hematology: Basic Principles and Practice. Hoffman R, Benj EJ Jr, Shattil SJ, Furie B, Cohen HJ, Eds. New York, NY, Churchill Livingston 1991:1198-213.

3. Esmon CT, Owen WG. Identification of an endothelial cofactor for thrombincatalyzed activation of protein C. Proc Natl Acad Sci USA 1981;78:2249-52.

4. Broze GJ, Miletich JP. Characterization of the inhibition of tissue factor in serum. Blood 1987;69:150-5.

5. Josso F. Prou-Wartelle O. Interaction of tissue factor and factor VII at the earliest phase of coagulation. Thromb Diath Haemorrh 1965;S17;35-44.

6. Osterud B, Rapaport SI. Activation of factor IX by the reaction product of tissue factor and factor VII: additional pathway for initiating blood coagulation. Proc Natl Acad Sci USA 1977:74:5260-4.

7. Rao LVM, Rapaport SI. Studies of a mechanism inhibiting the initiation of the exrrinsic pathway of coagulation. Blood 1987;69:645-51.

8. Bajaj MS, Kuppuswamy MN, Saito $H$, Spitzer SG, Bajaj SP. Cultured normal human hepatocytes do not synthesize lipoprotein-associated coagulation inhibitor: Evidence that endothelium is the principal site of its synthesis. Proc Natl Acad Sci USA 1990;87:8869-73.

9. Lindahl AK, Sandset PM, Abildgaard U. The present status of tissue factor pathway inhibitor. Blood Coagul Fibrinol 1992;3:439-49.

10. Novotny WF, Girard TJ, Miletich JP, Broze GJ. Purification and characterization of the lipoprotein-associated coagulation inhibitor from human plasma. I Biol Chem 1989;264:18832-7.

11. Lesnik P, Vonica A, Guerin M, Moreau M, Chapman MI. Anticoagulant activity of rissue factor pathway inhibitor in human plasma is preferentially associated with dense subspecies of LDL and HDL and with Lp(a). Atheroscl Thromb 1993:13:1066-75.

12. Lindahl AK, Jacobsen PB, Sandset PM, Abildgaard U. Tissue factor pathway inhibitor with high anticoagulant activity is increased in post-heparin plasma and in plasma fron cancer patients. Blood Coagul Fibrinol 1991;2:713-21.

13. Sandset PM, Sirnes PA, Abildgaard U. Factor VII and extrinsic pathway inhibitor in acute coronary disease. Br J Haematol 1989;72:39 -6.

14. Novolny WF, Brown SG, Miletich JP, Rader DJ, Broze Jr Gi. Plasma antigen levels of the lipoprotein-associated coagulation inhibitor in patient samples. Blood $1991 ; 78: 387-93$.

15. Sandset PM, Abildgaard U, Larsen ML. Heparin induces release of extrinsic pathway inhibitor (EPI). Thromb Res 1988;50:803-13.

16. Jensen $T$, Bjerre-Knudsen J, Feldt-Rasmussen B, Deckert $T$. Features of endothelial dysfunction in early nephropathy. Lancet 1989;i:461-3. 
17. Washma $Y$, Sato $T$, Watanabe $K$, Ooshima $E$, Hiraishi $S$, Ishii $H$, Kazama M, Makino 1. Elevation of plasma thrombomodulin level in diabetic patients with early diabetic nephropathy. Diabetes 1990:39:983-8.

18. Collier A, Rumley A, Rumley AG, Paterson JR, Leach JP, Lowe GDO. Small M. Free radical activity and hemostatic factors in NIDDM parients with and wilhout microalbuminuria. Diabetes 1992;41:909-13.

19. Van Oerle $R$, Leurs PB, Lindhout T, Nordfang $O$, Hamulyăk $K$. The anticoaguland activity of tissue factor pathway inhibitor (TFP) in plasma assessed by an automated assay on an ACL 300R cagulation apparatus (Abstract). Thromb Haemostas 1993;69:2061A.

20. Sandset PM, Abildgaard U, Pettersen M. A sensitive assay of extrinsic coagulation pathway inhibitor (EPI) in plasma and plasma fractions. Thromb Res 1987:47: $389-400$.

21. Tomasulo PA, Richards W, Bailey M, Gajewski M, Aster RH, Lazerson I. Preselection of donors to improve the quality of cryoprecipitate. Am I Hematol 1980:8:191-6.

22. Litske JG, Meyn G, Rasmussen JS, Petersen J, Bjorn SE, Jonassen I, Christiansen L. Nordfang $O$. Characterization of human tissue factor pathway inhibitor (TFPI) variants expressed in Saccharomyces cerevisiae. J Biol Chem 1993;268:13344-51.

23. Nordfang $O$, Valentin $S$. Enzymatic cleavage at the C-terminus of lissue factor pathway inhibitor. Thromb Haemostas 1993;69:250A.

24. Vukovich TC, Schernthaner Gi, Knobi PN, Hay U. The effect of near-normoglycemic control on plasma factor VIII/von Willebrand factor and fibrin degradation products in insulin-dlependent diabetic patients. J Clin Endocrinol Metab 1989;69:84m9.

25. Juhan-Vague I, Alessi $M C_{\text {, }}$ Vague $P$. Increased plasma plasminogen activator inhibitor 1 levels. A possible link between insulin resistance and atherothrombosis. Diabetologia $1991 ; 34: 457-62$.

26. Villanueva GB, Allen N. Demonstration of altered antithrombin III activity due to non-enzymatic glycosylation at glucose concentration expected to be encountered in severely diabetic patients. Diabetes 1988;37:1103-7.

27. O'Brien JR, Etherington MD, Pashley M. Intra-platelet platelet factor 4 (IP.PF4) and the heparin-mobilisable pool of PF4 in health and atherosclerosis. Thromb Haemostas 1984;51:354-7.

28. Nordenman B, Dantelsson A, Bjork I. The binding of low aftinity and high aflinity heparin to antithrombin. Eur J Biochem 1978:90:1-6.

29. Tames FJ. Mackness MI, Arrol S, Laing I, Durrington PN. Non-enzymatic glycation of apolipoprotein $B$ in the sera of diabetic and non-diabetic subjects. Atherosclierosis $1992 ; 93: 237-44$.

30. Calvo $\mathrm{C}$. verdugo $\mathrm{C}$. Association in vivo of glycated apolipoprotein $\mathrm{A}_{\|}$witt high density Iipoproteins. Eur J Clin Chem Clin Biochem 1992;30:3-5.

31. Vallentin $S$, Nordfang $O$, Bregengard $C$, Wildgoose P. Evidence that the C-terminus of tissue factor pathway inhibitor (TFPl) is essential for its in vitro and in vivo interaction with lipoproteins. Blood Coagul Fibrinol 1993;4:713-20. 
32. Esposito C, Gerlach H, Brett J, Stern D, Vlassara H. Endothelial receptor-mediated binding of glucose-modified albumin is associated with increased monolayer permeability and modulation of cell surface coagulant properties. I Exp Med 1989; 170:1387-407.

33. Baynes JW. Role of oxidative stress in development of complications in diabetes. Diabetes 1991:40:405-12.

34. Genzalez J, Colwell A, Sarji KE, Nair RMG, Sagel J. Effect of metabolic control with insulin on plasma von Willebrand factor activity (VIII R:VWF) in diabetes mellitus. Thromb Res 1980;17:261-6.

35. Juhan-Vague I, Vague P, Poisson C. Aillaud MF, Mendez C, Collen D. Effect of 24 hours of normoglycaemia on tissue-type plasminogen activator plasma levels in insulin-dependent diabetes. Thromb Haemostas 1984;51:97-8. 


\section{Chapter 4}

\section{Tissue Factor Pathway Inhibitor (TFPI) release after heparin stimulation is increased in type 1 diabetic patients with albuminuria}

PB Leurs, R van Oerle, K Hamulyák, BHR Wolffenbuttel 


\begin{abstract}
Tissue factor pathway inhibitor (TFPI) is produced by and mainly bound to the vascular endothelium, probably by glycosaminoglycans. Heparin stimulates TFPI release from the endobliclium. In uncomplicated patients with type I diabetes mellitus, we recently demonstrated higher basal and postheparin TFPI activity. In the present study, we investigated whether an increased TFPI activity could be resulted from an altered binding between TFPI and endothelial glycosaminoglycans. Nineteen uncomplicated type 1 diabetic patients (group I) were compared with 18 patients with retinopathy (group II), and 9 patients with retinopathy and albuminuria (group III). Blood samples were taken before (basal) and 30 minutes after 5,000 IU of heparin 4.v. (postheparin). TFPI activity was measured chromogenically. Won Willebrand factor, t-PA, PAI-1 and thrombomodulin were also measured. Basal TFPI activity was higher in group III $(121 \pm 10 \%)$ compared to group $\|(111 \pm 8 \%)$ or group $1(\| 10 \pm 13 \%)(p<0.05)$, and strongly correlated with albuminuria $(r=0.66, p<0.05)$. At all time points after heparin administration, TFPl activity in group III was significantly higher than in group I. TFPI activity was also higher in group III than in group II 5 to 30 minutes postheparin. The increase in postheparin TFPI activity, as measured as the incremental area under the curve, was higher in group III as compared to group $\|(65 \pm 7$ vs. $59 \pm 4 ; p<0.05)$. Of the other parameters, only thrombomodulin was higher in group III (44 \pm 24 vs $26 \pm 7$ (group II) and $28 \pm 9 \mathrm{ng} / \mathrm{ml}$ (group 1); $<<0.01$ ). We conclude that basal and postheparin TFPI activity is increased in albuminuric patients. This suggests that the increase in TFPI activity could be the result of altered endothelial glycosaminoglycan characteristics.
\end{abstract}




\section{Introduction}

One of the main therapeutic goals in diabetes is to prevent or delay the development of macro- and microangiopathy. We therefore need instruments which enable us to estimate the risk of developing vascular complications early in the course of diabetes, so that specific preventive and therapeutic measures can be taken. Since damage of the endothelium precedes angiopathy, several investigators have looked for specific markers of endothelial dysfunction. Only when microvascular complications have already been established, von Willebrand factor (vWF), thrombomodulin, plasminogen activator inhibitor I (PAI-1) and tissue plasminogen activator (t-PA) have been identified as such markers ${ }^{1-3}$. The measurement of urinary albumin excretion is used as a substitute.

Tissue factor pathway inhibitor (TFPI), is produced by and mainly bound to the vascular endothelium ${ }^{4}$. TFPI is a coagulation inhibitor that inhibits factor $\mathrm{Xa}$, and in complex with factor $\mathrm{Xa}$, also the tissue factor/factor VIIa complex. The binding of TFPI to the endothelial cell surface is thought to be established by glycosaminoglycans like heparan sulfate ${ }^{5.6}$. The release of TFPI from the endothelium can be stimulated by heparin, a glycosaminoglycan for which TFPI has a much higher binding affinity than for heparan sulfate, which represents the majority of glycosaminoglycans at the endothelial cell surface ${ }^{5.6}$. We have previously demonstrated higher TFPI activity before and after heparin administration in type 1 diabetic subjects without vascular complications compared to healthy controls? ${ }^{7}$. TFPI activity was strongly related to the degree of long-term metabolic derangement. Acute hyperglycemia did not affect TFPI activity in nondiabetic subjects ${ }^{7}$. Studies with cultured endothelial cells also indicate that chronic hyperglycemia increases release of TFPI after heparin stimulation ${ }^{\not}$. In diabetic subjects with complications, we and others have demonstrated that basal TFPI activity is also increased ${ }^{9.12}$. In addition, it has been shown that basal plasma TFPI activity is increased in patients with manifest macroangiopathy, such as acule coronary disease ${ }^{13.14}$. TFPI activity is also altered in other pathological conditions, which are known to be associated with (micro)vascular abnormalities ${ }^{15}$. We recently showed that the increase in TFPI activity in type I diabetic patients is not the result of a compensatory response to a procoagulant state". Alternatively, because of the binding to glycosaminoglycans, the increase in TFPl activity could be a result of altered functional properties of endothelial glycosaminoglycans, leading to a weaker binding of TFPI to glycosaminoglycans.

Subsequently to our earlier studies, we therefore imestigated the functional relationship between TFPI and glycosaminoglycans by means of stimulation of TFPI release from the endothelium by heparin in type 1 diabetic patients with and without albuminuria. 


\section{Subjects, materials and methods}

Forty-six type 1 diabetic patients were studied and an evaluation with respect to micro- and macrovascular complications (history, physical examination, urinary albumin excretion, ECG), diabetes control and lipid profile was performed in each subject. Patients with manifest cardiovascular disease (history of myocardial infarction, angina pectoris, positive ECG (Minnesota codes 1-1, 1-2, 8-1, 8-3), cerebrovascular accident and/or peripheral vascular disease) were excluded. Retinopathy was diagnosed by the ophthalmologist by means of fundoscopic examination. Microalbuminuria was defined as albumin excretion rate $\geq 3 \mathrm{mg} / \mathrm{mmol}$ creatinine in an early morning urine specimen on at least two consecutive occasions ${ }^{16}$. No patients use drugs that could influence hemostasis.

Twenty-seven type 1 diabetic patients with vascular complications (18 with retinopathy, 9 with retinopathy and albuminuria) were included in the present study. Nineteen type 1 diabetic patients free of complications, matched for age and metabolic control, served as controls. The characteristics of the subjects studied are depicted in Table 4.1. Part of these data has already been reported earlier ${ }^{11}$.

Table 4.I Demographic parameters of type 1 diabetic patients at baseline.

\begin{tabular}{|c|c|c|c|}
\hline & \multirow{2}{*}{$\begin{array}{c}\text { DM without } \\
\text { complications } \\
\text { I }\end{array}$} & \multicolumn{2}{|c|}{ DM with enmplications } \\
\hline & & $\begin{array}{c}\text { Retinopathy } \\
\text { II }\end{array}$ & $\begin{array}{c}\text { Retinopathy + allhuminurial } \\
\text { III }\end{array}$ \\
\hline n & 19 & 18 & 9 \\
\hline Sux ratio & $11 \mathrm{M} / \mathrm{sg}=$ & SMMF & $3 \mathrm{M} / 6 \mathrm{~F}$ \\
\hline Age $(y c a n)$ & $39+8$ & $42+9$ & $39 \pm 10$ \\
\hline Dunation diatheles lyostos & $\left(1+(2-32)^{\circ}\right.$ & $22(11.40)$ & $23(14 \cdot 36)$ \\
\hline Donsage insuli: (IU/diry) & $48+16$ & $45 \pm 12$ & $49 \pm 11$ \\
\hline Buly mass index $\left(k_{1} \sin ^{2}\right)$ & $27.8 \pm 4.5$ & $25.4 \pm 2.6$ & $22.6 \pm 1.7$ \\
\hline 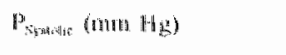 & $126 \pm 11$ & $13: \pm 12$ & $130 \pm 10$ \\
\hline 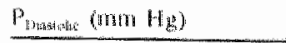 & $81+6$ & $79 \pm 8$ & $80 \pm 6$ \\
\hline
\end{tabular}

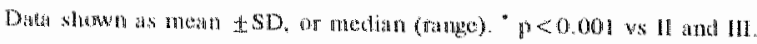

Each study started at $08.00 \mathrm{a} . \mathrm{m}$. while the subject was still fasting. In order to investigate the binding characteristics of TFPI to glycosaminoglycans at the endothelial cell surface, TFPI activity was measured before and after heparin administration. With the subject in supine position blood samples were taken via an indwelling catheter in a vein of the forearm just before and 3,5,10 and 30 minutes after an intravenous bolus injection of $5,000 \mathrm{IU}$ of unfractionated heparin (Leo, 
Denmark). For determining TFPI activity, VWF, thrombomodulin, t-PA and PAI-1, blood samples were collected in tubes containing sodium citrate $3.25 \%$ (dilution 1:10). Fasting blood samples were also drawn for determination of glycated hemoglobin $\left(\mathrm{HbA}_{\mid c}\right)$ and lipid profile at baseline. The protocol was approved by the Ethical Committee of the University Hospital, while written informed consent was obtained from all participants.

TFPI activity was measured using the chromogenic substrate assay according to Sandset after polybrene pretreatment (expressed in $\%$ with regard to standardized TFPI activity, measured in a plasma pool obtained from 45 healthy donors; $\mathrm{CV}$ $7.4 \%$ at $100 \%$ level in our laboratory $)^{17}$. The increase in TFPI activity from baseline after heparin administration was also estimated by integral calculus as the incremental area under the curve (AUC). The results of the calculations of AUC are shown dimensionless. Plasma levels of $\mathrm{VWF}$ were determined by an ELISA method using rabbit anti-human $\mathrm{VWF}$ (Dako A/S, Denmark; $\mathrm{CV} 7 \%$; normal range 60-180\%). Thrombomodulin (Diagnostica Stago, France; CV 8\%; mean 24 ng $\mathrm{ml}^{-1}$ ) and t-PA antigen (Innogenetics, Belgium; $\mathrm{CV} 7 \%$; normal range 1.3-10.4 ng $\mathrm{ml}^{-1}$, mean $4.1 \pm 2.4 \mathrm{ng} \mathrm{ml}^{-1}$ ) were measured by enzyme immunoassay. PAl-1 activity was photometrically measured (Kabi Diagnostica, Sweden; intra-assay $\mathrm{CV} 6 \%$; normal range 1-20 $\mathrm{AU} \mathrm{ml}^{-1}$, median $8 \mathrm{AU} \mathrm{ml}^{-1}$ ). $\mathrm{HbA}_{\mathrm{lc}}$ was measured by column chromatography (Diamat, Bio-Rad, USA). Serum total and HDLcholesterol and triglycerides were determined with enzymatic methods. (Unimate 5 and 7, Roche, Basle, Switzerland), and apo $A_{1}$ and apo B were measured with immunoturbidimetry (Uni-kit, Roche). LDL-cholesterol was calculated with the Friedewald formula. Lipoprotein (a) was determined by a solid-phase, two-site immunoradiometric assay using two monoclonal antibodies directed toward different epitopes of apo(a) (Pharmacia Diagnostics, Uppsala, Sweden). At a Lp(a) concentration of $200 \mathrm{U}^{-1}$ the within-assay coefficient of vartation is $4 \%$. An enzymatic hexokinase method (Unimate 5, Roche) was used for measuring serum glucose concentrations. Serum free insulin was measured with a double antibody radioimmunoassay after polyethylene glycol pretreatment (Pharmacia Diagnostics; within-assay $\mathrm{CV} 3.4-6.1 \%$ in the range of $3.50 \mathrm{mU}^{14}$ ). For determination of urinary albumin an immunoturbidimetric technique was applied (Uni-kit, Roche; interassay CV $3 \%$ ).

\section{Statistics}

All data are expressed as mean \pm SD or as median and range when not normally distributed. Because of repeated measurements in time a multiple analysis of variance (MANOVA) for repeated measurements was performed. For comparing more than two groups, one-way analysis of variance (ANOVA) with Student- 
Newman-Keuls correction for multiple comparisons was used. The Kruskal- Wall is analysis of variance was applied if data were not normally distributed. Categorical variables were analyzed by the chi-square test. P-values $\leq 0.05$ were considered statistically significant. The partial correlation coefficient was determined by stepwise multiple regression analysis.

\section{Results}

The mean duration of disease in the diabetic subjects without complications was shorter than in the patients with only retinopathy or with retinopathy and albuminuria (Table 4.1). However, the three groups did not differ with regard to gender, age, body mass index, blood pressure or daily insulin dosage. Three subjects with retinopathy and three with albuminuria received antihypertensive medication. There were no differences in smoking habits or use of alcohol. Regarding the metabolic parameters, the three groups were well-matched for $\mathrm{HbA}_{\text {ic }}$ (Table 4.2). Serum lipids, apo $A_{1}$ and $B$, lipoprotein (a) and insulin levels were similar in the three groups.

Table 4.2 Lathoratory parameters of type 1 diabetic patients at baseline.

\begin{tabular}{|c|c|c|c|}
\hline & \multirow{2}{*}{$\begin{array}{l}\text { DM without } \\
\text { complications } \\
1\end{array}$} & \multicolumn{2}{|c|}{ DN with complications } \\
\hline & & $\begin{array}{c}\text { Retinopathy } \\
\text { II } \\
\end{array}$ & $\begin{array}{c}\text { Retinopathy }+ \text { allouminuria } \\
\text { III }\end{array}$ \\
\hline Gilyested hatemaghobis $(\%)$ & $8.8+1.0$ & $8.7 \pm 1.1$ & $9.4=1.7$ \\
\hline 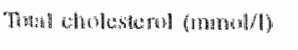 & $50 \pm 0.7$ & $5.6 \pm 0.8$ & $5.5 \pm 1.0$ \\
\hline 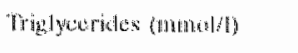 & $1.10(0.6-5.22)$ & $1.01(0.5-2.26)$ & $1.33(0.84-2.42)$ \\
\hline Hol thaylestern (manofid) & $1.35 \pm 0.43$ & $1.51 \pm 0.43$ & $1.34 \pm 0.2$ \\
\hline 1. Dl. chotasemel (monolfy & $3.61+0.79$ & $3.59 \pm 0.72$ & $3.51+1.1$ \\
\hline$A p h A_{1}(\mathrm{gefl})$ & $1.60+0.28$ & $1.65+0.26$ & $1.65 \pm 0.22$ \\
\hline$A D O B Q Q 1)$ & $1.01 \pm 0.21$ & $1.10-10.19$ & $1.19=0.25$ \\
\hline 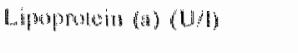 & $105(4857)$ & $147(25-622)$ & $109(34-907)$ \\
\hline 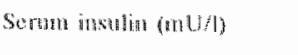 & $7.0(3.6442 .4)$ & $8.1(4.5-12.4)$ & $8.2(6.9-43.9)$ \\
\hline 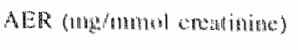 & $0.5(0.2 .7)$ & $0.4(0)(6)$ & $20(5.6-38.0)$ \\
\hline
\end{tabular}

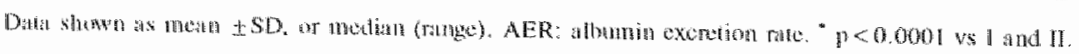


The endothelium-dependent hemostatic parameters VWF and t-PA were not different in the three groups (Table 4.3).

Table 4.3 Hemostatic parameters of type 1 diabetic subjects at baseline.

\begin{tabular}{|c|c|c|c|}
\hline & \multirow[t]{2}{*}{ DM without complications } & \multicolumn{2}{|c|}{ DM with comentheations. } \\
\hline & & Rettinopathy & Retinopathy + allowmirsuria \\
\hline & 1 & $\llbracket$ & 111 \\
\hline Von Willebrand lactor (尔) & $132 \pm 42$ & $118 \pm 41$ & $130+40$ \\
\hline Thrombomodutin (ryg/m) & $2 x+9$ & $26 \pm 7$ & $44 \pm 24^{\circ}$ \\
\hline S-PA (ng/ml) & $2.81 \pm 1.26$ & $3.01 \pm 1.44$ & $2.77 \pm 1.34$ \\
\hline PAll (AU/mi) & $3(0-15)$ & $2(0-6)$ & $1(0-8)^{3}$ \\
\hline
\end{tabular}

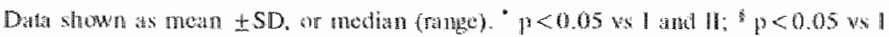

Thrombomodulin levels were significantly higher $(p<0.05)$ in the albuminuric patients, compared to the patients with only retinopathy or without complications. PAI-1 activity was lower in the patients with albuminuria in comparison with the uncomplicated patients $(\mathrm{p}<0.05)$. However, the PAI-1 levels were within the normal range in all three groups. Basal TFPI activity was significantly higher in the patients with albuminuria, compared to the patients with only retinopathy or those without complications $(121 \pm 10 \%$ vs $111 \pm 8 \%$ and $110 \pm 13 \%$ respectively, $p<0.05$; Figure 4.1). A positive correlation between basal TFPI and albuminuria was found $(r=0.66, p<0.05$; Figure 4.2$)$, while no correlation between basal TFPI and $\mathrm{HbA}_{1 \mathrm{c}}$ existed. TFPI activity in the albuminuric group was significantly higher at all time points after the bolus injection of heparin, in comparison with the uncomplicated subjects $(p<0.01)$. Compared to the patients with retinopathy, the albuminuric patients had higher TFPI activity from 5 to 30 minutes postheparin $(p<0.05 ;$ Figure 4.1$)$. The increase in postheparin TFPI activity, as measured as the incremental area under the curve (AUC), was higher in the abuminuric group than in the uncomplicated group $(65 \pm 7$ vs $59 \pm 4, p<0.05)$. This increase in postheparin TFPI activity was independent of the TFPI activity at baseline. In contrast to basal TFPI activity, a weak correlation $(r=0.39, p<0.01)$ between postheparin TFPI activity and $\mathrm{HbA}_{\mathrm{f}}$ could be demonstrated. No correlation between the other endothelium-dependent parameters and basal TFPI activity was found, while postheparin TFPI activity was negatively correlated with WWF $(r=-0.38, p<0.01)$. Stepwise multiple regression analysis revealed albuminuria to be the only independent parameter associated with basal TFPl activity in the complicated patients (partial correlation coefficient; $0.56, p<0.001$ ). 


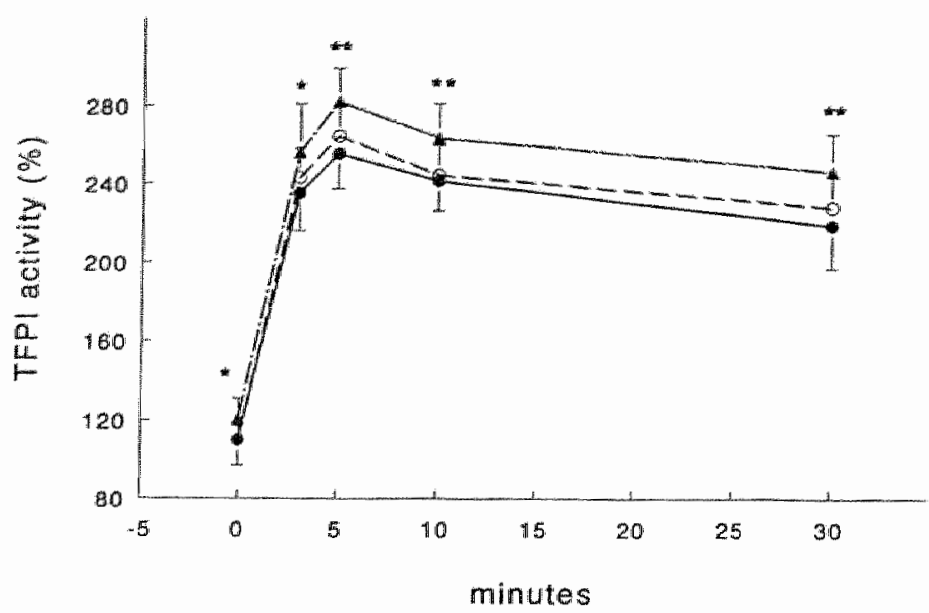

figure 4.1 TFPl acrivity, before and after an i.v. boles injection of 5,000 IU of heparin in un. complicated type 1 diabetic patients $(\bullet ; n=19$ ), patients with only retinopathy ( 0 ; $\mathrm{n}=18$ ) or with retinopathy and abumimuria ( 4 ; $=9$ ). Basal TFPI activiry is significantly higher in the albuminuric group, compared to the uncomplicated and retinopathic group (* $p<0.05$ ). TFPl activity is also significantly higher in the patients with albuminuria al all cime points after heparin administration (* $p<0.05$; $p<0.01$ vs uncomplicated, and $p<0.05$ vs retinopathic group). The incredse in TFPI activity is independent of hasal TFPl activity.

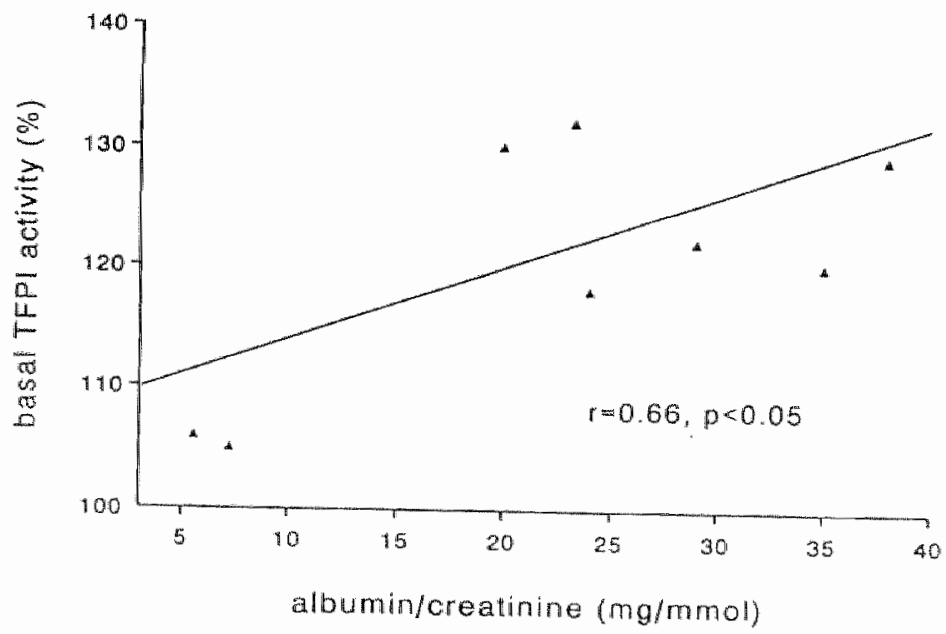

Figure 4.2 Correlation between basal TFPI activity and albuminuria. 


\section{Discussion}

In the present study, we demonstrated significantly higher basal and postheparin TFPl activity in type 1 diabetic patients with retinopathy and albuminuria, compared to patients with only retinopathy or without complications. The increase in TFPI activity after heparin administration was independent of basal TFPI activity. The major determinant of these increased levels of TFPI was albuminuria. Simultaneously, thrombomodulin levels were significantly increased in the albuminuric patients, while no differences in the levels of von Willebrand and t-PA were found.

In an earlier study, we demonstrated that an increased basal TFPI activity in type 1 diabetic patients does not result from a reaction to a prethrombotic state ${ }^{11}$. Because TFPI is produced by and mainly bound to the vascular endothelium, it may reflect endothelial function. At the endothelial cell surface, TFPI is probably bound to glycosaminoglycans, such as heparan sulfate ${ }^{5.6}$. In comparison with retinopathy, (micro)albuminuria is more consistently associated with generalized angiopathy in diabetic subjects ${ }^{18,19}$. It is suggested that alterations in endothelial intracellular enzymes, inwolved in the metabolism of glycosaminoglycans, constitute the primary cause of albuminuria and the associated complications ${ }^{18}$. Diabetes affects heparan sulfate metabolism ${ }^{20.21}$, partly by the inhibition of glucosaminyl $\mathrm{N}$-deacetylase, a key enzyme in heparan sulfate synthesis, due to hyperglycemia ${ }^{22}$. Genetic defects in the regulation of glycosaminoglycan production, resulting in a decreased synthesis, have also been suggested to exist in diabetic patients with nephropathy ${ }^{2.3}$. The loss of heparan sulfate, the main glycosaminoglycan component of basement membranes of glomeruli, will lead to loss of anionic sites, and subsequently albuminuria may develop ${ }^{24.25}$. Indeed, it has been shown in type 1 diabetic patients with nephropathy that heparan sulfate is decreased within the glomerular basement membrance ${ }^{26}$. In animals with streptozotocin-induced diabetes, a reduction in the synthesis of heparan sulfate by endothelial cells has also been demonstrated ${ }^{27}$. A decrease in the number of endothelial glycosaminoglycan binding sites for TFPI could result in higher levels of circulating TFPI, explaining the increased basal TFPI activity in the plasma of our albuminuric diabetic subjects. Increased unstimulated TFPI activity has also been found in patients with diabetic nephropathy by others ${ }^{9,10}$.

Not only synthesis, but also function and/or structure of endothelial glycosaminoglycans could be altered in diabetes. Gllycosaminoglycans are negatively charged due to the sulfate groups present. Inthibition of glucosaminyl $\mathrm{N}$-deacetylase also results in the synthesis of low-sulfated heparan sulfate molecules ${ }^{28}$, and a reduced negative surface charge on the arterial endothelium in diabetic rats has been demonstrated ${ }^{27}$. This may explain the increased transcapillary leakage of albumin in type 1 diabetic patients with microalbuminuria ${ }^{29}$. TFPI is bound to glycosaminoglycans with a highly positively charged COOH-terminus, a 
binding of electrostatic nature ${ }^{6}$. The increased postheparin TFPI activity in our albuminuric patients may therefore be explained by a weaker binding. As we have suggested earlier, alterations in synthesis and function of glycosaminoglycans could be the result of processes like nonenzymatic glycation, formation of advanced glycated endproducts and oxidative stress?

It is reported that concentrations of thrombomodulin, a membrane protein of the vascular endothelial cell, is increased in diabetic patients with albuminuria, suggesting generalized angiopathy to be present in this patient group ${ }^{2,30}$. We confirmed this finding in our patients. Levels of PAI-1 were lower in the albuminuric group as compared to the uncomplicated group. However, because all the PAI- 1 levels were within normal range in the three subgroups, the meaning of this finding is not clear. On the other hand, levels of t-PA and VWF were not different between our three patient groups. In the literature, some authors reported increased levels of PAI-1, WWF and t-PA, while others have observed normal or even decreased levels in diabetic patients with or without (micro)albuminuria 1.31,32. An explanation for these different observations may be a difference in metabolic control reported in the various studies. It is known that the levels of $t-P A, P A I-1$ and $v W F$ are influenced by glucose metabolism ${ }^{33-35}$. Several studies indicate poorer metabolic control in subjects with nephropathy ${ }^{1.35}$. In contrast, our patients were carefully matched for glycemic control. In addition, it is also known that these endothelium-dependent parameters are affected by the presence of hypertension ${ }^{36-38}$. Blood pressure was similar in our patients with or without complications. A third explanation may be the use of antihypertensive medication. Such therapy has a favourable effect on fibrinolytic factors and $V W F^{36,38}$. Three of our patients with retinopathy and three with albuminuria used antihypertensive drugs. When these subjects were excluded from statistical analysis, there were still no significant changes in the levels $\mathrm{t}-\mathrm{PA}$, PAI-1 or $\mathrm{VWF}$ in the three groups. One prospective study showed a rise in the levels of $\mathrm{WWF}$, in close relation to the development and progression of albuminuria ${ }^{3 y}$. However, at the start of this study, there was a difference in blood pressure and metabolic control between the group that remained normoalbuminuric and the group that developed albuminuria. In the analysis and interpretation of the data in earlier studies, blood pressure and antihypertensive therapy have not frequently been taken into account as possible confounders. Hence, the former observations regarding these endothelium-dependent factors must be interpreted cautiously.

In our earlier studly we have shown that TFPI is strongly correlated with long-term glycemic control as measured by $\mathrm{HbA}_{\mathrm{ac}}{ }^{7}$. In the present study, we therefore matched the patients for their degree of metabolic control, so that $\mathrm{HbA}_{1 \mathrm{c}}$ could not contribute as a confounding tactor. It appeared that basal TFPI activity did not correlate with $\mathrm{HbA}_{16}$, while there was only a weak correlation between postheparin TFPI activity and metabolic control. In addition, levels of serum lipids did not 
differ between the three patients groups, and in contrast to observations by others $^{40.41}$, we were unable to find correlations between TFPI activity and serum lipids and apolipoproteins.

In summary, type 1 diabetic patients with albuminuria show increased basal and postheparin TFPI activity. Because TFPI is an endothelium-dependent glycoprotein, bound to glycosaminoglycans, these findings suggest that TFPI activity could reflect disturbances in endothelial glycosaminoglycans. TFPl may therefore be considered an marker of endothelial (functional) alterations. The finding of increased thrombomodulin levels, a strong positive correlation between albuminuria and basal TFPI activity, and an increase in postheparin TFPI activity in this patient group, support this hypothesis. We postulate that alterations in metabolism and function of glycosaminoglycans, as seen in diabetes, are responsible for the increased TFPI activity in albuminuric patients. Whether TFPI activity could be an important factor with respect to diagnosing early vascular abnomalities, has still to be proven in future prospective studies. 


\section{References}

1. Jensen T, Bjerre-Knudsen J, Feldi-Rasmussen B, Deckert T. Features of endothelial dystunction in early nephropathy. Lancet 1989;1:461-3.

2. Iwashima $Y$, Sato $T$, Watanabe $K$, Ooshima $E$, Hiraishi $S$, Ishii H, Kazama M, Makino 1. Elevation of plasma thrombomodulin level in diabetic patients with early diabetic nephropathy. Diabetes 1990;39:983-8.

3. Collier A, Rumley A, Rumley AG, Paterson JR, Leach JP, Lowe GDO, Small M. Free radical activity and hemostatic factors in NIDDM patients with and without microalbuminuria. Diabetes 1992;41:909-13.

4. Lindahl AK, Sandset PM, Abildgaard U. The present status of tissue factor pathway inhibilor. Blood Coagul Fibrinol 1992;3:439-49.

5. Sandset PM, Abildgaard U, Larsen ML. Heparin induces release of extrinsic pathway inhibitor (EPD). Thromb Res 1988;50:803-13.

6. Valentin $S$, Larnkjoer A, Ostergaard P, Ilum Nielsen J, Nordfang O. Characterization of the binding between tissue factor pathway inhibitor and glycosaminoglycans. Thromb Res 1994;75:173-83.

7. Leurs PB, wan Oerle R, Mamulyák K. Wolfenbuttel BHR. Tissue factor pathway inhibitor in patients with IDDM. Diabetes 1995;44:80-4.

8. Leurs PB, van Oerle R, Wolffenbuttel BHR, Hamulyák K, D-glucose increases tissue factor pathway inhibitor (TFPI) release from cultured endothelial cells after heparin stimulation. Thromb Haemostas 1995;73:1383A.

9. Kario K, Matsuo T, Kobayashi H, Matsuo M, Sakata T, Miyata T. Activation of tissue factor-induced coagulation and endothelial cell dysfunction in non-insulindependent diabetic patients with microalbuminuria. Arterioscler Thromb Vasc Biol 1995;15:1114-20.

10. Yokoyama H, Myrup B, Rossing P, Ostergaard PB. Increased lissue factor pathway inhibitor activity in IDDM patients with nephropathy. Diabetes Care 1996;19:441-5.

11. Leurs PB, van Oerle R, Wolffenbuntel BHR, Hamulyák K. Increased tissue factor pathway inhibitor (TFPl) and coagulation in patients with insulin-dependent diabetes mellitus. Thromb Haemostas 1997;77:472-6.

12. Huvers FC, de Leeuw PW, Houben AJHM, de Haan CHA, Hamulyák K, Schouten H. Wolfenbuttel BHR, Schaper NC. Endothelial-dependent vasodilatation, plasma markers of endothelial function, and adrenergic vasoconstrictor responses in type 1 diabetes under near-normoglycemic conditions. Diabetes 1999:48:1300-7.

13. Sandset PM. Sirnes PA. Abildgaard U. Factor VIl and extrinsic pathway inhibitor in acute coronary disease. Br J Haematol 1989;72:391-6.

14. Moor E, Hamsten A, Karpe F, Bånenholm P, Blombäck M, Silveira A. Relationship of tissue pathway inhibitor activity to plasma lipoproteins and myocardial intarction at a young age. Thromb Haemostas 1994;71:707-12.

15. Kario K. Matsuo T, Yamada $T$, Matsuo M. Increased tissue factor pathway inhibitor levels in uremic patients on regular hemodialysis. Thromb Haemostas 1994;71:275-9. 
16. Ellis D, Coonrod BA, Dorman JS, Kelsey SF, Becker DJ, Avmer ED, Orchard TJ Choice of urime sample predictive of microalbuminuria in patients with insulindependent diabetes mellitus. Am J Kidney Dis 1989;13:321-8.

17. Sandset PM. Abildgaard U, Petrersen M. A sensitive assay of extrinsic coagulation pathway inhibitor (EPI) in plasma and plasma fractions. Thromb Res 1987; 47:389-400.

18. Deckert $T$, Feld-Rasmussen $B$, Borch-Johnsen $K$, Jensen $T$, Kofoed-Enevoldsen $A$. Albuminuria reffects widespread vascular damage. The Steno hypothesis. Diabetologia 1989;32:219-26.

19. Stehouwer CDA. Zellenrath P, Polak BCP, Baarsma GS, Nauta JJP. Donker AJM, den Ottolander GJH. Von Willebrand factor and early diabetic retinopathy: no evidence for a relationship in patients with type 1 (insulin-dependent) diabetes mellitus and nomal urinary albumin excretion. Diabetologia 1992;35:555-9.

20. Rohrbach DH, Wagner CW, Star VL, Martin GR, Brown KS, Yoon JW. Reduced synthesis of basement membrane heparan sulfate proteoglycan in streptozotocininduced diabetic mice. I Biol Chem 1983;258:11672-7.

21. Wu VY, Wison B, Cohen MP. Disturbances in glomerular basement membrane glycosaminoglycans in experimental diabetes. Diabetes $1987 ; 36: 679-83$.

22. Kofoed-Enewoldsen A, Noonan D, Deckert T, Diabetes mellitus induced inhibition of glucosaminyl $\mathrm{N}$-deacetylase: effect of short-term blood g/ucose control in diabetic rats. Diabetologia $\Perp 993 ; 36: 310-5$.

23. Deckert T, Horowitz IM, Kofoed-Enevolden A, Kjellen L, Deckert M, Lykkelund $\mathrm{C}$, Burcharth $\mathrm{F}$. Possible genetic defects in regulation of glycosaminoglycans in patients with diabetic nephropathy. Diabetes 1991;40:764-70.

24. Groggel GC, Stevenson $\mathrm{J}$, Hovingh $\mathrm{P}$, Linker $\mathrm{A}$, Border WA. Changes in heparan sulfate correlate with increased glomerular permeability. Kidney Int 1988;33: $517-23$

25. Cotran RS, Rennke HG. Anionic sites and the mechanisms of proteinuria. N Engl J Med 1983;309:1050-2.

26. Shimomura H, Spiro RG. Sudies on macromolecular components of human glomerular basement membrane and alterations in diabetes. Diabetes 1987:36: $374-81$.

27. Raz 1, Havivi $Y$. Yarom R. Reduced negative surface charge on arierial endothelium of diabetic rats. Diabetologia 1988:31:618-20.

28. Kjellén L, Bielefeld D, Höök M. Reduced sulfation of liver heparan sulfate in experimentally diabetic rats. Diabetes $1983 ; 32: 337-42$.

29. Feld-Rasmussen B. Increased transcapillary escape rate of albumin in type 1 (insulin-dependenc) diabetic patients with microalbuminuria. Diabetologia 1986,29: $282-6$.

30. Shimano H, Takahashi K, Kawakami M, Gotoda T, Harada K, Shimada M, Yazaki $Y$, Yamada N. Elevated serum and urinary thrombomodulin levels in patients with non-insulin-dependent diabetes mellitus. Clin Chim Acta 1994;225:89.96. 
31. Lamberton RP, Goodman AD, Kassoff A, Rubin CL. Treble DH, Saba TM, Merimee TJ, Dodds WJ. Von Willebrand factor (VIIIR:Ag), fibronectin, and insulin-like growth factors 1 and II in diabenic retinopathy and nephropathy. Diabetes 1984:33:125-9.

32. Auwerx J, Bouilion R, Collen D. Geboers J. Tissue-type plasminogen activator antigen and plasminogen activator inhibitor in diabetes mellitus. Arteriosclerosis $1988 ; 8: 68-72$.

33. Gonzalez J. Colwell A. Sarji KE, Nair RMG, Sagel J. Effect of metabolic control with insulin on plasma won Willebrand factor activity (VIII R:vWF) in diabetes mellitus. Thromb Res 1980;17:261-6.

34. Juhan-Vague I, Vague P, Poisson C, Aillaud MF, Mendez C, Collen D. Effecr of 24 hours of normoglycaemia on tissue-type plasminogen activator plasma levels in insulin-dependent diabetes. Thromb Haemostas 1984:51:97-8.

35. Bahru $Y$, Kesteven P. Alberti KG, Walker M. Decreased plasminogen activator inhibitor-1 activity in newly diagnosed type 2 diabetic patients following dietary modification. Diabet Med 1993:10:802-6.

36. Gleerup G, Winther $K$. Decreased fibrinolytic activity and increased platelet function in hypertension. Possible influence of calcium antagonism. Am J Hypertens 1991;4:168S-71S.

37. Landin $\mathrm{K}$, Tengborn L. Smith U. Elevated fibrinogen and plasminogen activator inhibitor (PAI-1) in hypertension are related to melabolic risk factors for cardiovascular disease. J Intern Med 1990;227:273-8.

38. Blann AD, Naqvi $T$, Waite $\mathrm{M}$, McCollum $\mathrm{CN}$. Von Willebrand factor and endothelial damage in essential hypertension. J Hum Hypertens 1993; 7:107-11.

39. Stehouwer CDA, Stroes ESG, Hackeng WHL, Mulder PGH, den Ottolander GHH. Von Willebrand factor and the development of diabetic nephropathy in insulindependent diabetes mellitus. Diabetes 1991;40:971-6.

40. Novotny WF, Girard TJ, Miletich JP, Broze GJ. Purification and characterization of the lipoprotein-associated coagulation inhibitor from human plasma. I Biol Chem 1989:264:18:832-7.

41. Lesnik P. Vonica A. Guerin M, Moreau M. Chapman MJ. Anticoagulant activity of lissue factor pathway inhibitor in human plasma is preferentially associated with dense subspecies of LDL and HDL and with Lp(a). Atherosel Thromb 1993; 13:1066-75. 


\section{Chapter 5}

Increased Tissue Factor Pathway Inhibitor (TFPI) and coagulation in patients with insulin-dependent diabetes mellitus

PB Leurs, R van Oerle, BHR Wolffenbuttel, K Hamulyák

Thrombosis Haemostasis 1997;77:472-6 


\section{Abstract}

Recently, we found an increase in tissue factor pathway inhibitor (TFPl) activity in patients with insulin-dependent diabetes mellitus (IDDM). This increase in TFPI activity could be the result of increased thrombin formation and/or altered binding of TFPI to glycosaminoglycans. We studied TFPI activity (chromogenic assay) in relation to prothrombin $\mathrm{F}_{1,2 .}$ fragments and endogenous thrombin potential (ETP), in 46 IDDM patients, and 18 age and sex-matched healthy controls. Prothrombin, antithrombin and thrombomodulin were also determined. In IDDM patients, TFPI activity and $F_{1+2}$ levels were significantly higher, while ETP, prothrombin antigen levels, and antithrombin activity were lower as compared to the controls. In IDDM patients with microalbuminuria, a manifestation of generalized angiopathy, TFPI activity, $F_{1+2}$ and thrombomodulin levels were higher than in patients with only retinopathy or patients without complications. No correlation between TFPI activity, $F_{1+2}$ levels and thrombomodulin was found, while TFPI activity was negatively correlated with ETP $(r-0.27)$. Microalbuminuria was significantly correlated with TFPl activity $(r=0.46), F_{1+2}$ $(r=0.56)$, and thrombomodulin $(r=0.52)$. In TFPI-depleted plasma, ETP increased, indicating that ETP is affected by TFPI. In conclusion, the increase in TFPI activity in IDDM patients may not be considered to be a reaction on a procoagulant state. It is hypohesized that vascular damage, leading to alterations in glycosaminoglycans, is in part responsible for the changes in TFPI activity, $\mathrm{F}_{1+2}$ levels and ETP. 


\section{Introduction}

It is well known that the vascular endothelium plays an essential role in the regulation of (local) hemostatic processes'. The major defence mechanisms that prevent inappropriate coagulation are found at the endothelial cell surface ${ }^{2}$. The endothelium itself is known to produce procoagulant factors like von Willebrand factor, and anticoagulant factors, such as heparan sulfate and thrombomodulin. ${ }^{3.4}$. In diabetic patients a procoagulant state is observed, which could contribute to the risk of premature cardiovascular events. This hypercoagulable state could be caused by a dysbalance between hemostatic factors in plasma, and/or at the endothelial cell surface. So far, indirect evidence for a state, favouring thrombin formation, has been gathered, mainly using plasma parameters like fibrinogen and antithrombin activity, or endothelium-dependent parameters like von Willebrand factor ${ }^{3.4}$. More recently, it is suggested that increased levels of factor VIla may produce hypercoagulability in diabetic patients with endothelial dysfunction ${ }^{5}$. Impaired fibrinolysis could also contribute to a dysbalance in hemostasis in diabetes ${ }^{4}$. Studies with human endothelial celis cultured under hyperglycemic conditions have shown prethrombotic alterations at the endothelial cell surface ${ }^{\text {th }}$ In recent years, prothrombin fragments $F_{1+2}$, which are the result of thrombin formation. are used for determining thrombin generation in vivo?. It is now also possible to assess thrombin generation in plasma ex vivo after activation of plasma by tissue factor, using the sensitive endogenous thrombin potential (ETP) according to Hemker".

A new Kunitz-type coagulation inhibitor, tissue factor pathway inhibitor (TFPI), has been recently identified ${ }^{9}$. It is produced by and mainly bound to the vascular endothelial cells, probably by glycosaminoglycans ${ }^{10-12}$. Only about $5 \%$ of the TFPI in the plasma circulates as a free, uncomplexed protein. TFPI inhibits factor $X_{a}$ and in complex with factor $\mathrm{Xa}$ also the tissue factor/factor VIla complex. TFPI activity is altered in several pathological conditions ${ }^{19-15}$. Its release from the endothelium can be stimulated by glycosaminoglycans like heparin ${ }^{16}$. Although disturbances in hemostatic parameters in diabetic patients are involved in the development of cardiovascular complications ${ }^{1720}$, little is known about TFPI activity in diabetic subjects. In non-insulin-dependent diabetic (NIDDM) patients with microalbuminuria increased llevels of TFPI have been found". We recently demonstrated that basal and postheparin TFPI activity was significantly higher in uncomplicated insulin-dependent diabetic (IDDM) subjects than in healthy controls ${ }^{2}$. A strong correlation with melabolic control was found. The explanation for these findings is not known, but alterations in binding characteristics of TFPl to glycosaminoglycans, due to glycosylation or oxidative stress could play a role. However, the increase in TFPI activity could also be secondary to increased (local) formation of thrombin. In the present sudy, we therefore examined bassal TFPI 
activity in IDDM patients, with and without complications, in relation to the degree of coagulation, measured by $\mathbb{F}_{1+2}$ fragments, antithrombin activity and thrombomodulin. In addition, we studied the ETP in relation to TFPI activity.

\section{Materials and methods}

IDDM patients were evaluated with respect to micro- and macrovascular complications (history, physical examination, fundoscopy by ophthalmologist, urinary albumin excretion, ECG) and diabetes control. Retinopathy was diagnosed by the ophthalmologist by means of fundoscopic examination. Microalbuminuria was defined as albumin excretion rate $\geq 3 \mathrm{mg} / \mathrm{mmol}$ creatinine in an early morning urine specimen on at least two consecutive occasions ${ }^{22}$. Patients with manifest cardiovascular disease (history of myocardial infarction, angina pectoris, positive ECG (Minnesota codes 1-1, 1-2, 8-1, 8-3), cerebrovascular accident and/or peripheral vascular disease) were excluded. No patients use drugs that could influence hemostasis. In addition, 18 age- and sex-matched healthy subjects recruited from a group of blood donors, served as controls.

Twenty-seven IDDM patients with vascular complications (18 with retinopathy, 9 with retinopathy and micro-/macroalbuminuria) were studied. Nineteen IDDM patients without microangiopathy were matched for age and metabolic control. The same patient population was used as described in the study of chapter 4 . The characteristics of the subjects studied are depicted in Table 5.1.

Table 5.1 Demographic and hemostatic characteristics of healthy controls and IDDM patients.

\begin{tabular}{|c|c|c|}
\hline & Controls & IDOM \\
\hline 1) & 18 & 46 \\
\hline Sex ration (moldes/lesmates) & UM/PF & $23 \mathrm{M} / 23 \mathrm{~F}$ \\
\hline Ageve ungants & $36+5$ & $40 \pm 9$ \\
\hline TFPl $(\%)$ & $945+18$ & $112 \pm 11^{\circ}$ \\
\hline$P_{1}+F_{2}($ tithollo $)$ & 0.60 .0 .17 & $0.94 \pm 0.43^{\circ \mathrm{m}}$ \\
\hline ENP (AM M gitan) & $365 \pm 52^{8}$ & $334 \pm 57$ \\
\hline 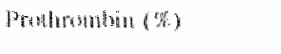 & $110+12^{\circ}$ & $97 \pm 13$ \\
\hline Aneithrombin (s.) & $4+ \pm 7^{\circ}$ & $91 \pm 11$ \\
\hline
\end{tabular}

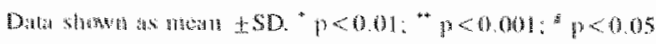

For determining TFPI activity, prothrombin fragments $F_{1+2}$, and the ETP blood samples were collected in tubes containing sodium citrate $3.25 \%$ (dilution $1: 10$ ). 
Blood samples were also drawn for determination of glycated hemoglobin in the diabetic subjects. Glycated hemoglobin ( $\mathrm{HbA}_{t c}$ fraction) was measured by column chromatography (Diamat, Bio-Rad, USA), the remainder of the blood samples were centrifuged and plasma was stored at $-70^{\circ} \mathrm{C}$ until further processing. The protocol was approved by the Ethical Committee of the University Hospital, while written informed consent was obtained from the participants.

TFPI activity was measured using the chromogenic substrate assay according to Sandset (expressed in \% with regard to standardized TFPL activity, measured in a plasma pool obtained from 65 healthy donors; CV $7.4 \%$ at $100 \%$ level $)^{23}$. In vivo thrombin generation was assessed by determination of prothrombin fragments $F_{1+2}$ using ELISA (Enzygnost Behring, Marburg, Germany; intra-assay CV 5-7.5\%, interassay $\mathrm{CV}$ 6-13\%). Ex vivo thrombin formation, following activation of the tissue factor pathway of coagulation, was measured using the computer assisted technicue according to Hemker (endogenous thrombin potential (ETP); CV 2.6\%). In short, defibrinated plasma was obtained by mixing an aliquot of plasma with $1: 50$ volume of a reptilase solution, letting a clot form for 10 minutes at $37^{\circ} \mathrm{C}$ and keeping the clotted plasma for 10 minutes at $0^{\circ} \mathrm{C}$. The fibrin formed was discarded by winding it on a small plastic spatula. The concentrations of the coagulation factors did not change significantly by the reptilase treatment ${ }^{24}$. The ETP was measured semi-automatically (Cobas Fara, Hoffmann-La Roche). To $80 \mu$ of defibinated plasma $20 \mu \mathrm{l}$ of recombinant tissue factor (Dade, USA) diluted $1: 1$ in Hepes buffer was added. After an incubation period of at least 30 seconds at $37^{\circ} \mathrm{C}$, thrombin generation was started by the addition of $20 \mu \mathrm{l}$ of a solution of chromogenic substrate SQ $68(3 \mathrm{mM})$ and calcium $(0.1 \mathrm{M})$. The substrate conversion was monitored by a continuous measurement of the optical density at $405 \mathrm{~nm}$ during 15 minutes. From the optical density-time curves the ETP was calculated in $\mathrm{nM}$. min by computer. The area under the thrombin generation curve represents the amount of substrate that thrombin, generated in the plasma, can potentially convert. Prothrombin antigen levels were measured nephelometrically, using polyclonal rabbit antihuman coagulation factor II (CLB, Amsterdam, The Netherlands; $\mathrm{CV} 5 \%$ ). Antithrombin activity was determined by a chromogenic assay (Coamatic antithrombin, Chromogenix, Sweden; CV $4 \%$ ).

In order to assess the influence of TFPI on the thrombin generation ex vivo, we depleted normal plasma of a healthy volunteer from TFPI using polyclonal antiTFPI IgG coupled to Sepharose $(1.5 \mathrm{mg} \mathrm{IgG} / \mathrm{ml}$; kindly provided by Nordfang, Novo Nordisk, Danmark). The antibody has been affinity purified on TFPI $1-161$, whereas the titer is approximately 3000 "Bethesda like" U/mg. Before and after depletion, the thrombin generation in 4 subsamples was measured. In another experiment, we added polyclonal goat-antihuman TFPI IgG antibodies $(3000 \mathrm{U} / \mathrm{ml}$; courtly received from Nordfang) to a sample of the normal plasma pool, and measured the thrombin generation in 4 subsamples before and after adding TFPl 
antibodies. TFPI activity after both TFPI depletion and treatment with TFPI antibodies was chromogenically measured. Urinary albumin was measured by an immunoturbidimetric technique (Uni-kit, Roche; interassay CV $3 \%$ ).

\section{Statistics}

All data are expressed as mean \pm SD or as median and range when not normally distributed. For comparing more than two groups, one-way analysis of variance (ANOVA) with Student-Newman-Keuls correction for multiple comparisons was used. The Kruskal-Wallis analysis of variance was applied if data were not normally distributed. Categorical variables were analyzed by the chi-square test. Pvalues $\leq 0.05$ were considered statistically significant. The partial correlation coefficient was determined by stepwise multiple regression analysis.

\section{Results}

There was no difference in age or gender between the healthy control and diabetic group or subgroups (Table 5. $\|$ and 5.2).

Table 5.2 Demographic and hemostatic parameters of IDDM patients with and without complications.

\begin{tabular}{|c|c|c|c|}
\hline & $\begin{array}{c}\text { No complicztions } \\
\qquad 1 \\
\end{array}$ & $\begin{array}{c}\text { Retinopathy } \\
\text { II }\end{array}$ & $\begin{array}{c}\text { Retinopathy }+ \text { allbuminuria } \\
\text { III }\end{array}$ \\
\hline 山 & 19 & 18 & 9 \\
\hline Sex ration (matcentiomaloss) & $\| \mathrm{M} / \mathrm{BH}$ & 9MAF" & $3 \mathrm{M} / 6 \mathrm{~F}$ \\
\hline Age (ycand & 39) 48 & $42 \pm 4$ & $39+10$ \\
\hline Glycates hemoghlutin (w) & $x 8 \pm 10$ & $8.7+1$ & $9.4 \pm 1.7$ \\
\hline TFP & $110 \pm 13$ & $111 \pm 7$ & $121 \pm 10^{\circ}$ \\
\hline$F_{y,},(n m i s / n)$ & $0.74 \pm 0.21$ & $0.82 \pm 0.19$ & $1.60 \pm 0.50^{\circ}$ \\
\hline ErP (nM ming & $357 \pm 72$ & $318 \pm 30$ & $348 \pm 56$ \\
\hline 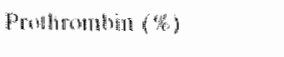 & $98+13$ & $92 \pm 12$ & $105 \pm 15$ \\
\hline Antiatrombain ( $(\%)$ & $90+10$ & $90 \pm 12$ & $94 \pm 11$ \\
\hline Thrombonoduth (ng/ml) & $28 \pm 4$ & $26 \pm 7$ & $44 \pm 24^{\circ}$ \\
\hline
\end{tabular}

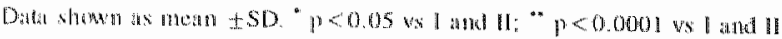


The three diabetic subgroups did not differ in HbA significantly higher in the diabetic subjects as compared to the healthy controls $(112 \pm 11 \%$ vs $99 \pm 18 \%, p<0.01)$. Compared to the patients without complications and with only retinopathy, TFPI activity was higher in the albuminuric patients (Figure 5.1).

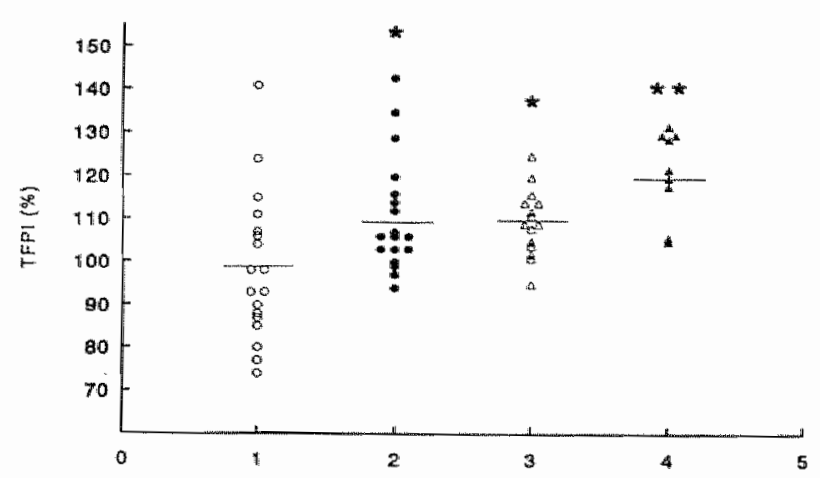

Figure 5.1 TFPI activity was significanty increased in the diabetic subgroups in comparison with the healthy controls (O). In the patients with microalbuminuria ( $A$ ). TFPl activity was significantly higher than in the pationts with only retinopathy $(\Delta)$ or without complications (๑). " $p<0.05$ ws healthy controls, " $p<0.01$ vs healthy controls, $p<0.05$ ws patients with only retinopathy or without complications.

For the prothrombin fragments $F_{1+2}$, equal results were seen. $F_{1+2}$ levels were significantly higher in the diabetic group than in the control group $(0.94 \pm 0.43 \mathrm{mmol} / 1$ vs $0.63 \pm 0.17 \mathrm{nmol} / 1, \quad \mathrm{p}<0.001)$, and were higher in the patients with albuminuria, compared to the patients with only retinopathy and uncomplicated patients (Table 5.2). The ETP was significantly higher in the controls than in the diabetic subjects $(373 \pm 50$ nM.min vs $339 \pm 57$ nM.min, $p<0.01$ ). However, in the three diabetic subgroups, the ETP was similar. Levels of prothrombin antigens were lower in the diabetic group than in the heallhy control group $(97 \pm 13 \%$ vs $116 \pm 12 \%, \mathrm{p}<0.001)$, while there were no differences between the diabetic subgroups. Antithrombin activity was also decreased in the diabetic patients in comparison with the healthy subjects $(91 \pm 11 \%$ vs $99 \pm 7 \%$, $p<0.01$ ). The antithrombin activity was not different between the diabetic subgroups. Thrombomodulin was higher in the microalbuminuric group $(44 \pm 24 \mathrm{~g} / \mathrm{ml}, p<0.05)$. TFPl activity negatively correlated with the thrombin potential $(r=-0.27, p<0.05)$ ), while no correlation with $F_{1+2}$ or thrombomodulin was found. There was also no correlation between $F_{1+2}$ and the thrombin potential. However, prothrombin was positively correlated with the ETP $(r=0.77, p<0.001)$ and antithrombin activity $(r=0.25, p<0.05)$. In the diabetic patients, micro- 
albuminuria was positively correlated with TFPI activity $(r=0.46, p<0.01), F_{1+2}$ levels $(r=0.56, p<0.001)$, and thrombomodulin $(r=0.52, p<0.001)$. When performing stepwise multiple regression analysis it appeared that only microalbuminuria (partial $r=0.56, \quad p<0.001$ ) and the thrombin potential (partial $r=-0.06, p<0.05$ ) were associated with TFPI activity, while microalbuminuria was the only determinant of the $F_{1+2}$ levels (partial $r=0.51, p<0.001$ ). When normal plasma was depleted from TFPI, an increase in ETP was seen (from $443 \pm 2$ to $490 \pm 4$ nM.min; Figure 5.2). An increase was also found when normal plasma was treated with TFPI-antibodies (from $390 \pm 4$ to $447 \pm 1$ nM.min). When measured chromogenically, TFPI activity after TFPI depletion and treatment with TFPI antibodies was less than $1 \%$.

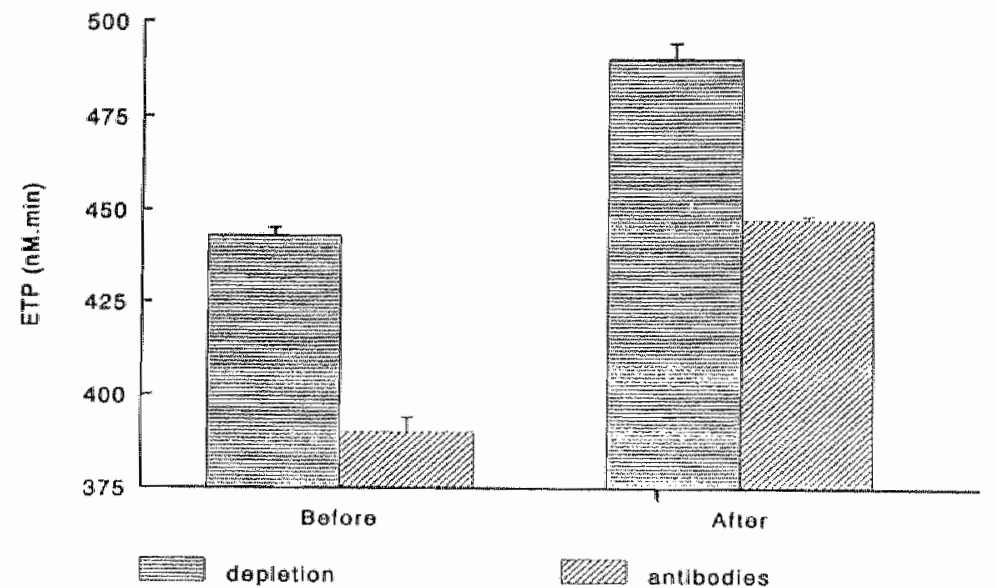

Figure 5.2 Influence of TFPl activity on the ETP in two separate experiments (see Materials and methouls). An increas in ETP is seen atter TFPI depletion or treatment with TFPI antibodies of normal plasma.

\section{Discussion}

In the preseni study, we examined the possible relationship between coagulation and TFPI activity in healthy and diabetic subjects. A procoagulant state was assessed by measuring the prothrombin fragments $F_{1+2}$ (in vivo) and the ETP (ex vivo). It appeared that TFPI activity and $F_{1+2}$ levels were increased in diabetic patients as compared to healthy controls. On the other hand, the ETP was decreased. However, no correlation between TFPI activity and $F_{1+2}$ levels was found, while a negative correlation between TFPl activity and the ETP existed. In 
the microalbuminuric patients, TFPI activity, $F_{t+2}$ levels, and thrombomodulin were higher than in the patients with only retinopathy or without complications. Microalbuminuria was strongly correlated with TFPI activity, $F_{1+2}$ levels, and thrombomodulin.

In an earlier study, we demonstrated an increased TFPI activity in diabetic patients $^{21}$. From the data of the present study, it can be concluded that this seems especially to be true for diabetic subjects with microalbuminuria. In contrast to retinopathy, microalbuminuria is more consistently associated with generalized angiopathy ${ }^{25.25}$. It is suggested that alterations in enzymes, involved in the metabolism of glycosaminoglycans constitute the primary cause of albuminuria and the associated complications ${ }^{25}$. Because TFPI is mainly bound to the vascular endothelium, probably by glycosaminoglycans, this could suggest that increased TFPI activity reflects endothelial dysfunction. Because TFPI is a coagulation inhibitor, this increase could also be a compensatory reaction on a procoagulant state, as can be found in diabetes. Presently, not only TFPI activity, but also $F_{i+2}$ levels were increased in the diabetic subjects as compared to the healthy controls. $F_{1+2}$ are formed during thrombin formation, while antithrombin, in complex with glycosaminoglycans, decreases $F_{1+2}$ formation by inhibiting the generation of thrombin ${ }^{27}$. In diabetic subjects, one of the potential defects in the natural anticoagulant mechanisms that might lead to elevated $F_{1+2}$ levels could be a decreased synthesis of glycosaminoglycans like heparan sulfate by endothelial cells ${ }^{28}$. A diminished synthesis of endothelial glycosaminoglycans is likely to reduce the activity of the endogenous heparan sulfate-antithrombin mechanism ${ }^{27}$. In addition, it has been shown that antithrombin activity is decreased by nonenzymatic glycation $^{29}$. In agreement with these data, we found a decreased antithrombin activity in our diabetic patients in comparison with the healthy controls. We believe that the increase in TFPI activity in the present study does not result from a prethrombotic state, as indicated by increased levels of $F_{1+2}$. However, the increase of TFPI activity and $F_{1+2}$ levels could be the result of vascular endothelial damage leading to alterations in glycosaminoglycans. This lyypothesis is supported by the finding that TFPI activity, $F_{1+2}$ levels and thrombomodulin are increased in the microalbuminuric patients as compared to the retinopathic and uncomplicated patients. In addition, TFPI activity, $F_{1+22}$ and thrombomodulin were positively correlated with microalbuminuria, while no relation between TFPl activity and $F_{1+2}$ or thrombomodulin was found.

Although an increase in $F_{1+2}$ levels indicates an in vivo state, favouring clot formation, we could not confirm this by the ex vivo measurement of the thrombin potential in plasma, which was decreased in the diabetic patients. A negative correlation between TFPI activity and the ETP was found. The possible influence of TFPI on the generation of thrombin was therefore further explored by assessing 
the ETP in TFPI depleted plasma and plasma treated with TFPI antibodies. A decrease in TFPI activity resulted in an increase in ETP. From these data, we conclude that the decreased ETP in diabetic patients is, at least in part, caused by an increased TFPI activity in plasma. The discrepancy between the $F_{1+2}$ levels and the ETP underlines the importance of the endothelium in the pathogenesis of clotting disturbances leading to cardiovascular events in diabetes.

The thrombin generation is also affected by prothrombin levels and antithrombin activity. Prothrombin levels were lower in the diabetic group as compared to the controls, which could result in a decreased ETP. On the other hand, antithrombin activity was also decreased in our diabetic subjects, which could lead to an increased ETP. We found a decrease in ETP, suggesting a predominant effect of lower prothrombin levels and higher TFPI activity on the ETP in our diabetic subjects.

Thrombomodulin, a membrane proteoglycan of the vascular endothelial cell, provides binding sites for thrombin ${ }^{3 n}$. In complex with thrombomodulin, thrombin loses its procoagulant properties, and this will result in an accelerated inhibition of formation and inactivation of thrombin by antithrombin ${ }^{27}$. Diabetes is characterized by the formation of advanced glycation endproducts (AGEs). It has been shown that the endothelial cell surface thrombomodulin activity is decreased by $\mathrm{AGEs}^{3}$. In addition, thrombomodulin is considered to be a marker of endothelial damage, because of increased plasma levels of thrombomodulin in diabetic patients with nephropathy ${ }^{18}$. We could confirm this in our microalbuminuric patients, in whom the plasma thrombomodulin levels were increased compared to the other diabetic groups. A decrease in thrombomodulin activity and thrombin binding sites could also lead to increased $\mathrm{F}_{1+2}$ levels. This may also explain the finding that the microalbuminuric patients with increased TFPI activity showed no decreased ETP as compared to the other diabelic suhgroups. The effect of the inoreased TFPI activity on ETP is probably neutralized by an decreased activity of endothelial cell surface thrombomodulin activity. The finding that antithrombin activity and prothrombin antigen levels did not differ between the diabetic subgroups supports this hypothesis.

In conclusion, the increase in TFPI activity in IDDM patients may not be considered a compensatory reaction on a procoagulant state as measured by an increase in $F_{1+2}$. Besides, the ETP is decreased in IDDM subjects as compared to non-diabetic controls, partly because of an increment of TFPI activity and lower prothrombin levels seen in diabetic patients. A procoagulant state could be the result of disturbances in hemostatic factors in plasma and/or at the endothelial cell surface. We postulate that an increase in TFPI activity in diabetes does not result from a prethrombotic state in plasma, but probably reflects vascular endothelial damage, resulting in alterations in glycosaminoglycans and/or binding properties of 
TFPI to glycosaminoglycans. To explain the association between diabetes and the occurrence of premature cardiovascular events, it is hypothesized that an local decrease in anticoagulant surface activity of TFPI at the site of endothelial damage is important, especially in a procoagulant surrounding. In this respect, the value of the ETP has not yet been proven, and therefore needs further investigation. 


\section{References}

1. Stern DM, Esposito C, Gerlach H, Gerlach M, Ryan J, Handley D, Nawroth P. Endothelium and regulation of coagulation. Diab Care 1991; 14(S1):160-6.

2. Bourin M, Lindahl U. Glycosaminoglycans and the regulation of blood coagulation. Biochem \& 1993;289:313-30.

3. Ostermann $\mathrm{H}$, van de Loo J. Factors of the hemostatic system in diabetic patients. A survey of controlled studies. Haemostas is 1986;16:386-416.

4. Carmassi F, Morale M, Puccetti R, De Negri F, Monzani F, Navalesi R, Mariani G. Coagulation and fibrinolytic system impaiment in insulin dependent diabetes mellitus. Thromb Res 1992:67:643-54.

5. Kario K, Matsuo T, Kobayashi H, Matsuo M. Sakata T, Miyata T. Acilivation of tissue factor-induced coagulation and endothelial cell dysfunction in non-insulindependent diabetic patients with microalbuminuria. Arterioscler Thromb Vasc Biol $1995 ; 15: 1114-20$.

6. Maiello M. Boeri D, Podesta F, Cagliero E, Vichi M, Odetti P, Adezati L, Lorenzi M. Increased expression of tissue plasminogen activator and its inhibitor and reduced fibrinolytic potential of human endothelial cells cultured in elevated glucose. Diabetes 1992:41:1009-1.5.

7. Pelzer H, Schwarz A, Stuber W. Determination of human prothrombin activation tragment $1+2$ in plasma with an antibody against a syntheric peptide. Thromb Hemostas 1991;65:153-9.

8. Hemker HC, Wielders S, Kessels H, Béguin S. Continuous registration of thrombin generation in plasma, its use for determination of the thrombin potential. Thromb Haemostas 1993;70:617-24.

9. Broze GJ, Miletich JP: Characterization of the inhibition of tissue factor in serum. Blood 1987;69:150-5.

10. Bajaj MS, Kuppuswamy MN, Saito H, Spitzer SG, Bajaj SP. Cultured normal human hepatocytes do not synthesize liporpotein-associated coagulation inhibitor: evidence that endothelium is the principal site of its synthesis. Proc Natl Acad Sci USA 1990:87:8869-73.

11. Lindall AK, Sandset PM, Abildgaard U. The present status of tissue factor pathway inhibitor. Blood Coagul Fibrinol 1992;3:439-49.

12. Vatentin $S$, Larnkjoer $A$. Ostergaard $P$, llum Nielsen $J$, Nordfang $O$. Characterization of the binding between lissue factor pathway inhbitor and glycosaminoglycans. Thromb Res 1994:75:173-83.

13. Sandset PM, Sirnes PA, Abildgard U. Factor VII and extrinsic pathway inhibitor in acute coronary disease. Br I Haematol $\llbracket 989 ; 72: 391-6$.

14. Moor E, Hamsten A. Karpe F, Bảvenholm $P$, Blombăck $M$, Silveira $A$ : Relationship of tissue pathway inhibitor activity to plasma lipoproteins and myocardial infarction at a young age. Thromb Haemostas 1994;71:707-12.

15. Kario K, Matsuo $T$, Yamada $T$, Matsuo M. Increased tissue factor pathway inhibitor levels in uremic patients on regular hemodialysis. Thromb Haemostas $1994: 71: 275-9$ 
16. Sandset PM, Abildgaard U, Larsen ML. Heparin induces release of extrinsic pathway inhibitor (EPI). Thromb Res 1988:50:803 13.

17. Jensen $T$. Increased plasma concentration of von Willebrand factor in insulin dependent diabetics with incipient nephropathy. Br Med J 1989; 298: 27-28.

18. Iwashima $Y$, Sato T, Watanabe K, Ooshima E, Hiraishi S, Ishii H, Kazama M. Makino I. Elevation of plasma thrombonodulin level in diabetic patients with early diabetic nephropathy. Diabetes 1990;39:983-8.

19. Collier A, Rumley A, Rumley AG. Paterson JR, Leach JP, Lowe GDO, Small M. Free radical activity and hemostatic factors in NIDDM patients with and without microalbuminuria. Diabetes 1992:41:909-13.

20. Myrup $B$, Rossing $P$, Jensen $T$, Gram I, Kluft $C$, Jespersen J. Procoagulant activity and intimal dysfunction in IDDM. Diabetologia 1995;38:73-8.

21. Leurs PB, van Oerle R, Hamulyák K. Wolffenbuttel BHR. Tissue factor pathway inhibitor in patients with IDDM. Diabetes 1995:44:80-4.

22. Ellis D, Coonrod BA, Dorman JS, Kelsey SF, Becker DJ, Avner ED, Orchard TJ. Choice of urine sample predictive of microalbuminuria in patients with insulindependent diabetes meilitus. Am J Kidney Dis 1989;13:321-8.

23. Sandset PM, Abildgaand U, Pettersen M. A sensitive assay of extrinsic coagulation pathway inlribitor (EPI) in plasma and plasma fractions. Thromb Res 1987:47: $389-00$.

24. Hemker HC, Willems GM, Béguin S. A computer assisted method to obtain the prothrombin activity velocity in whole plasma independent of thombin decay processes. Thromb Haemostas 1986;56:9-17.

25. Deckert T, Feldt-Rasmussen B, Borch-Johnsen K, Jensen T, Kofoed-Enevoldsen A. Albuminuria reflects widespread vascular damage. The Steno hypothesis. Diabetologia 1989;32:219-26.

26. Stehouwer CDA, Zellenrath P, Polak BCP, Baarsma GS, Nauta IJP, Donker A.IM, den Ottolander GilH. Von Willebrand factor and early diabetic retinopathy: no evidence for a relationship in patients with type $\|$ (insulin-dependent) diabetes mellitus and normal urinary abumin excretion. Diabetologia 1992:35:555-9.

27. Bauer KA. Rosenberg RD. The pathophysiology of the prethrombotic slate in humans: insights gained from studies using markers of hemostatic system activation. Blood 1987:70:343-50.

28. Kanwar YS, Rosenzweig L., Linker A, Jakubowski ML. Decreased de nowo synthesis of glomerular proteoglycans in diabetes: biochemical and auloradiographic ewidence. Proc Natl Acad Sci USA 1983;80:2272-5.

29. Villanueva GB, Allen $N$. Demonstration of altered antidhombin III activity due to nonenzymatic glycosylation at glucose concentration expected to be encountered in severely diabetic patients. Diabetes 1988:37:1103-7.

30. Esmon CT, Owen WG. Identification of an endothelial cofactor for thrombincatalyzed activation of protein C. Proc Natt Acad Sci USA 1981;78:2249-52. 
31. Esposito C, Gerlach H, Bren J, Stern D, Vlassara H. Endothelial receptor-mediated binding of glucose-modified albumin is associated with increased monolayer permeability and modulation of cell suriace coagulant properties. I Exp Med $1989 ; 170: 1387-407$. 


\section{Chapter 6}

Tissue factor pathway inhibitor and other endotheliumdependent hemostatic factors in the elderly with normal or impaired glucose tolerance and type 2 diabetes mellitus

PB Leurs, RP Stolk, K Hamulyák, R van Oerle, DE Grobbee, BHR Wolffenbuttel 


\begin{abstract}
Impaired glucose tolerance (IGT) is believed to be a prediabetic phase, which precedes the development of type 2 diabetes mellitus. In elderly subjects, IGT and diabetes are both independently associated with the occurrence of cardiowascular disease. Because endothelial damage precedes atherosclerotic changes of the vascular wall, several markers of endothelial dysfunction, eg won Willebrand factor (vWF), tissue plasminogen activator (i-PA), plasminogen activator inhibitor cype- $(\mathrm{PA}-1)$ and thrombomodulin, were studied in a population-based study concerning elderly subjects with normal (NGT) or impaired glucose tolerance and type 2 diabetes mellitus. Besides these endothelium-dependent factors, we also investigated tissue factor pathway inhibitor (TFPI) activity in relation to metabolic parameters and cardiovascular risk factors. In earlier reports, TFPI activity has been shown to be increased in diabetic subjects, especially with albuminuria. All data were adjusted for age. Increased levels of WWF antigen, t-PA antigen and PAI-I activity were seen in the IGT and diabetic group as compared to the NGT group. TFPI activity and thrombomodulin levels were increased in all elderly subjects with no differences between the groups. There was a positive association between $\mathrm{HbA}_{\mathrm{ic}}$ and TFPI activity and $\mathrm{VWF}$ antigen. Fasting blood glucose correlated with $\mathrm{WWF}$ antigen, $\mathbb{E}-\mathrm{PA}$ antigen and PAI-I activity, while urine albumin excretion correlated with TFPI activity, VWF antigen and PAI- 1 activity. Serum insulin levels correlated strongly not only with vWF antigen and I-PA antigen, but with PAI-1 activity as well. This correlation did not change after further adjustment for serum glucose and $\mathrm{HbA}_{10}$, which may suggest that in the elderly subjects impaired fibrinolysis is probably associated with insulin resistance. There were no associations between the endothelium-dependent hemostatic factors and lipids, except for a negative correlation between HDL-cholesterol and thrombomodulin. It is concluded that in elderlly subjects with IGT several endothelium-dependent hemostatic factors are already consistently increased, indicating endothelial damage in this stage.
\end{abstract}




\section{Introduction}

The state of impaired glucose tolerance (IGT) is considered to be a transitional phase to the development of type 2 diabetes mellitus. The prevalence of IGT and type 2 diabetes is increasing with age ${ }^{1-3}$. Not only ageing itself is a risk factor for atherosclerosis, but IGT and diabetes as well are both independently associated with the occurrence of cardiovascular disease $e^{4.5}$. There are several factors that contribute to the development of cardiovascular disease in diabetic and nondiabetic subjects, such as dyslipidemia, (micro)albuminuria and hypertension ${ }^{6-1}$. Hyperinsulinemia as an independent risk factor is controversia ${ }^{13}$. It has been shown that endothelial damage precedes atherosclerotic changes of the vascular wall. Therefore, several markers of endothelial (dys)function like von Willebrand factor (vWF), tissue plasminogen activator (t-PA), plasminogen activator inhibitor type-1 (PAI-1) and thrombomodulin, have been studied in the past, in order to assess whether they can predict the risk for developing cardiovascular disease ${ }^{14,15}$. Recently, we and others have demonstrated increased tissue factor patioway inhibitor (TFPI) activity in diabetic patients ${ }^{16.17}$. Particularly, this seems to be true in diabetic patients with (micro)albuminuria ${ }^{17,18}$. Because TFPl is mainly produced by and bound to the vascular endothelium, possibly by glycosaminoglycans ${ }^{19}$, these data suggest that TFPI may also reflect endothelial (dys)function. Besides, TFPl is also partly associated with lipoproteins ${ }^{20.21}$. In a population-based study, we siudied TFPI activity and other endothelium-dependent factors in elderly subjects with normal glucose tolerance (NGT), IGT, and diabetes type 2.

\section{Subjects, material and methods}

The study was conducted in participants of the Rotterdam Study, a populationbased prospective cohort study of determinants of chronic disabling diseases in the elderly ${ }^{22}$. The baseline examinations were conducted between 1990 to 1993, and included 7983 subjects (response rate $78 \%$ ). Informed consent was obtained from all subjects, and the study was approved by the medical ethics committee of the Erasmus University Medical School. The participants were evaluated with respect to micro- and macrovascular complications (history, physical examination, urinary albumin excretion, ECG), diabetes control and lipid profile. Grade of retinopathy was assessed by an ophthalmologist by means of fundoscopic examination. During the first follow-up examination of the Rotterdam Study in 1993-1994, a sample of participants was invited from those age 55 to 75 years at baseline for an addlitional diabetes examination, including an oral glucose tolerance test. The overall response rate for the follow-up examination was $90 \%$; 1107 subjects participated in the diabetes study. The present study population consists of a random sample of 144 
men and women, who were divided according to their glucose tolerance at followup, using the WHO criteria, into a group with normal glucose tolerance, impaired glucose tolerance and diabetes. The subjects did not use medication, that could influence hemostasis. The characteristics of the subjects studied are depicted in Table 6.1.

Table 6.1 Characteristics of subjects with normal and impaired glucose tolerance, and type 2 diabetes.

\begin{tabular}{|c|c|c|c|}
\hline & Normal & IGT & Type 2 disubetes \\
\hline Gander (milutentales & $18 M: 33 F$ & $23 \mathrm{M}: 25 \mathrm{~F}$ & $29 \mathrm{M}: 1 \mathrm{gF}$ \\
\hline Age (yours) & $65+16$ & $69 \pm 6^{\circ}$ & $69+16^{\circ}$ \\
\hline 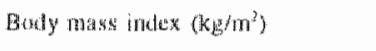 & $25.5 \pm 3$ & $28.0 \pm 3.5^{*}$ & $27.3 \pm 3.3^{*}$ \\
\hline Symalie blond pressure (nom $\mathrm{Hg}$ ) & $133 \pm 23$ & $150 \pm 20^{\circ}$ & $146 \pm 21^{\circ}$ \\
\hline Distolotio blond presisure (mon $\mathrm{Hg}$ ) & $75+11$ & $82 \pm 9^{\overline{4}}$ & $79+12$ \\
\hline$H H_{B} A_{i}(W)$ & $57+105$ & 60.40 .5 & $72 \pm 1.3^{* *}$ \\
\hline 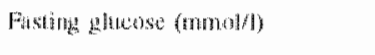 & $5.4 \pm 0.3$ & 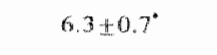 & $7.0 \pm 3.0^{\circ}$ \\
\hline Oluecosa, 120 arind (momoly & $5.1 \pm 1.2$ & $90 \pm 0.9^{*}$ & $14.4 \pm 3.9^{40}$ \\
\hline 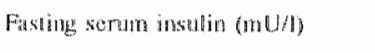 & $9.9(5.3-22.1)$ & $17.4(5.8-41.9)^{\circ}$ & $20(5.8 .55 .5)^{*}$ \\
\hline Scrage mollin 120 min dounty & $55(10.5-180: 6)$ & $191.4(28.3-1874)$ & $194.2(17.0-532.7)^{*}$ \\
\hline 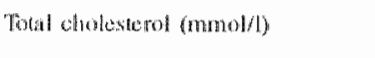 & $6.6 \pm 12$ & $6.6+1.1$ & $6.4 \pm 1.1$ \\
\hline HOL chalesterol (minoly) & $1.3 \pm 10.4$ & $1.3 \pm 0.3$ & $1.3+0.3$ \\
\hline Trighlyeriates (monoly) & $1.4(0.8-11.3)$ & $1.4(0.7-3.6)$ & $1.4(0.6-3.0)$ \\
\hline 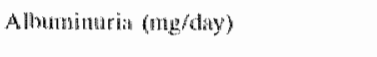 & $5.4(1.3-261)$ & $6.5(1.4-105)$ & $7.3(2.1-685)$ \\
\hline Retinevatiny & none & $\mid M: 2 F$ & $2 \mathrm{M}: 2 \mathrm{~F}$ \\
\hline $\mathrm{PAB}$ & $\mathbb{N} A: A F^{*}$ & $2 M: 4 F$ & $5 \mathbb{M}: 3 \mathbb{F}$ \\
\hline Anginta pectorix & none & $1 \mathrm{M}: 3 \mathrm{~F}^{\mathrm{F}}$ & $2 \mathrm{M}: \mathrm{IF}$ \\
\hline 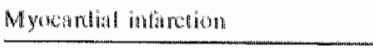 & gionts & $1 \mathrm{P}$ & $4 \mathrm{M}: \| \mathrm{F}$ \\
\hline
\end{tabular}

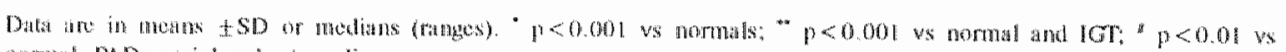
nomil. PAD: peringhat artery discase.

Fasting blood samples for this cross-sectional survey were collected in tubes containing sodium citrate $3.25 \%$ (dilution 1:10) for determining TFPI activity, VWF antigen, thrombomodulin, t-PA antigen and PAI-1 activity, glycated hemoglobin $\left(\mathrm{Hb} \mathrm{A}_{\mathrm{lc}}\right)$ and lipid profile at baseline.

TFPI activity was measured using the chromogenic substrate assay according to Sandset after polybrene pretreatment (expressed in \% with regard to standardized TFPI activity, measured in a plasma pool obtained from 45 healthy donors with a mean age $36 \pm 5$ years; $C V 7.4 \%$ at $100 \%$ level in our laboratory). In vivo 
thrombin formation was assessed by determination of prothrombin fragments $\Gamma_{1+2}$ using ELISA (Enzygnost Behring, Marburg, Germany; intra-assay CV 5-7.5\%. interassay CV 6-13\%). Plasma levels of WWF antigen were determined by an ELISA method using rabbit anti-human vWF (Dako A/S, Denmark; CV 7\%; normal range 60-180\%). Thrombomodulin (Diagnostica Stago, France; CV 8\%; mean $24 \mathrm{ng} \mathrm{ml}^{-1}$ ) and t-PA antigen (Innogenetics, Belgium; CV 7\%; normal range 1.3-10.4 $\mathrm{ng} \mathrm{m}^{-1}$, mean $4.1 \pm 2.4 \mathrm{ng} \mathrm{m}^{-1}$ ) were measured by enzyme immunoassay. PAI-1 activity was photometrically measured (Kabi Diagnostica, Sweden; intraassay $\mathrm{CV} 6 \%$; normal range $1-20 \mathrm{AU} \mathrm{ml}^{-1}$, median $\left.8 \mathrm{AU} \mathrm{ml}^{-1}\right)$. HbA $\mathrm{Ac}_{\text {ic }}$ was measured by high-performance liquid chromatography (Diamat, Bio-Rad, USA). Serum total and HDL-cholesterol and triglycerides were determined with enzymatic methods (Unimate 5 and 7, Roche, Basle, Switzerland), and apo $A_{1}$ and apo B were measured with immunoturbidimetry (Uni-kit, Roche). An enzymatic hexokinase method (Unimate 5, Roche) was used for measuring serum glucose concentrations. Serum free insulin was measured with a double antibody radioimmunoassay after polyethylene glycol pretreatment (Pharmacia Diagnostics; within-assay $\mathrm{CV} 3.4-6.1 \%$ in the range of $\left.3-50 \mathrm{mU} \mathrm{I}^{-1}\right)$. For determination of urinary albumin an immunoturbidimetric technique was applied (Uni-kit, Roche; interassay CV $3 \%$ ).

\section{Statistics}

All data are expressed as mean $\pm \mathrm{SD}$ or as median and range when not normally distributed. For comparing more than two groups, analysis of variance (ANOVA) with Student-Newman-Keuls correction for multiple comparisons was used. If data were not normally distributed, the Kruskall-Wallis analysis of variance was applied. Categorical variables were analyzed by the chi-square test. Multivariate logistic regression analyses (based on the maximum-likelihood method) were used to investigate the association of TFPI activity with other endothelium-dependent parameters and cardiovascular risk factors. P-values $\leq 0.05$ were considered statistically significant.

\section{Results}

There were no statistically significant differences in gender between the NGT, IGT and diabetic group (Table 6.1). The mean age, body mass index, and the systolic blood pressure of the NGT subjects were significantly lower than of the subjects with IGT and diabetes. The diastolic blood pressure was significantly higher in the IGT subjects in comparison with the NGT subjects. Serum insulin levels were 
higher in the IGT and diabetic group compared to the NGT group. No differences in serum insul in levels were found between the IGT and diabetic subjects. The lipid profile was similar in the three groups.

Since TFPI activity, t-PA antigen, PAI 1 activity and VWF antigen increase with age, the results were adjusted for age ${ }^{19,23,24}$. Compared to the NGT subjects, WWF antigen, t-PA antigen, and PAI-I activity were all significantly higher in the IGT and diabetic subjects (Table 6.2). TFPI activity was increased in all groups as compared to the younger healthy volunteers, from which the standardized plasma pool was obtained. The TFPI activity was highest in the diabetic patients, while it was higher in the IGT group in comparison with the NGT group. However, the differences were small and of borderline statistical significance. Thrombomodulin levels showed the same pattern. Albumin excretion rate was not different between the three groups. In total, 17 subjects had microalbuminuria, of which 4 subjects had NGT, 4 subjects IGT and 9 subjects had diabetes. One diabetic subject had macroalbuminuria. Also with regard to the procoagulant state, as measured by the prothrombin $\mathrm{F}_{1+2}$ fragments, the three groups did not differ.

Table 6.2 Hemostatic endothelium-dependent factors and abuminuria by catagories of glucose intolerance.

\begin{tabular}{|c|c|c|c|}
\hline & Normal & $\lim \Gamma$ & Type 2 diabetes \\
\hline TFPl-ract (第) & $111 \pm 16$ & $\| 13 \pm 15$ & $116 \pm 16$ \\
\hline WWF (W) & $127 \pm 30$ & $179 \pm 44^{\circ}$ & $168 \pm 63^{\circ}$ \\
\hline i. $P A \quad(n g / 1)$ & $10.7 \pm 3.5$ & $14.0 \pm 4.2^{*}$ & $15.4+5.8$ \\
\hline $\mathrm{PAI}-1$ (AU/D) & $13(2-26)$ & $23(3-53)^{4 *}$ & $16(2-60)^{\circ}$ \\
\hline TM & $39.7 \pm 10.3$ & $44.9 \pm 12.8$ & $41.8 \pm 15.7$ \\
\hline$F_{1,2}$ & $1.85(0.544 .31)$ & $1.98(0.49-13.57)$ & $10.47(0.18-13.57)$ \\
\hline
\end{tabular}

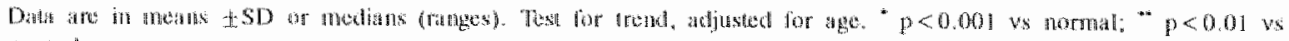
metritiul.

When correlating the different hemostatic endothelium-dependent factors with the metabolic parameters, it appeared that TFPI activity, vWF antigen and PAI-1 activity were significantly positively correlated with $\mathrm{HbA}_{1 \mathrm{c}}$ (Table 6.3). These correlations however were moderate. There was a correlation between fasting blood glucose and $V W F$ antigen, $t-P A$ antigen and PAl- 1 activity, while serum insulin was strongly correllated with $v W F$ antigen $(r=0.34), t-P A$ antigen $(r=0.60)$ and PAI- 1 activity $(r=0.47)$. Total cholesterol was only correlated with PAI-1 activity. In addition, there was a negative correlation between HDL-cholesterol and t-PA antigen, PAI- 1 activity and thrombomodulin. PAI-1 activity and R-PA antigen were positively associated with triglycerides. The partial correlation coefficients between the various endothelial-dependent factors and cardiovascular risk factors are 
depicted in Table 6.4. Besides TFPI activity, wWF antigen and PAI-1 activity were positively correlated with the urine albumin excretion. Table 6.5 shows the interrelationships between the endothelium-dependent factors. PAI-1 activity and thrombomodulin were associated with VWF antigen and t-PA antigen, while the latter was also correlated with WWF antigen. There appeared to be a borderline correlation between TFPI activity and WWF antigen and PAI- 1 activity.

Table 6.3 Correlations between endotheliam-dependent tactors and metabolic parameters.

\begin{tabular}{|c|c|c|c|c|c|c|}
\hline & TFPI & FWF & $t-P A$ & PAII 1 & TM & $\mathrm{F}_{1+2}$ \\
\hline$H \mathrm{HA}_{\mathrm{k}}$ & $0.18^{\circ}$ & $0.20^{\prime \prime}$ & $0,17^{*}$ & $0.16^{\circ}$ & -0.11 & -0.11 \\
\hline Gilucose & $0.15^{8}$ & $0.23^{* *}$ & $0.25^{\mathrm{m*}}$ & $0.32^{6+0}$ & -0.09 & .0 .00 \\
\hline Insulin & 0.11 & $0.34^{* *}$ & $0.60^{+\infty+\infty}$ & $0.47^{40 *}$ & 0.05 & $-0,00$ \\
\hline Thiall cholestero] & 0.04 & -0.10 & 0.01 & $0.16^{*}$ & 0.12 & 0.03 \\
\hline HDL-cholesterol & -.001 & -0.12 & $-0.33^{3 *}$ & $-0.22^{*+}$ & $0.16^{\circ}$ & -0.07 \\
\hline Triglycerides & 0.07 & 0.02 & $0.21^{\circ}$ & $0.30^{+44}$ & 0.03 & -0.04 \\
\hline
\end{tabular}

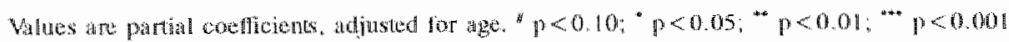

Table 6.4 Correlations between endothelium-dependent factors and cardiowascular risk factors.

\begin{tabular}{|c|c|c|c|c|c|c|}
\hline & TFPI & wWF & $t+\|^{x}$ & PAI-I & $\mathrm{TM}$ & $F_{i+2}$ \\
\hline Systolic blood pressume & 0.05 & 0.02 & 0.08 & $0.17 \%$ & 0.11 & 08.10 \\
\hline Diastolic bood pressure & 0.03 & 0.01 & 0.04 & $0.17^{*}$ & 0,01 & $0.19^{\circ}$ \\
\hline Albuminuria & $0.16^{*}$ & $0.21^{*}$ & $0.116^{*}$ & $0.22^{* *}$ & 0.13 & 40.02 \\
\hline Body Mass Index & 0.04 & $0.20^{\circ}$ & $0.42^{* * \infty}$ & $0.45^{\circ * *}$ & 0.09 & 0.13 \\
\hline
\end{tabular}

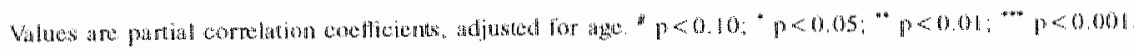

Table 6.5 Correlations between endothelium-dependent factors.

\begin{tabular}{|c|c|c|c|c|c|}
\hline & TFPI & VWF & $A-\|^{\mathbb{A} A}$ & PAI 1 & $\mathrm{TM}$ \\
\hline WWF & $0.14^{\prime}$ & & & & \\
\hline $\mathrm{AFA}$ & 0.02 & $0.42^{n+t}$ & & & \\
\hline PAI-I & $0.14^{87}$ & $0.25^{* *}$ & $0.48^{20+4}$ & & \\
\hline $\mathrm{TM}$ & -0.05 & $0.22^{\circ *}$ & $0.18^{\circ}$ & 0.0 .4 & \\
\hline$F_{1 \cdot z}$ & 0.002 & -0.03 & 0.03 & $-0,09$ & 0.10 \\
\hline
\end{tabular}

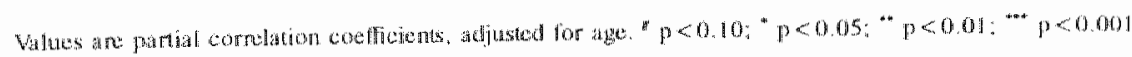




\section{Discussion}

Atherosclerotic changes of the arterial vascular bed is one of the main events of ageing. Disturbances in glucose metabolism accelerate this process of atherosclerosis. Since endothelial damage plays a central role in the pathogenesis of cardiovascular disease, we have investigated several endothelium-dependent hemostatic factors in the present study. One may thereby assume that in subjects with a disturbed glucose metabolism more vascular endothelial dysfunction is present in comparison with age-matched healthy controls. More vascular dysfunction may hereby be reflected by higher levels of circulating endotheliumderived factors.

We observed significantly increased levels of VWF antigen, t-PA antigen, and PAI$I$ activity in the IGT group as well as in the diabetic group as compared to the eldery with NGT. This confirms earlier reports, in which it was also suggested that these alterations were the result from damage of endothelial cells ${ }^{25}$. Since there were no differences between the IGT and diabetic group, the increases in levels of WWF antigen, I-PA antigen and PAI-1 activity could suggest that part of the endothelial damage may already occur in the prediabetic phase. This may explain the reported increased incidence of cardiovascular disease in these two groups. It is known that the levels of VWF antigen, t-PA antigen and PAI- 1 activity are influenced by glucose metabolism ${ }^{26-28}$. As compared to the NGT group, fasting glucose was highest in the IGT and diabetic group, while glycated hemoglobin was significantly higher in the type 2 diabetic subjects. Correlation analysis indeed not only showed a positive association between $\mathrm{HbA}_{\mathrm{Ic}}$ and $\mathrm{VWF}$ antigen, but between fasting blood glucose and $\mathrm{VWF}$ antigen, t-PA antigen and PAI-1 activity as well. In addition, serum insulin correlated also with these three endothelial hemostatic factors. Especially, there was a strong relation between insulin levels and PAI-1 activity and I-PA antigen, which remained after further adjustment for serum gtucose and $\mathrm{HbA}_{\mathrm{fc}}$. These findings suggest that higher insulin levels, and therefore probably insulin resistance, are associated with impaired fibrinolysis in elderly subjects with or without diabetes mellitus.

Thrombonodulin levels were increased in the three groups, but no differences between the groups could be demonstrated. However, thrombomodulin did not correlate with the risk factors or any of the metabolic parameters with the exception of HDL-cholesterol. This is in contrast with earlier reports ${ }^{15}$.

Although we found a slightly higher TFPI activity in the IGT and diabetes groups, this difference was not statistically significant. However, we were able to demonstrate a significant association between TFPI activity and $\mathrm{HbA}_{\mathrm{lc}}$. This is in agreement with the findings of Kario et al, who also found increased TFPI antigen levels in type 2 diabetic patients, especially with overt alburninuria, compared to 
healthy controls $s^{7}$. In the present study, a significant correlation between TFPI activity and the albumin excreion rate could also be demonstrated. Since microalbuminuria is a sign of generalized angiopathy, TFPI may be a marker of this condition. The same correlation could also be demonstrated between albuminuria and VWF antigen and PAI-1 activity. However, in comparison with type 1 diabetes, type 2 diabetes is considered to be a different disease regarding vascular complications. While type 2 diabetes is characterized by the occurrence of macrovascular complications, in type 1 diabetic patients mainly microvascular complications are observed before macrovascular abnomalities occur. TFPI expression is restricted to the endothelium of the microvasculature and is not believed to be synthesized by the endothelium of larger vessel $s^{29}$. This may partly explain why in the present study no significant differences between the diabetic and NGT group are found. In addition, the elderly subjects in the present study population appeared to be relatively free of cardiovascular disease. Besides, only a total of 17 subjects in all three groups had microalbuminuria, while 1 subject with diabetes had macroalbuminuria. The presence of extensively generalized angiopathy would therefore be less likely. Others found increased levels of TFPI only in type 2 diabetic patients with overt albuminuria ${ }^{17}$.

It is widely accepted that in patients with diabetes, a procoagulant state can be found $^{30,31}$. Because TFPI is a congulation inhibitor, one may suggest that TFPI activity is influenced by this procoagulant state. In the present study, we were unable to show a difference in procoagulation, as measured by the prothrombin $F_{1+2}$ fragments, between the three groups. There was also no significant correlation between TFPI activity and the $F_{1+2}$ fragments in this patient population. Others were also unable to demonstrate a correlation between TFPI and factor VIIa levels ${ }^{17}$. In addition, we could not find a relation between $F_{1+2}$ and the other endothelial hemostatic factors.

Dyslipidenia is a well recognized risk factor for cardiovascular disease in IGI and type 2 diabetic subjects ${ }^{4.6}$. Because TFPI in plasma is mainly associated with lipoproteins, especially with LDL and HDL ${ }^{2024}$, TFPI activity could be influenced by the levels of lipoproteins. The levels of lipoproteins were similar in the three groups, and no significant relationship between TFPI activity and lipids was found. This is in agreement with our earlier report on type 1 diabetic patients, while others have found a positive relation in nondiabetic hypercholesterolemic subjects $^{15.32}$. Only PAI-1 activity was associated with total cholesterol, while there was a negative correlation between HDL-cholesterol and I-PA antigen, PAI-1 activity and thrombomodulin.

The endothelium-dependent factors are also known to be affected by blood pressure $^{33.35}$. The systolic blood pressure was higher in the IGT and diabelic subjects, while the diastolic blood pressure was higher in the IGT group. However, the systolic and diastolic blood pressure were only positively correlated with PAI-I 
activity. Obesity is another well known risk factor for cardiovascular complications ${ }^{36}$. The BMI was higher in the IGT and diabetic group. In addition, a significant positive correlation between BMI and t-PA antigen, PAI-1 activity and VWF antigen could be demonstrated. This is in concordance with the findings of earlier studies ${ }^{37-39}$.

We conclude that several hemostatic endothelium-dependent factors are already increased in elderly subjects, relatively free of cardiovascular disease, with impaired glucose tolerance, which is believed to precede the development of type 2 diabetes mellitus. This seems to be especially true for VWF antigen, t-PA antigen and PAI-I activity. TFPI activity and thrombomodulin levels were increased in all elderly subjects with a normal or impaired glucose tolerance and type 2 diabetes mellitus, but there were no differences between the groups. 


\section{References}

1. Kannel WB, Garrison RJ, Wilson PWF. Obesity and nutrition in elderly diabetic patients. Am J Med 1986;80(S5A):22-30.

2. Agner E, Thorsteinsson B, Eriksen M. Impaired glucose tolerance and diaberes mellitus in elderly subjects. Diabetes Care 1982;5:600-4.

3. Harris MI, Hadden WC, Knowler WC, Bennett PH. Prevalence of diabetes and impaired glucose tolerance and plasma glucose levels in U.S. population aged 20-74 yr. Diabetes 1987;36:523-34.

4. Mykkänen L, Laakso M, Pyörälä K. Asymptomatic hyperglycemia and atherosclerosic vascular disease in the elderly. Diabetes Care 1992;15:1020-30.

5. Wingard DL, Barrett-Connor EL, Sicheidt-Nave C, McPhillips JB. Prevalence of cardiovascular and renal complications in older adults with normal or impaired glucose tolerance or NIDDM. Diabetes Care 1993;16:1022-5.

6. Parving HH, Gall MA, Nielsen FS. Dyslipidaemia and cardiovascular disease in non-insulin-dependent diabetic patients with and without diabetic nephropathy. $J$ Intern Med (S) 1994;736:89-94.

7. Schmitz A, Vaeth M, Mogensen CE. Systolic blood pressure relates to the rate of progression of albuminuria in NIDDM. Diabelologia 1994;37:1251-8.

8. Gall MA, Borch-Johnsen K, Hougaard P. Nielsen FS, Parving HH. Albuminuria and poor glycemic control predict mortality in NIDDM. Diabetes 1995;44:1303-9.

9. Yudkin JS, Forrest RD, Jackson CA. Microalbuminuria as predictor of vascular disease in non-diabetic subjects. Lancet 1988;ii:530-3.

10. Neil A, Hawkins M, Potok M, Thorogood M, Cohen D, Mann J, A prospective population-based study of microalbuminuria as a predictor of mortality in NIDDM. Diabetes Care 1993;16:996-1003.

11. Mattock MB, Morrish NJ, Viberti G, Keen $H$, Fritzgerald AP, Jackson G. Prospective study of microalbuminuria as predictor of mortality in NIDDM. Diabetes 1992;41:736-41.

12. Damsgaard EM, Froland A, Jorgensen OD, Mogensen CE. Microalbuminuria as a predictor of increased mortality in elderly people. BMJ 1990;300:297-300.

13. Kuusisto J, Mykkanen L, Pyorala K. Laakso M. Hyperinsulinemic microalbuminuria. A new risk indicator for coronary heart clisease. Circulation 1995;91:831-7.

14. Stehouwer CD, Nauta Jj, Zeldenrust GC, Hackeng WH, Donker AJ, den Otolander GJ. Urinary albumin excretion, cardiovascular disease, and endothelial dysfunction in non-insulin-dependent diabetes mellitus. Lancet 1992;340:319-323.

15. Collier A, Rumley A, Rumley AG, Paterson JR, Leach JP, Lowe GD, Small M. Free radical activity and hemostatic factors in NIDDM patients with and without microalbuminuria. Diabetes 1992;41:909-13. 
16. Leurs PB, van Oerle $R$, Hamulyăk $K$, Wolffenbuttel BHR. Tissue factor pathway inhibitor activity in patients with IDDM. Diabetes 1995:44:804.

17. Kario K, Matsuo T, Kobayashi H, Matsuo M, Sakata T, Miyata T. Activation of tissue factor-induced coagulation and endothelial dysfunction in non-insulin clependent diabetic patients with microalbuminuria. Arterioscler Thromb Vasc Biol $1995: 15: 1114-20$.

18. Leurs PB, van Oerle $R$, Wolffenbuttel BHR. Hamulyák $K$. Increased tissue factor inhibitor and coagulation in patients with insulin-dependent diabetes mellitus. Thromb Haemostas 1997;77:472-6.

19. Lindahl AK, Sandset PM, Abildgard U. The present status of tissue factor pathway inhibitor. Blood Coagul Fibrinolysis $1992 ; 3: 439-49$.

20. Wowotny WF, Girand TJ, Miletich JP, Broze GJ. Purification and characterization of the lipoprotein-associated coagulation inhibitor from human plasma. If Biol Chem $1989 \cdot 264: 188832-7$.

2. Lesnik P, Vonica A, Guerin M, Moreau M, Chapman MJ. Anticoagulant activity of tissue factor pathway inhibitor in human plasma is preferentially associated with dense subspecies of LDL and HDL and with Lp(a). Atheroscler Thromb $1993 ; 13: 1066-75$.

22. Hofman A, Grobbee DE, de Jong PTVM, vam de Ouweland FA. Determinants of disease and disability in the elderly: the Rotterdam Elderly Sudy. Eur I Epidemiol $1991 ; 7: 403-22$.

23. Haverkate $F$, Thompson SG, Duckert F. Haemostasis factors in angina pectoris; relation to gender, age and acute-phase reaction. Thromb Haemost 1995;73:561-7.

24. Ariëns RAS, Coppola $\mathbb{R}$, Potenza I, Mannucci PM. The increase with age of the components of tissue factor coagulation pathway is gender-dependent. Blood Coagul Fibrinol 1995:6:433-7.

25. Collier A, Rumley A, Rumley AG, Paterson JR, Leach JP, Lowe GDO, Small M. Free radical activity and hemostatic factors in NIDDM patients with and without microalbuminuria. Diabetes 1992;41:909-13.

26. Gonallez I, Colwell A, Sarji KE, Nair RMG, Sagel I. Effect of metabolic control with insulin on plasma von Willebrand factor activity (VIII R:vWF) in diabetes mellitus. Thromb Res 1980;17:261-6.

27. Juhan Vague 1, Vague P, Poisson C, Aillaud MF, Mendex C, Collen D. Effect of 24 hours of normoglycaemia on tissue-type plasminogen activator plasma levels in misulindependent diabetes. Thromb Haemostas 1984;51:97-8.

28. Bathu $Y$, Kesteven $P$, Alberti $K G$, Walker $M$. Decreased plasminogen activator inhibitor-1 activity in newly diagnosed type 2 diabetic patients following dietary modification. Diabet Med 1993;10:802-6.

29. Osterud B, Bajaj MS, Bajaj SP. Sites of tissue factor pathway inhibitor (TFPI) and tissue factor expression under physiologic and pathologic conditions. On behalf of the Subcommittee on Tissue Factor Pathway Inhibitor (TFPl) of the Scientific and Standardization Commitre of the ISTH. Thromb Haemostas 1995;73:873-5. 
30. Ostermann H, van de Loo J. Factors of the hemostatic system in diabetic patients. A survey of controlled studies. Haemostasis $1986 ; 16: 386-416$.

31. Cammassi F, Morale M, Pucetti R, De Negri F, Monzani F. Navalesi R, Marrani $G$. Coagulation and fibrinolytic system impairment in insulin-dependent diabetes mellitus. Throm Res 1992;67:643-54.

32. Sandset PM, Lund H, Norseth J, Abildgaard U, Ose L. Treatment with hydroxymethylglytaryl-coenzyme A reductase inhibitors in nypercholesterolemia induces changes in the components of the extrinsic coagularion system. Arterioscler Thromb $1991 ; 11: 138-45$.

33. Gleerup G, Winther K. Decreased fibrinolytic activity and increased platelet function in hypertension. Possible influence of calcium antagonism. Am J Hypertens $1991 ; 4: 168 S-71 \mathrm{~S}$.

34. Landin $K$, Tengborn L, Smith U. Elewated fibrinogen and plasminogen activator inhibitor (PAL-1) in hypertension are related to metabolic risk factors for cardiowascular disease. J Intern Med 1990;227:273-8.

35. Blann AD, Naqui $T$, Waite M, McCollum CN. Von Willebrand factor and endothelial damage in essential hypertension. I Hum Hypertens 1993; 7: 107-11.

36. Hubert HB, Feinleib M, McNamara P, Castelli WP. Obesity as an independent risk factor for cardiovascular disease: a 26 -year follow-up of participants in the Framingham Heart Study, Circulation 1983;67:968-77.

37. Potter van Loon BI, Kluft. C, Radder JK, Blankenstein MA, Meinders AE. the cardiovascular risk factor plasminiogen activator inhibitor type 1 is related to insulin resistance. Metabolism 1993;42:945-9.

38. Landin K, Stigendal L, Eriksson E, Krotkiewski M, Risberg B, Tengborn L, Smith U. Abdominal obesity is associated with impaired fibrinolytic activity and elevated plasminogen activator inhibitor-1. Metabolism 1990;39:1044-8.

39. Blann AD, Bushell D, Davies A, Faragher EB, Miller JP, McCollum CN. Von Willebrand factor, the endothelium and obesity. In $\mathcal{J}$ Obesity 1993;17:723-5. 


\section{Chapter 7}

Tissue Factor Pathway Inhibitor (TFPI) release from cultured endothelial cells under normo- and hyperglycemic conditions

PB Leurs, $R$ van Oerle, $T$ Lindhout, BHR Wolffenbuttel, K Hamulyák 


\begin{abstract}
It has recently been demonstrated that basal and postheparin TFPl activity is increased in patients with diabetes mellitus. In order to find an explanation for these in vivo observations, an in vitro study was performed, using an immortalized human endothelial cell (EC) line (EA.hy 926). After the cells were cultured in the presence of varying concentrations of D-glucose and insulin, the cells were incubated for 10 minutes with unfractionated heparin. Then, TFPI activity was measured in the supernatant and at the EC surface. Postheparin TFPI activity in the supernatant increased with increasing heparin concentrations up to $0.6 \mathrm{U} / \mathrm{ml}$. The time course of TFPI release using $0.5 \mathrm{U} / \mathrm{ml}$ heparin showed a rapid release during the first 10 minutes. Interestingly, the cell-bound TFPI activity decreased as expected during that time period, but not further than $35 \%$, in spite of prolonged incubation time. Postheparin TFPI release, but not basal TFPI activity, was higher in EC cultures with $35 \mathrm{mmol} / \mathrm{D}$-glucose than from EC cultured with $7 \mathrm{mmol} / \mathrm{I}$ D-glucose $(p<0.001)$. This difference was not due to a change in osmolarity or number of cells. Postheparin TFPI activity in EC cultures was positively correlated with glucose $(r=0.28, p<0.05)$. In high glucose $\mathrm{EC}$ cultures with low insulin concentrations postheparin TFPI activity was increased, while high insulin concentrations had the opposite effect. In low glucose EC cultures, insulin had no effect on postheparin TFPI activity. High glucose levels may be an explanation for these findings since they could cause glycation of glycosaminoglycans at the endothelial cell surface, which in turn could result in altered binding characteristics of TFPI to these glycosaminoglycans.
\end{abstract}




\section{Introduction}

The vascular endothelium can be regarded as a paracrine organ which regulates hemostasis (coagulation and fibrinolysis). The fact that blood does not form clots continuously as it passes over the endothelial cell surface indicates that in homeostasis anticoagulant mechanisms predominate over procoagulant processes". The endothelium expresses factors associated with anticoagulant properties such as heparan sulfate, thrombomodulin and tissue factor pathway inhibilor (TFPl $)^{1.3}$. Besides, it can directly influence vascular fibrinolysis through the synthesis of fibrinolytic components that promote or inhibit fibrinolysis (respectively tissue plasminogen activator (t-PA) and plasminogen activator inhibitor-1 (PAl-1) $)^{1}$.

In 1987 TFPI, a Kunitz-type coagulation inhibitor, was indentified as a single protein ${ }^{4.5}$. The TFPI gene has been localized on chromosome $2 q^{6}$. TFPI inhibits factor Xa and in complex with factor Xa also the factor VIla/tissue factor catalytic complex. The major site of production is the vascular endothelium ${ }^{3}$. Of TFPI $50-90 \%$ is bound to the endothelium, probably by glycosaminoglycans, $10-50 \%$ in plasma and $2-3 \%$ in platelets. Only about $5 \%$ of the TFPI in the plasma circulates as a free, uncomplexed protein ${ }^{8}$. Release from the endothelial cell surface can be stimulated by glycosaminoglycans with greater binding affinity to TFPI like heparin".

Diabetes mellitus is associated with premature atherosclerosis. Endothelial damage has thereby been considered as the initiating event in the pathogenesis of atherosclerosis ${ }^{10.11}$. Disturbances in hemostatic parameters in diabetic patients play a role in the development of cardiovascular complications. Until now little is known about TFPI activity in diabetic subjects. Previously, we have performed a study concerning TFPI activity in the basal state and after intravenous administration of heparin in IDDM patients in comparison to healthy controls ${ }^{2}$. An increased basal and postheparin TFPI activity was found in the IDDM patients as compared to the controls, related to poor metabolic control. This increase in TFPI activity may be the result of functional vascular endothelial damage. An increased TFPI activity as a counteraction to the procoagulant state seen in diabetic patients could not be demonstrated $^{13}$. However, altered binding characteristics of TFPI to glycosaminoglycans at the endothelial cell surface, due to chronic hyperglycemia, could play a role.

Because hyperglycemia and hyperinsulinemia are found in diabetic patients, we performed several in vitro studies to evaluate TFPI activity in cultures of human endothelial cells under different in vitro conditions, comparable with different metabolic conditions as can be seen in diabetic patients. TFPI activity was not only measured in the supernatant but also indirectly at the endothelial cell surface as well. A human endothelial hybrid cell line, EA.hy 926, was used, which has 
already been evaluated regarding the expression of TFPI and other endotheliumdependent parameters, such as von Willebrand factor, thrombomodulin, t-PA and PAI-1.14.16.

\section{Material and Methods}

\section{Materials}

The culture medium RPMI 1640 (code 42402) and Medium 199 (code 41150) were purchased from Gibco, the 24 Falcon multiwell dishes $\left(2 \mathrm{~cm}^{2} /\right.$ well) from Micronic. The polyclonal rabbit anti-human TFPI antibodies were kindly provided by 0 Nordfang, Novo Nordisk, Denmark. The bovine factor X, D-glucose, sorbitol and insulin were obtained from Sigma, and human thromboplastin from Behring. The chromogenic substrate S2765 was purchased from Chromogenix, the unfractionated heparin from Leo.

\section{Cell cuitures}

An immoralized human endothelial cell (EC) line (EA.hy 926; kindly provided by CJS Edgell, USA) was used. A mixture of $20 \mathrm{ml}$ RPMI 1640 (20 $\mathrm{mM}$ Hepes, 10 $\mathrm{mM}$ bicarbonate) and $20 \mathrm{ml}$ Medium $199(26 \mathrm{mM}$ bicarbonate, $148 \mathrm{mM}$ L-alanyl glutamine) was used as a primary medium, to which $6 \mathrm{ml}$ of fetal calf serum, $1 \mathrm{ml}$ of HAT (mixture of $100 \mathrm{mmol} / \mathrm{ml}$ hypoxanthine, $0.4 \mathrm{mmol} / \mathrm{ml}$ aminopterine and 16 $\mathrm{mmol} / \mathrm{ml}$ thymidine), $1 \mathrm{ml}$ of L-alanyl glutamine $(200 \mathrm{mM})$, and $0.5 \mathrm{ml}$ of a mixture of penicillin $(10.000 \mathrm{U} / \mathrm{ml})$, streptomycin $(10.000 \mathrm{U} / \mathrm{ml})$ and fungizone $(25$ U/ml) was added. Before use, the complete culture medium was filtered by a sterilizing filter (Minisart, Satorius; pore-width $0.20 \mu$ ).

The experiments were performed on confluent EC layers, cultured in 24 multiwell dishes $\left(2 \mathrm{~cm}^{2} /\right.$ well), In a $5 \% \mathrm{CO}_{2}$ stove, cells were cultured at $37^{\circ} \mathrm{C}$ in wells containing $0.5 \mathrm{ml}$ of medium. The endothelial cells were seeded in such a density that confluency was not reached earlier than after 5 days. When not stated otherwise, the cell culture medium was not refreshed during culturing.

\section{Cell counts}

The cell cultures at confluency were washed twice with phosphate-buffered saline (PBS). Thereafter, the cells were harvested by uncubation with $0.05 \%$ trypsin EDTA $0.02 \%$ (ICN). The trypsin was removed after centrifugation (1200 RPM, 5 min), while the cell pellet was resuspended in primary medium solution. Cell 
counts of cultures were then performed, using a cell count chamber (Bürker-Turk; Optik-Labor).

\section{Measurements of TFPI activity}

TFPI activity in the supernatant was measured chromogenically according to Sandset ${ }^{17}$. TFPI activity was also measured at the EC surface. Confluent cell layers, cultured in 10 wells of a 24 multiwell dish $\left(2 \mathrm{~cm}^{2} /\right.$ well $)$, were rinsed with Hepes-buffer (Hepes $10 \mathrm{mmol} / \mathrm{l}, \mathrm{NaCl} 135 \mathrm{mmol} / \mathrm{KCl} 4 \mathrm{mmol} / \mathrm{K}, \mathrm{CaCl}_{2} 3$ mmol/1, $\mathrm{Mg}_{2} \mathrm{Cl} 1 \mathrm{mmol} / \mathrm{l}$, D-glucose $11 \mathrm{mmol} / \mathrm{l}$, bovine serum albumin (BSA) 25 $\mathrm{mg} / \mathrm{ml}, \mathrm{pH} 7.45)$ twice. Then each well was incubated with $100 \mu \mathrm{l}$ Hepes-buffer for $10 \mathrm{~min}$ at room temperature (step 1). In a control experiment, instead of Hepesbuffer, $10 \mu$ polyclonal rabbit anti-human TFPI antibodies in Hepes-buffer (concentration 1:200) was incubated for $10 \mathrm{~min}$ under the same conditions. After incubation Hepes-buffer and anti-TFPI were removed from the cell layers, $40 \mu \mathrm{l}$ of a mixture containing $50 \mathrm{mmol} / 1$ Tris. $\mathrm{HCl}, 0.1 \% \mathrm{BSA}, 10 \mathrm{mmol} / \mathrm{l}$ calcium, 2.5 nmol// bovine factor X, $2 \mathrm{mmol} / /$ factor VIla, and human thromboplastin (1:300) was added to all the wells except one, which also served as a control (step 2). To this well, Hepes-buffer was added. Subsamples $(25 \mu l)$ were taken after variable incubation times ( 1 to $25 \mathrm{~min}$ ) to measure residual factor VIIa/tissue factor activity in the supernatant. The multiwell dish was carefully shaken during the subsampling periode, using a thermostated microwell shaker. To the subsamples $65 \mu$ l bovine factor $\mathrm{X}(70 \mathrm{nmol} / \mathrm{l})$ was added and incubated for $15 \mathrm{~min}$ at $37^{\circ} \mathrm{C}$ (step 3). Hereafter, $50 \mu \mathrm{l}$ chromogenic substrate $\mathrm{S} 2765(0.8 \mathrm{mg} / \mathrm{ml})$ was added to the subsamples and incubated for $20 \mathrm{~min}$ at $37^{\circ} \mathrm{C}$ (step 4). The conversion of substrate was stopped with $50 \mu \mathrm{l}$ of $20 \%$ acetic acid and read off at $405 \mathrm{~nm}$. The measurement of TFPI activity at the endohelial cell surface was also performed after incubation with $0.5 \mathrm{U} / \mathrm{ml}$ heparin (step 1 , instead of Hepes-buffer) for $10 \mathrm{~min}$ at $37^{\circ} \mathrm{C}$.

\section{Osmolarity experiment}

Osmolarity studies were done, using D-glucose and sorbitol (30 and $60 \mathrm{mmol} / \mathrm{l}$ ). Osmolarity was measured by the freezing-point depression method (Fiske 2400 multisample osmometer, Fiske Associates, Norwood, USA). Glucose was measured by an enzymatic hexokinase method (Unimate 5 , Roche).

\section{Heparin incubation experiments}

After rinsing the confluent $\mathrm{EC}$ layer twice with Hepes-buffer, the cell culture was incubated with $200 \mu(0.5 \mathrm{U} / \mathrm{ml})$ of unfractionated heparin (Leo) in Hepes-buffer during 10 minutes at $37^{\circ} \mathrm{C}$, unless stated otherwise. 


\section{Statistics}

All data are expressed as mean $\pm S D$. For comparing two groups the $t$-test was applied, while in case of comparing more than two groups, one-way analysis of variance (ANOVA) with Student-Newman-Keuls correction for multiple comparisons was used. In case of repeated measurements in time a multiple analysis of variance (MANOVA) for repeated measurements was performed. P-values $\leq 0.05$ were considered statistically significant. The correlation coefficient was also determined by regression analysis.

\section{Results}

\section{Heparin-dependent TFPI release from cultured endothelial cells}

To establish the time-dependency of TFPI release, day 1 confluent EC layers were rinsed with Hepes-buffer and incubated with heparin $(0.5 \mathrm{U} / \mathrm{ml})$ for variable time intervals ( 1 to 30 minutes; $n=12$, Figure $7.1 \mathrm{~A}$ ). It is apparent that TFPI activity increased rapidly during the first 10 minutes. After that a much slower release was observed. Therefore, we also indirectly measured the TFPI activity at the cell surface for several time intervals ( 1 to 25 minutes) with and without heparin. Figure $7.1 \mathrm{~B}$ clearly shows a rapid inactivation of the factor VIla/tissue factor complex, resulting in a decrease of residual activity in the supernatant to about $35 \%$. After heparin incubation, this decrease in residual factor VIla/tissue factor activity in the supernatant appeared to be somewhat less, suggesting that cell-bound TFPI can only be partially displaced by heparin under the conditions of the experiment. The specificity of this experiment was demonstrated by adding antihuman TFPI antibodies to the EC layers, resulting in no change of factor VIla/tissue factor activity in the supernatant. The time course of cell-bound residual TFPI activity appeared to be complementary with the time course of heparin releasable TFPI shown in Figure 7.1A.

Nexi, the optimal concentration of unfractionated heparin for TFPI release was investigated. After rinsing the confluent EC layer twice with Hepes-buffer, the cells were incubated with unfractionated heparin $(200 \mu \mathrm{l})$ of different concentrations (0 to $1.6 \mathrm{U} / \mathrm{ml}$ ) during 10 minutes at $37^{\circ} \mathrm{C}$. Figure 7.2 shows that heparin concentrations higher than $0.6 \mathrm{U} / \mathrm{ml}$ did not result in a further significantly higher TFPI release $(n=6)$. 


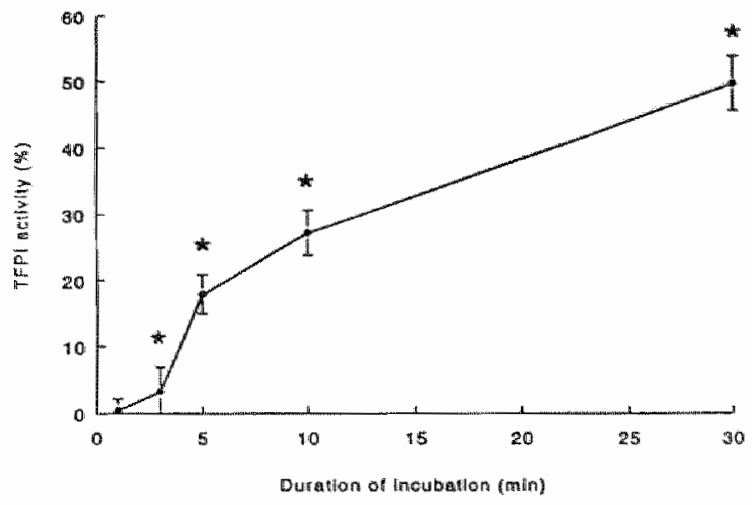

Figure 7.1A Timedependency of heparin-induced TFPI relesse. The influence of the duration of incubation with $0.5 \mathrm{U} / \mathrm{ml}$ heparin on TFPI release in cultured EC was studied by measuring TFPI activity in the supernatant after heparin incubation time intervals varying trom I to 30 minutes. $p<0.0001$ as compared to preceding metsurement.

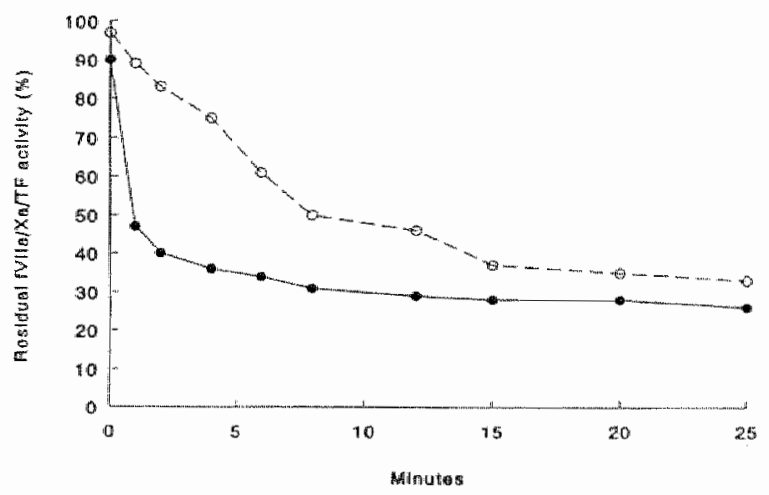

Figure 7.1B Time-dependency of the decrease in residual factor VIldXalTh aetivity un the supernatant before and after heparin incubation. The cell-bound TFPI activity was measured indirectly by measuring residual factor VIla/Xa/TF activity in the supernatant before $(\bullet$ and after $(0)$ heparin incubation. Confluent cell layers werte incubated with Hepes-buffer for 10 min a room temperature (step 1). After remowal of Hepes-bufter, a mixture of Tris.HCl. BSA. callcium, bovine factor $X(2.5$ nmol/1), factor Vlla and human thromboplastin was added (step 2). Thereafter, subsamples were taken after 1 to 25 minutes of incubation to measure residuall actor VIla/tissue factor activity. To these subsamples bowine factor $X(70$ mmolll) wass added and incubated for 15 min at $37^{\circ} \mathrm{C}$ (step 3). Finally chromogenic substrate $\$ 2765$ was added to the subsamples and incubated for 20 min at $37^{\circ} \mathrm{C}$. Conversiom of substrate was stopped and read oft at 405 nm. The procedure was also performed after incubation with $0.5 \mathrm{U} / \mathrm{ml}$ heparin (step $\|$, instead of Hepes-buffer). 


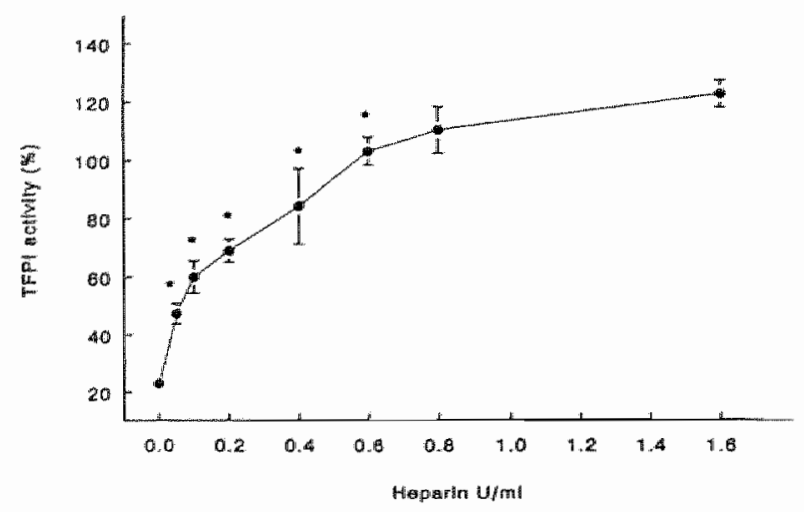

Figure 7.2 Heparin concentration and TFPI release. Influence of various heparin concentrations $(0$ to $1.6 \mathrm{U} / \mathrm{ml})$ on TFPI activity in EC cultures. Duration of incubation with hepanin: 10 min at $37^{\circ} \mathrm{C}$. $p<0.05$ vs preceding measurement.

Another variable that could determine the amount of TFPI that can be released by heparin from cultured endothelial cells is the 'culture-time'. Before heparin incubation, basal TFPI activity in the medium was significantly higher on day 4 postconfluent as compared to day $1 \quad(n=12 ; 1561 \pm 139 \%$ vs $1229 \pm 65 \%$, $\mathrm{p}<0.0001)$. The amount of TFPI that could be released from rinsed endothelial cells by heparin $(0.5 \mathrm{U} / \mathrm{ml}$; incubation time $\Perp 0$ minutes) was significantly higher for cells that were already confluent for 4 days as compared to cells that were only 1 day confluent $(n=9 ; 172 \pm 30 \%$ vs $99 \pm 14 \%, \quad p<0.0001)$. A significant correlation between pre- and postheparin TFPI activity $(r=0.54, p<0.0001)$ could also be demonstrated.

To see whether the postheparin TFPI activity is dependent on TFPI concentration in the medium, varying TFPl activities in the culture medium were obtained by adding nothing, fresh medium $(0.5 \mathrm{ml} /$ well) or 'old' (pre-grown) medium $(0.5 \mathrm{ml} /$ well) at day 3 of culture (Figure 7.3$)$. Old medium was obtained by removing the supernatant of 3 days old cell cultures. When the TFPI concentration in the supernatant was changed by adding fresh medium on day 3 of culture, significantly lower postheparin TFPI activity were found as compared to TFPI aclivity in medium that was not refreshed $(n=9 ; 98 \pm 6 \%$ vs $124 \pm 13 \%, p<0.001$ ) or in medium to which old medium was added $(n=9 ; 98 \pm 6 \%$ vs $114 \pm 10 \%$, $p<0.01)$. No difference was seen between no change of medium and the addition of old medium.

From the results of these initial experiments the following conditions were defined for further experimental work. Endothelial cells, one day after conffuency was reached, were rinsed twice with Hepes-buffer prior to incubation with Hepes-buffer containing $0.5 \mathrm{U} / \mathrm{ml}$ unfractionated heparin during 10 minutes at $37^{\circ} \mathrm{C}$. During 
culturing, no replacement or changing of the medium was allowed. Only when stated otherwise, all in vitro studies concerning the effects of glucose and insulin on TFPI activity were performed under these conditions.

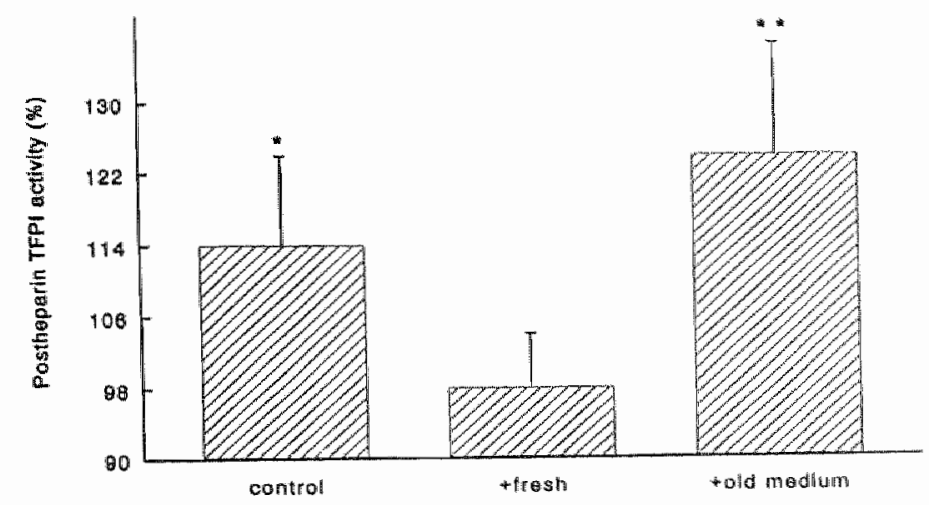

Figure 7.3 Influence of preheparin TFPI activity on postheparin TFPl release. The effect of different TFPI concentrations in the culture medium on postheparin TFPl activily is shown in this figure. The medium was not changed (contol) or either old (told medium) on fresh medium ( + fresh) was added on day 3 of culture. $*$ p<0.01 vs + fresh, ${ }^{*}$ * $\mathrm{p}<0.001 \mathrm{ws}+$ fresh.

\section{Effects of D-glucose and insulin on TFPI activity}

Different concentrations of D-glucose ( 7 and $35 \mathrm{mmol} / 1)$ were added to culture medium to study the effects of D-glucose on TFPI activity. Before heparin incubation, no difference in basal TFPI activity in the supernatant between low and high glucose cultures was seen $(n=12 ; 1229 \pm 65 \%$ vs $1109 \pm 47 \%$, NS). However, when rinsed cells were incubated with various heparin concentrations higher TFPI activities were recovered from cells that were grown in medium with high glucose concentration as compared to cells with low glucose culture conditions (Figure 7.4).

High glucose concentrations in the culture medium meant significantly higher postheparin TEPI activity on day 1 as well as on day 4 postconfluent $(n=12$; day $1: 99 \pm 14 \%$ vs $138 \pm 21 \%, \mathrm{p}<0.0001$; day $4: 172 \pm 30 \%$ vs $203 \pm 23 \%, \mathrm{p}<0.05$ ). A positive correlation between postheparin TFPI activity and glucose was found $(r=0.28, p<0.05)$.

Cell counts were performed on the first day of confluency. No difference in cell counts could be demonstrated between cell cultures with a low and high glucose medium $\left(n=24 ; 20.3 \pm 7.6 \times 10^{6}\right.$ cells $/ \mathrm{ml}$ versus $21.8 \pm 7.0 \times 10^{6}$ cells $\left./ \mathrm{ml}, \mathrm{NS}\right)$. An osmolarity study was performed using sorbitol; a culture without adding D-glucose 
or sorbitol served as a control. While cell cultures with $D$-glucose showed a significant increase of postheparin TFPI activity $(n=6 ;$ at $30 \mathrm{mmol} / \mathrm{l}: 91 \pm 6 \%$, at 60 mmol/l: $88 \pm 6 \%$ vs control $72 \pm 13 \%, \mathrm{p}<0.05$ ), no increase was seen with equal sorbitol concentrations in the culture medium.

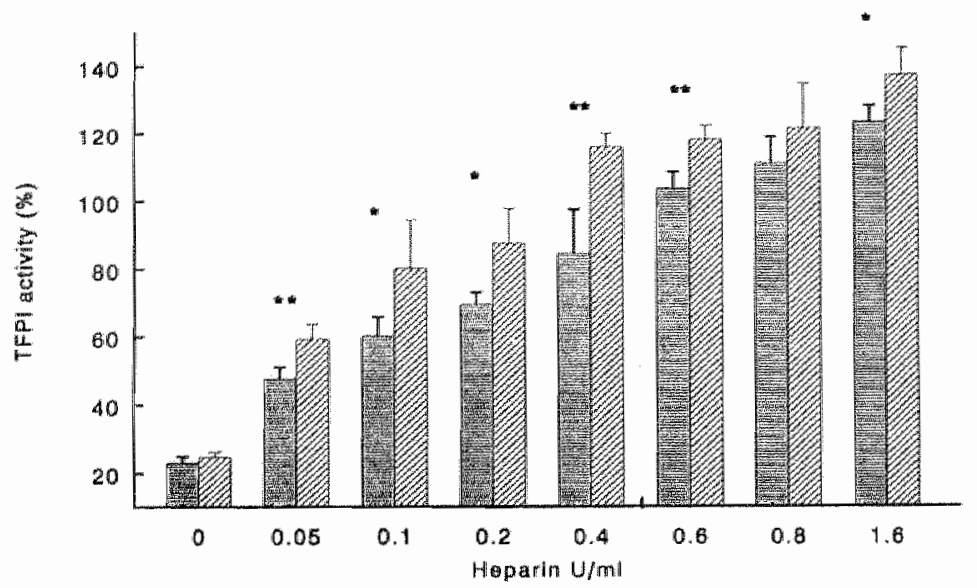

Figure 7.4 Effect of low and high glucose culture medium on TFPI activity. After incubation with various heparin concentrations TFPI release is measured in cultures of EC cultured in high glucose medium (35 mmol/l D-glucose; hatched bars) and in low glucose medium (7 mmol/1 D-glucose; black bars). " $p<0.01,{ }^{\text {"* }} p<0.001$.

When studying the effects of different insulin concentrations ( 0 to $65 \mathrm{mU} / \mathrm{l})$ in low and high glucose cell cultures, low insulin resulted in a higher postheparin TFPI activity in a high glucose culture (Figure $7.5, n=8 ; 121 \pm 3 \%$ vs $110 \pm 6 \%$, $p<0.05$ ). On the other hand, high insulin concentrations in high glucose cell cultures led to a decrease in postheparin TFPI activity, equal as could be found in the low glucose cell cultures. As a control experiment, insulin solvent (acetic acid) alone did not influence TFPI activity. In low glucose cell cultures, no evident effeci of insulin on postheparin TFPI activity was seen. Before heparin incubation, no differences in basal TFPI activity in the supernatants of the various cell cultures were observed. 


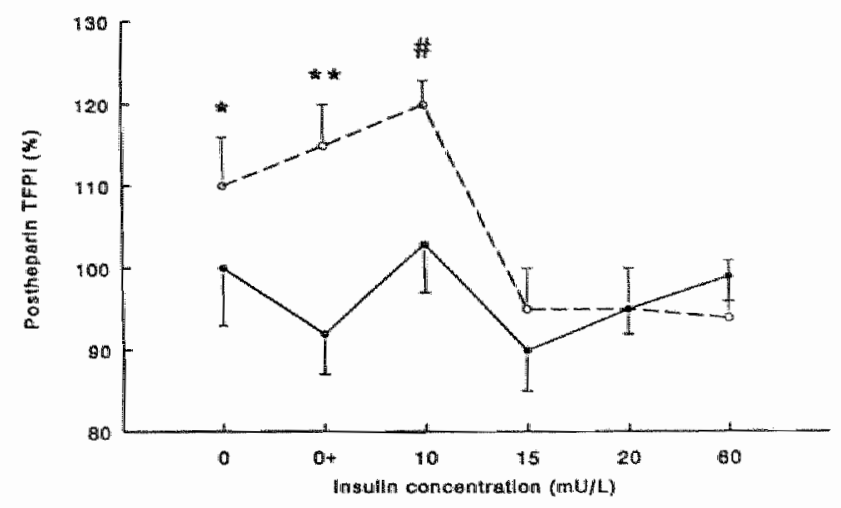

Figure 7.5 Influence of insulin on postheparin TFPJ release in relation to low and high glucose concentrations in culture medium. The effect of vatrous concentrations of insulin 0 to $60 \mathrm{mU} / \mathrm{l}$ ) in medium with low and high glucose on postheparin TFPI. - EC cultured in medium with 7 monol/l glucose, $O$ EC cultured in medium with 35 mmol/l gilucose, $0+$ insultin solvent (acetic acid); " $<0.05$, " $p<0.001$ vs insulin concentrations of 15,20 , and $60 \mathrm{mU} / \mathrm{l}$; " $p<0.05 \mathrm{vs}$ insulin concentration of 0 mU/, $p<0.00$ vs insulin concentrations of 15,20 , and $60 \mathrm{mU} / \mathrm{l}$.

\section{Discussion}

The present study demonstrates that heparin induces dosage and time dependently release of TFPI from cultured EC with a concomitantly decrease in EC-bound TFPI activity. D-glucose increases heparin-induced TFPI release from cultured EC, independently of the concentration of heparin, duration of confluence of the EC layers, and osmolarity. Insulin only affects postheparin TFPI release in high glucose EC cultures.

The release of TFPI from EC by heparin appeared to be dependent from the concentration of heparin, with a maximal TFPI release when the heparin concentration was between 0.4 and $0.6 \mathrm{U} / \mathrm{ml}$ during an incubation period of 10 minutes. This finding suggests a binding of TFPI to the cell surface in a saturable manner, which is supported by in vivo and in vitro studies ${ }^{18.14}$. In addition, a longer duration of incubation with heparin resulted in an increased TFPI release up till 30 minutes. However, a flattening of the TFPI release curve is observed after 10 minutes of incubation. Evidence has recently been provided for the existence of TFPl-specific glycosyl phosphatidylinositol (GPI)-anchored binding sites on external membranes ${ }^{20}$. There is support that this is also true for $\mathrm{EC}^{21}$. One could hypothesize that there exist heparin-unreleasable TFPI at GPI-anchored binding sites and heparin-releasable glycosaminoglycan-bound TFPI, both located at the 
endothelial cell surface. Our finding that cell-bound TFPI can only partially be released by heparin is compatible with this notion. Recently, an increased secretion and redistribution of cellular TFPI induced by heparin in EC cultures has been demonstrated ${ }^{22}$.

It appeared that TFPI release by heparin also depends upon TFPI activity in the culture medium during culturing. Lowering the TFPI activity in the culture medium by adding fresh medium during culturing resulted in a decreased TFPI release after heparin incubation. We were also able to show a significant positive correlation between pre- and postheparin TFPI activity. Apparently, there is an equilibrium between 'free' TFPI in the medium and endothelial cell-bound TFPI. In vivo, this is supported by the study of Kokawa et al., who found a positive correlation between free TFPI and endothelial cell-associated TFPI in hyperlipidemic patients $^{23}$.

Heparin released more TFPI from cells that were cultured in high glucose medium than from cells cultured in low glucose medium. This higher release was not caused by osmotic mechanisms or increased number of cells. This in vitro finding might provide a basis for our earlier observation of increased postheparin TFPI aclivity in type $\mathbb{1}$ diabetic patients ${ }^{2}$. A number of studies have demonstrated that high glucose in endothelial cell cultures results in increased levels of other endothelium-dependent hemostatic parameters like von Willebrand factor, t-PA and PAI-1 ${ }^{24.25}$. It is our notion that chronic high glucose levels affects the endothelial function in vitro as in vivo, resulting in increased TFPI release after heparin.

In diabetes, function and/or structure of endothelial glycosaminoglycans, could be altered. Animal studies suggest that in diabetes glycosaminoglycans are less negatively charged, due to the synthesis of low-sulfated heparan sulfate molecules ${ }^{26.27}$. TFPI is most likely bound to glycosaminoglycans with its highly positively charged COOH-terminus ${ }^{2 \alpha}$. We hypothesize that the increased TFPI release after heparin incubation of endothelial cell cultures with high glucose may therelore be explained by a weaker binding. This is supported by the fact that we were unable to find differences in basal (preheparin) TFPJ activity in the supernatants of EC cultured with low and high glucose medium. Alterations in function of glycosaminoglycans could be the result of nonenzymatic glycation, formation of advanced glycated endproducts and oxidative stress, as can be found in diabetic patients ${ }^{2 y-31}$. It has been shown that some effects of high glucose in endothelial cell cultures can be reversed by antioxidants ${ }^{32}$.

In the present study, low insulin levels resulted in higher TFPI release after heparin incubation only in the high glucose cultures, while high insulin levels in high glucose cultures led to decreased postheparin TFPI release. No effect of insulin was seen in the low glucose cell cultures. Abe et al. also found an effect of insulin only in endothelial cell cultures with high glucose ${ }^{33}$. In agreement with our results, 
an inverse correlation between heparin-stimulated TFPI antigen plasma levels and plasma insulin concentrations has recently been reported in $\operatorname{man}^{34}$.

In conclusion, heparin-stimulated release in EC cultures is parallelled by a decrease of TFPI activity at the EC surface. High D-glucose concentrations (in combination with low insulin concentrations) in EC cultures increases TFPI release by heparin. 


\section{References}

I. Jaffe EA. Endothelial cell structure and function, in Hoffiman R, Benj EJ Ir, Shatti SJ, Furie B, Cohen HJ (eds): Hematology: Basic Principles and Practice. New York, NY, Churchill Livingston 1991;1198-213.

2. Esmond CT, Owen WG. Identification of an endothellial cofactor for thrombincatalyzed activation of protein C. Proc Natl Acad Sci USA 1981;78:2249-52.

3. Bajaj MS, Kuppuswamy MN, Saito H, Spitzer SG, Bajaj SP. Cultured normal human hepatocytes do not synthesize lipoprotein-associated coagulation inhibitor: Evidence that endothelium is the principal site of its synthesis. Proc Natl Acad Sci USA 1990;87:8869-73.

4. Broze GI, Milletich JP. Characterization of the inhibition of tissue factor in serum. Blood 1987;69: 150-5.

5. Rao LVM, Rapaport SI. Studies of a mechanism inhibiting the initiation of the extrinsic pathway of coagulation. Blood 1987;69:645-51.

6. Girard TJ, Eddy $R$, Wesselschmidt RL, MacPhail LA, Likert KM, Byers MG, Shows TB, Broze GJ. Structure of the human lipoprotein-associated coagulation inhibitor gene. I Biol Chem 1991;266:5036-41.

7. Lindahl AK, Sandset PM, Abildgaard U. The present status of tissue factor pathway inhibitor. Blood Coagul Fibrinol 1992;3:439-49.

8. Novotny WF, Girard TJ, Miletich JP, Broze GJ. Purification and characterization of the lipoprotein-associated coagulation inhibitor from human plasma. I Biol Chem 1989;264:18832-7.

9. Sandset PM, Abildgaard U, Larsen ML. Heparin induces release of extrinsic pathway inhibitor (EPI). Thromb Res 1988;50:803-13.

10. Ross R, Glomset J, Harker L. Response to injury and atherogenesis. Am J Pathol 1977;86:675-84.

11. Fishman IA. Ryan GB, Karnowsky MJ. Endothelial regeneration in the rat carotid artery and the significance of endothelial denudation in the parthogenesis of myointimal thickening. Lab Invest 1975;32:339-51.

12. Leurs $P B$, van Oerle R, Hamulyák $K$. Wolftenbuttel BHR. Tissue factor pathway inhibitor in patients with IDDM. Diabetes 1995:44:80-4.

13. Leurs PB, van Oerle R. Wolffenbuttel BHR. Hamulyák K. Increased tissue factor pallway inhibitor (TFPl) and coagulation in patients with insulin-dependent diabetes mellitus. Thromb Haemostas 1997;77:472-6.

14. Edgell CS, McDonald CC, Graham JB. Permanent cell line expressing human factor VIII-related antigen established by hybridization. proc Natl Acad Sci USA 1983; 80:3734-7.

15. Emeis J, Edgell CS. Fibrinolytic properties of a human endothelial hybrid cell line (EA.hy 926). Blood 1988;71:1669-75. 
16. Lupu C, Lupu F, Dennehy U, Kakkar VV, Scully MF. Thrombin induces the redistribution and acute release of tissue factor pathway inhibitor from specific granules within human endothelial cells in culture. Arterioscler Thromb Vasc Biol $1995 ; 15: 2055-62$.

17. Sandset PM, Abildgaard U, Pettersen M. A sensitive assay of extrinsic coagulation pathway inhibitor (EPI) in plasma and plasma fractions. Thromb Res. $1987: 47: 389-400$.

18. Hansen JB, Sandset PM, Huseby KR. Huseby NE, Nordoy A. Depletion of intravascular pools of lissue factor pathway inhibitor (TFPl) during repeated or continuous intravenous infusion of heparin in man. Thromb Heamost 1996;76: $703-9$.

19. Hine $C$, Enjyoji $K$, Kamikubo $Y$, Kato $H$. Two distinct binding sites for tissue factor pathway inhibitor on endothelial cells. Thromb Haemost 1997; Abstraci PS1657:406.

20. Sevinsky JR, Rao LVM. Ruf W. Ligand-induced protease receptor translocation into caveolae: a mechanism for regulating cell surface proteolysis of the tissue tactor dependent coagulation pathway. I Cell Biol 1996;133:293-304.

21. Lupu C, Goodwin CA, Westmuckett AD, Emeis JI, Scully MF, Kakkar VV, Lupu F. Tissue factor pathway inhibitor in endothelial cells colocalizes with glycolipid microdomains/caveolae. Arterioscel Thromb Vasc Biol 1997:17:2964-74.

22. Lupu C, Poulson E, Roquefeuil S, Westmuckett AD, Kakkar VV. Lupu F. Cellular effects of heparin on the production and release of tissue factor pathway inhibitor in Inuman endothelial cells in culture. Arterioscler Thromb Vasc Biol 1999:19:2251-62.

23. Kokawa $T$, Enjyoji K, Kumeda K, Kamikubo $Y$, Harada-Shiba M, Kola $H$, Tsusihima M, Yamamota A, Kato H. Measurement of the free form of TFPI antigen in hyperlipidemia. Relationship between free and endothelial cell-associated forms of TFPI. Arterioscler Thromb Vasc Biol 1996; 16:802-8.

24. Porta M, la Selwa M, Molinatti P, Molinatti GM. In vivo studies of von Willebrand factor and other endothelial molecules in diabetic microangiopathy. In Endothellal Cell Function in Diaberic Microangiopathy: Problems in Methodology and Clinical Aspects. Vol, 9, Molinati GM, Bar RS, Belfiore IF. Porla M, Eds. Karger, Basel $1990 ; 156-63$.

25. Maiello M, Boeri D, Podesta F, Cagliero E, Vichi M, Odeti P. Adezati L, Lorenzi M. Increased expression of tissue plasminogen activator and its inhibitor and reduced fibrinolytic potential of human endothelial cells cultured in elevated glucose. Diabetes 1992;41:1009-15.

26. Kjellén $L$, Bielefeld $D$, Höök M. Reduced sulfation of liver heparan sullate in experimentally diabetic rats. Diabetes $1983 ; 32: 337-42$.

27. Raz I, Havivi $Y$, Yarom $R$. Reduced negative surface charge on arterial endothelium of diabetic rats. Diabetologia 1988;31:618-20. 
28. Valentin $S$, Larnkjoer $A$, Ostergaard $P$, flum Nielsen $J$, Nordfang $O$ Characterization of the binding between tissue factor pathway inhibitor and glycosaminoglycans. Thromb Res 1994;75:173-83.

29. Miyata T, Sugiyama S, Suzuki D, Inagi R, Kurokawa K. Increased carbonyl modification by lipids and carbohydrates in diabetic nephropathy. Kidney Int 1999; $71: \$ 54-6$.

30. Hammes HP, Alt A, Niwa T, Clausen JT, Bretzel RG, Brownlee MB, Schleicher ED. Differential accumulation of advanced glycation end products in the course of diabetic retinopathy. Diabetologia 1999;42:728-36.

31. Min C, Kang E, Yu SH, Shinn SH, Kim YS, Advanced glycation end products induce apoptosis and procoaculant activity in cultured human endothelial cells. Diabetes Res Clin Pract 1999;46:197-202.

32. Curcio F, Ceriello A. Decreased cultured endothelial cell proliferation in high glucose medium is reversed by antioxidants: new insights on the pathophysiological mechanisms of diabetic vascular complications. In Vitro Cell Dev Biol 1992; 28A:787-90.

33. Abe M, Ono J, Sato Y, Okeda T, Takaki R. Effects of glucose and insulin on cultured human microvascular endothelial cells. Diab Res Clin Pract 1990;9:287-95.

34. Cella G, Vettor R, Sbarai A, Rossi E, Rampin E, Macor C, Mussap M, Plebani M, Luzzatto G, Girolami A. Endothelial cell-associated tissue factor pathway inhibitor (TFPI) antigen in severe nondiabetic obese patients: effect of hyperinsulinemia. Semin Throm Hemost 1997;23:129-34. 


\section{Chapter 8}

General discussion and conclusions 


\section{General discussion and conclusions}

As long as there is no cure for diabetes mellitus, treatment is focused on attaining the best possible metabolic control to prevent the development of secondary complications on the short and long term. In 1993 the results of the Diabetes Control and Complication Trial indicated that a good metabolic control reduces the risk of developing microvascular complications in type 1 diabetic patients'. We therefore need markers which can identify those parients who are at risk for developing micro- and macrovascular complications in an early stage of their disease. Untill now, von Willebrand factor (VWF) appears to be such a marker. Because of its hemostatic endothelium-dependent characteristics we hypothesized that TFPI may also be a valuable marker of endothelial (dys)function in diabetic subjects. Not only did we find significantly higher pre- and postheparin TFPI activities in plasma of patients with type 1 diabetes mellitus without complications in comparison with healthy volunteers, but a strong positive correlation between TFPI activity and glycated hemoglobin as well (Chapter 3). This finding indicates that TFPI activity is affected by chronic hyperglycemia. Because of the fact that TFPI is mainly produced by and bound to the vascular endothelial cells, one may speculate that the increased TFPI activity in plasma of this group of type 1 diabetic subjects without clinically detectable (vascular) complications reflects early endothelial damage or dysfunction. If this is true, additional therapeutic interventions should be considered in these patients, especially with a poor metabolic control. Very recently it is demonstrated that optimisation of glycemic control in poorly controlled type 1 diabetic patients induces normalisation of TFPI activity ${ }^{3}$.

In the pathogenesis of atherosclerosis endothelial damage is an early feature. This is followed by a cascade of events (of which one important event is the activation of the tissue factor pathway), which eventually results in the development of the atherosclerotic plaque. Microvascular complications, especially microalbuminuria, are associated with an increased risk of developing cardiovascular diseases in diabetic and non-diabetic subjects ${ }^{45}$. It is thereby generally accepted that microalbuminuria reflects generalized angiopathy". Alterations in synthesis and/or function and/or structure of glycosaminoglycans in diabetes could form the pathophysiological basis of microalbuminuria?. In type 1 diabetic subjects with microalbuminuria we found significantly higher basal and postheparin TFPI activities as compared to diabetic subjects with no complications or with only retinopathy (Chapter 4), while the overall metabolic control in the three groups was equal. In addition, a strong correlation between basal TFPI activity and microalbuminuria could be demonstrated. While TFPI is most likely bound to the endothelial cell surface by glycosaminoglycans we hypothesize that the increased TFPI activity in type 1 diabetic subjects with microalbuminuria may be the result 
of altered endothelial glycosaminoglycan characteristics.

On the other hand, increased TFPl activity could also be triggered by a procoagulant state as can be found in diabetes mellitus. In patients with type 1 diabetes mellitus and microalbumimuria, increased TFPI activity and levels of prothrombin $\mathrm{F}_{1+2}$ fragments were seen (Chapter 5). However, we found no correlation between the two variables, suggesting that the increase in TFPI activity in plasma is more complex than just a reflection of a procoagulant state.

Recently, we learned from the results of the UK Prospective Diabetes Study that improved metabolic control also leads to a decrease in the risk of microangiopathy in patients with type 2 diabetes mellitus". In our population-based study, TFPI activity was increased in elderly subjects with a normal or impaired glucose tolerance (a state which precedes the development of type 2 diabetes mellitus) and type 2 diabetes mellitus (Chapter 6). However, there were no significant differences in activity seen between the three groups. One must take into account that TFPI activity was measured chromogenically and compared with a standard curve obtained from a pool of 45 healthy donors, with a mean age of $36 \pm 5$ years. It is known that TFPI activity is increasing with age. From these data, it may be concluded that TFPI probably can not be used as a marker of endothelial dysfunction to discriminate groups at risk in an elderly population.

In cultured endothelial cells, derived from an immortalized endothelial cell line (EA.hy 926), we were able to demonstrate that high glucose conditions, as in vivo, not only induce increased TFPI activity in the medium but also leads to an increased release of TFPI from the endothelial cell surface after heparin (Chapter 7). A positive correlation between postheparin TFPI activity and Dglucose concentration of the culture medium was found. Insulin only affected postheparin TFPI release in high glucose EC cultures. As mentioned earlier, diabetes is characterized by alterations in glycosaminoglycans. A possible explanation for these findings may therefore be glycation of glycosaminoglycans at the endothelial cell surface by high glucose levels, which in turn could result in an altered binding of TFPI to these glycosaminoglycans.

In conclusion, basal TFPI activity and TFPl release from endothelial cells after heparin is increased in vivo and in vitro by clronic hyperglycemic conditions. Although not specifically investigated, we hypothesize that chronic hyperglycemia may lead to alterations in metabolism and/or functional structure of glycosaminoglycans, resulting in altered binding characteristics between TFPI molecules and glycosaminoglycans at the endothelial cell surface. These changes may eventually play a rolle in the occurrence of cardiovascular events in patients with diabetes mellitus.

Could TFPI activity in plasma be the common denominator for some important factors (such as endothelial damage, resulting in a decreased anticoagulant potential 
at the surface of the endothelium, thus increasing the risk of thrombin formation on damaged endothelium) leading to the development of microvascular and cardiovascular complications in diabetes ? To answer this question, further (prospective) clinical trials and in vitro studies are needed. However, more reports of increased TFPI levels in patients with cardiovascular disease are emerging ${ }^{9.10}$. Crawley and others very recently demonstrated enhanced TFPI expression in the atherosclerotic vesse $1^{11,12}$. It was thereby colocalized with tissue factor suggesting a significant role of TFPI in the regulation of tissue factor activity. They also confirmed the localization of TFPI in macrophage-derived foam cells $s^{11}$. This may implicate an imporiant role of TFPI in counteracting the procoagulant state of these foam cells. However, an interesting finding has been reported whereby the procoagulant activity of tissue factor in foam cells, originating from monocytederived macrophages, appears not to be counterbalanced by an upregulation of TFPI activity ${ }^{13}$. This could result in a procoagulant environment at the site of the fatty streak and atherosclerotic plaque, eventually promoting cardiovascular events.

Several mechanisms play a role in the occurrence of diabetic complications such as increased oxidative stress, resulting in tissue damage ${ }^{14-16}$. Recently, it has been shown that oxidized LDL, as can be found in diabetic subjects, can upregulate adhesion molecules for monocytes ${ }^{17}$. In addition, activity of LDL-associated TFPI is impaired by lipoprotein oxidation ${ }^{18.19}$. This oxidative inactivation of LDLassociated TFPI may effectively neutralize its inhibitory action on tissue factor activity, compromising normal hemostasis.

Non-enzymatic glycation of proteins occurs at an accelerated rate in diabetes and can lead to the formation of advanced glycation end products (AGEs). An association of these AGEs with diabetic complications has been postulated ${ }^{20}$. Evidence for this association is mounting ever since ${ }^{2125}$. A specific integral membrane protein las been identified as a receptor for AGE (RAGE) in endothelium, vascular smooth muscle cells and monocyte-derived macrophages ${ }^{26}$. This finding suggests a potential relevance of AGE-RAGE interactions for modulating properties of these tissues ${ }^{2729}$. One may therefore speculate that an allered TFPI activity in diabetes could be the result of functional alterations in the endothelial cells caused by AGEs.

Is there at the moment a place in the daily clinical practice for the measurement of one or more endothelium-dependent factors? Unfortunately, as mentioned before, up to the present only $\checkmark W F$ appears to be of predictive value when it concerns the development of micro- and macroangiopathic complications in specific groups of diabetic subjects ${ }^{2}$. However, there is still a lack where it concerns the potential of an endothelium-dependent factor to predict the development of complications in the individual diabetic patient. Besides, there is also the problem of differences between specific methods for measuring an endothelium-dependent factor. TFPI can be measured with a chromogenic assay (which is expressed in $\%$ with regard to 
standardized TFPI activity, measured in a plasma pool obtained from healthy donors), a clotting assay or as total TFPI antigen or free TFPI antigen with an ELISA. At this moment, there is no answer to the question which of these assays would be best to use.

One possible solution for the practical use of endothelium-dependent factors to predict complications may be the determination of cut-off points and the assessment of sensitivity, specificity, and the positive and negative predictive values of the different factors. One may even combine two or more factors in the framework of 'risk stratification' to enhance the potential of prediction. Uniformity in the determination of the levels of cut off for the different factors is thereby of utmost importance.

In conclusion, TFPI activity is increased in diabetes mellitus, especially in subjects with type 1 diabetes and microalbuminuria. Poor metabolic control appears to increase TFPI activity. Although the results in this thesis indicate that TFPI may be a marker of endothelial dysfunction, especially in type 1 diabetes, more (prospective) studies are needed to confirm this postulation and to further elucidate its power to predict cardiovascular events. Also the exact role of TFPI in the pathogenesis of cardiovascular events warrants further investigation. 


\section{References}

1. Diabetes Control and Complications Trial Research Group. The effect of intensive treatment of diabetes on the development and progression of long-term complications in insulin-dependent diabetes mellitus. $\mathrm{N}$ Engl J Med 1993;329: $977-86$.

2. Stehouwer CDA, Stroes ESG, Hackeng WHL, Mulder PGH, den Otterlander GJH. Von Willebrand factor and development of diabetic nephropathy in insulin-dependent diabetes mellitus. Diabetes 1991:40:971-6.

3. Rigla M. Mateo J, Fontcuberta I, Souto ${ }_{C}$, de Leiva A, Pérez A. Normalisation of tissue factor pathway inhibitor activity after glycaemic control optimisation in type 1 diabetic patients. Thromb Haemost 2000;84:223-7.

4. Mogensen CE. Microabuminuria predicts clinical proteinuria and early mortality in maturity onset diabetes. N Engl J Med 1984;310:356 63.

5. Yudkin JS, Forrest RD, Jackson CA. Microalbuminuria as predictor of vascular disease in non-diabetic subjects. Lancet 1988;ii:530-3.

6. Deckert $T$, Feldt-Rasmussen B, Borch-Johnsen $K$, Jensen $T$, Koloed-Enevoldsen $A$. Albuminuria reflects widespread vascular damage. The Steno hypothesis. Diabetologia $1989 ; 32: 216$-26.

7. Jensen T. Pathogenesis of diabetic vascular disease: evidence for the role of reduced heparan sulfate proteoglycan. Diabetes 1997;46(S2):S98-100.

8. UK Prospective Diabetes Study (UKPDS) Group. Intensive blood-glucose control with sulphonylureas or insulin compared with conventional treatment and risk of complications in patients with type 2 diabetes (UKPDS 33). Lancet 1998;352; 837-53.

9. Falciani M, Gori AM, Fedi S, Chiarugi L, Simonetti 1 , Dabizzi RP, prisco D, Pepe G, Abbate R, Gensini GF, Neri Serneri GG. Elevated tissue factor and tissue factor pathway inhibitor circulating levels in ischaemic heart disease patients. Thromb Haemost 1998;79:495-9.

10. Soejima H, Ogawa H, Yasue H, Kaikita K. Nishiyama $K$, Misumi K, Takazoe K. Miyao $Y$, Yoshimura M, Kugiyama $K$, Nakamura $S$, Tsuji 1 , Kumeda $K$. Heightened tissue factor associated with tissue factor pathway inhibitor and prognosis in patients with unstable angina. Circulation 1999;8:2908-13.

11. Crawley I, Lupu F, Westmuckett AD, Severs NJ Kakkar VV, Lupu C. Expression, localization, and activity of tissue factor pathway inhibitor in normal and atherosclerotic human wessels. Artertoscler Thromb Vasc Biol 2000;20: 1362-73.

12. Kaikita K, Takeya M, Ogawa H, Suefuji $H$, Yasue H, Takahashi K. Co-localization of tissue factor and tissue factor pathway inhibitor in coronary atherosclerosis. I Pathol 1999; 188:180-8. 
13. Petit L, Lesnik P, Dachet C, Moreau M, Chapman MJ. Tissue Factor padhway inhibitor is expressed by human monocyte-derived macrophages: relationship to tissue factor induction by cholesterol and oxidized LDL. Arterioscler Thromb Vasc Biol 1999; 19:309-15.

14. Baynes JW. Role of oxidative stress in development of complcations in diabetes. Diabetes $1991 ; 40: 405-12$.

15. Giugliano D, Ceriello A. Paolisso G. Oxidative stress and dabetic vascular complications. Diabetes Care 1996:19:257-67.

16. Watts GF, Playford DA. Dyslipoproteinaemia and hyperoxidative stress in the pathogenesis of endothelial dysfunction in non-insulin dependent diabetes mellitus: a hypothesis. Atherosclerosis 1998;141:17-30.

17. Kita T, Kume N, Ishii K, Horiuchi H, Arai H, Yokode M. Oxidized LDL and expression of monocyte adhesion molecules. Diabetes Res Clim Pract 1999:45:123-6.

18. Lesnik $\mathbb{P}$, Dentan $C$, Vonica A, Moreau M, Chapman MJ. Tissue factor patlway inhibitor activity associated with $L D L$ is inactivated by cell- and coppermediated oxidation. Arterioscler Thromb Vasc Biol 1995; 15:1121-30.

19. Ettelaie C, Wilbourn BR, Adam JM, James NJ, Bruckdorter KR. Comparison of the inhibitory effects of apo $B_{1 \Leftrightarrow}$ and tissue factor pathway inhbitor on tissue factor and the influence of lipoprotein oxidation. Arterioscler "Thromb Vasc Biol 1999;19: $1784-90$.

20. Brownlee MB, Cerami A, Vlassara H. Advanced glycosylation end-products in tissue and the biochemical basis of diabetic complications. $N$ Engl J Med 1988;318: $1315-21$.

21. Berg TJ, Snorgaard O, Faber J, Torjesen PA, Hildebrandt P, Mehlsen J, Hanssen KF. Serum levels of advanced glycation end products are associated with left ventricular diastolic function in patients with type 1 diabetes. Diabetes Care 1999; 22: 1186-90.

22. Killnoyd BK, Berg TJ, Birkeland KI. Thorsby P. Hanssen KF. Serum levels of advanced glycation end products are increased in patients with type 2 diabetes and coronary heart disease. Diabetes Care 1999;22:1543-8.

23. Miyata $T$, Sugiyama $S$, Suzuki $D$, Inagi $R$, Kurokawa $K$. Increased carbonyl modification by lipids and carbohydrates in diabetic nephropathy. Kidney Int 1999; $71(\$): \$ 54-6$.

24. Hammes HP: Alt A, Niwa T, Clausen JT, Bretzel RG. Brownlee MB, Schleicher ED. Differential accumulation of advanced glycation end products in the course of diabetic retinopathy. Diabetologia 1999:42:728-36.

25. Min C, Kang E, Yu SH, Shinn SH, Kim YS. Advanced glycation end products induce apoptosis and procoaculant activity in cultured human endothelial cells. Diabetes Res Clin Pract 1999:46:197-202. 
26. Brett I, Schmidt AM, Yan SD, Zou YS, Weidman E, Pinksy D, Nowygrod R, Neeper M, Przysiecki C, Shaw A. Survey of the distribution of a newly characterized receptor for advanced glycation end products in tissues. Am J Pathol $1993 ; 1.43: 1699-712$.

27. Kirstein M, Aston $C$, Hintz R, Vlassara H. Receptor-specific induction of insulinw like growth factor 1 in human monocytes by advanced glycosylated end productmodified proteins. I Clin Invest 1992;90:439-46.

28. Yamagislii $S$, Fujimori $H$, Yonekura $H$, Yamamoto $Y$, Yamamoto $H$. Advanced glycation end products inhibit prostacyclin production and induce plasminogen activator inhibitor-1 in human microvascular endothelial cells. Diabetologia 1998;41: $1435-41$.

29. Sobal G, Sinzinger H, Menzel EI. Binding of long-term glycated low density lipoprotein and AGE-albumin by peripheral monocytes and endothelial cells. J Recept Signal Transduct Res 1999:19:267-81. 


\section{Chapter 9}

\section{Samenvatting}




\section{Samenvatting}

Tissue factor pathway inhibitor (weefselfactor stolweg remmer) in patiënten met diabetes mellitus.

Diabetes mellitus ofwel suikerziekte wordt gekenmerkt door het optreden van vroegtijdige atherosclerose, zich uitend in hart- en vaatziekten. Uit recente internationale studies zoals de DCCT (Diabetes Control and Complication Trial) en UKPDS (United Kingdom Prospective Diabetes Study) blijkt dat hoe slechter de diabetesregulatie, des te groter de kans is op de ontwikkeling van complicaties. Daarbij spelen processen als endotheelbeschadiging van de vaatwand, stoomissen in de vetstofwisseling en stollingsproblemen een belangrijke rol. Daar diabetes mellitus tot op heden niet te genezen is, is de huidige behandeling van patiënten gericht op een zo optimaal mogelijke regulatie van de bloedglucosespiegels ter voorkoming van complicaties op korte en lange termijn zoals hart- en vaatziekten (macroangiopathie), nierfunctieverlies (nefropathie), aantasting van de netvliesvadijes van de ogen (retinopathie) en zenuwbeschadiging (neuropathie). Tot nu toe zijn er een aantal zogenaamde endotheelafhankelijke factoren (eiwitten zoals von Willebrand factor ( $V W F$ ), tissue plasminogen antigen ( $t-P A)$, plasminogen activator inhibitor- 1 (PAI- 1 ) en thrombomoduline) bekend, die bij diabetespatiënten met hart- en vaatziekten verhoogd in het bloed aanwezig zijn. De gedachte is dat deze verhoogde spiegels de ontwikkeling en aanwezigheid van complicaties zoals vaatwandschade weerspiegelen. De genoemde factoren spelen alle een rol in het stollingsmechanisme (hemostase) van lhet bloed.

Halverwege de jaren tachtig werd een nieuw eiwit met een antistollende werking geïdentificeerd, dat essentieel bleek te zijn voor de remming van de zogenaamde extrinsieke stolweg ofwel de door weefselfactor geünitieerde stolweg (= tissue factor pathway). Het eiwit werd derhalve aanvankelijk EPI (extrinsic pathway inhibitor), later TFPI (tissue factor pathway inhibitor) genoemd. TFPI wordt door de bekledende endotheelcellen van de vaatwand geproduceerd. Na productie wordt het eiwit grotendeels, warschijnlijk via glycosaminoglycanen, aan de endotheelcellen gebonden, terwijl een kleiner gedeelte gebonden aan lipoproteinen en bloedplaatjes in het bloed wordt teruggevonden. Slechts een zeer kleine fractie is ongebonden in het bloed aanwezig. TFPI kan van het vaatendotheel 'losgemaakt' worden door middel van heparine en kan als TFPI activiteit met behulp van een zogenaande chromogene meetmethode in het bloedplasma gemeten worden. TFPI oefent zijn antistollende werking zowel in het bloedplasma als aan het oppervlak van de endotheelcellaag van de vaatwand uit.

Een van de eerste fases in het ontstaan van atherosclerose is (functionele) schade aan het endotheel van de vaatwand. Men zou daarom kunnen veronderstellen dat 
TFPI een merker zou kunnen zijn voor de aanwezigheid van vaatschade. In een eerste studie met patiënten met diabetes mellitus type 1 zonder complicaties hebben wij het mogelijk effect van diabetes op TFPI onderzocht (Hoofdshuk 3). Allereerst bleek dat patiënten met diabetes mellitus type 1 hogere TFPI activiteit in hun plasma verbonden dan gezonde proefpersonen. Dit was zowel voor als na toediening van heparine. Bovendien werden bij patiënten, die slecht waren gereguleerd wat betreft de diabetes, een beduidend hogere TFPl activiteit in het plasma gemeten dan in patiënten met een goede metabole controle. Er bestond een duidelijk verband tussen de mate van bloedglucoseregulatie en de hoogte van TFPI activiteit, d.w.z. hoe slechter de bloedglucoseregulatie (gemeten aan de hand van het geglyceerd hemoglobine ofwel $\mathrm{HbA}_{\mathrm{lc}}$ ), des te hoger de TFPl activiteit in het plasma van het bloed. Uit deze gegevens lijkt TFPI activiteit een mogelijke merker van (vroege) endotheelschade te zijn.

Om dit nader te onderzoeken werd TFPI activiteit voor en na heparinetoediening gemeten in diabetespatiënten type 1 met en zonder complicaties (Hoofdstuk 4). Patiënten met microalbuminurie (als uiting van dreigende nefropathie) bleken zowel voor als na toediening van heparine een significant hogere TFPI activiteit te hebben in vergelijking tot patiënten zonder complicaties of met alleen retinopathie. Daar microalbuminurie algemeen beschouwd wordt als een uiting van gegeneraliseerd vaatlijden lijken de resultaten van dit onderzoek de hypothese van TFPI als merker voor vaatschade te ondersteunen.

Echter, diabetes wordt onder meer gekenmerkt door een verhoogde stollingsneiging (procoagulante status). Men zou daarom ook kunnen veronderstellen dat een verhoogde TFPI activiteit in diabetespatiënten een reactie zou kunnen zijn op deze procoagulantie. Dit werd nader bestudeerd in gezonde proefpersonen en patiënten met type 1 diabetes (Hoofdstuk 5). Ondanks het feit dat een verhoogde stollingsneiging in diabetespatiënten ten opzichte van gezonde vrijwilligers kunnen worden aangetoond, kon geen verband tussen deze procoagulante toestand en TFPI activiteit worden gevonden.

De toestand van een zogenaande gestoorde glucose tolerantie (IGT) wordt beschouwd als overgangsfase in de ontwikkeling van diabetes mellitus type 2 (vroeger ook wel ouderdomsdiabetes genoemd). Het optreden van zowel IGT als diabetes mellitus neemt toe met de leeftijd. Niet alleen de leeftijd, maar ook IGT en diabetes geven aanleiding tot een verhoogde kans op het optreden van hart-en vaatziekten. In Hoofdstuk 6 werd de TFPI activiteit in gezonde oudere personen en oudere personen met een gestoorde glucose tolerantie dan wel oudere patiënten met. diabetes mellitus type 2 bestudeerd. In dezelfde populatie werd tevens VWF, I-PA, PAl-1 en thrombomoduline nader onderzocht. In de verschillende groepen konden geen verschillen in TFPI activiteit of thrombomoduline spiegels worden vastgesteld. Anderzijds werden ten opzichte van de gezonde ouderen verhoogde warden van vWF antigeen, $\mathrm{t}$-PA antigeen en PAI-1 activiteil in oudere personen met IGT en 
diabetes gevonden. Wel was er een positieve relatie tussen de mate van metabole regulatie enerzijds en TFPI activiteit en vWF anderzijds. Ook de mate van eiwituitscheiding in de urine was gecorreleerd met TFPI activiteit, WWF en PAI-1 activiteit. Geconcludeerd kan worden dat niet alleen in oudere patiënten met diabetes type 2, maar ook in oudere personen met IGT reeds verschillende endotheelatharkelijke factoren zijn verhoogd, hetgeen zou kunnen wijzen op endotheelschade. Daarentegen lijkt TFPI activiteit bij ouderen minder goed bruikbaar als merker voor vaatwandschade.

Om de effecten van diabetes op TFPI activiteit nader te kunnen bestuderen werden experimenten uitgevoerd met gekweekte humane endotheelcellen, die 'onsterfelijk' waren gemaakt (Hoofdstuk 7). Nadat endotheelcellen in kweekmedia met verschillende concentraties glucose waren gekweekt, werden deze cellen vervolgens gedurende 10 minuten geïncubeerd met heparine. Hierna werd TFPI activiteit in het supernatant en aan het celoppervlak gemeten. Allereerst bleek hogere heparineconcentraties tot $0.6 \mathrm{U} / \mathrm{ml}$ te leiden tot toename in TFPI activiteit. Daarnaast kon worden aangetoond dat met name gedurende de eerste 10 minuten heparine het TFPI van het oppervlak van de endotheelcellaag vrijmaakte. Heparine leidde tot hogere TFPl activiteit in celkweken met hoge glucoseconcentraties, onafhankelijk van het aantal endotheelcellen en osmolariteit. Insuline toegevoegd aan de kweekmedia bleek alleen invloed te hebben op de TFPI activiteit na heparine in geval van kweekmedia met hoge glucoseconcentraties. Een lage insulineconcentratie in combinatie met een hoge glucoseconcentratie resulteerde in verhoogde TFPI activiteit, terwijl een hoge insulineconcentratie leidde tot tegengestelde effecten. Uit deze experimenten blijkt in ieder geval dat hoge glucosespiegels tot veranderde TFPI activiteit leiden.

Geconcludeerd kan worden dat zowel basale TFPI activiteit als ook na toediening van heparine is verhoogd in vivo en in vitro door chronische hyperglycemische condities. Hoewel dit niet specifiek door ons is bestudeerd, hebben wij de hypothese dat deze chronische hyperglycemie zou kunnen leiden tot veranderingen in metabolisme en/of structuur van glycosaminoglycanen, hetgeen zou kunnen resulteren in veranderde bindingskarakteristieken tussen TFPI moleculen en glycosaminoglycanen aan het celoppervlak van het vaatendotheel. Deze veranderingen zouden uiteindelijk een rol kunnen spelen bij het optreden van harten vaataandoeningen in diabetespatiënten.

De laatste jaren verschijnen steeds meer publicaties over verhoogde TFPI spiegels in patiënten met cardiovasculaire aandoeningen. Verschillende mechanismen zijn belangrijk woor het optreden van complicaties bij diabetes, zoals verhoogde oxidatieve stress, leidend tot weefselschade. Men heeft aangetoond dat door oxidatie TFPI, gebonden aan LDL-cholesterol, in activiteit inboet, waardoor het evenwicht in hemostase in gevaar komt, hetgeen kan resulteren in een verhoogde 
stollingsneiging. Ook de vorming van zogenaamde advanced glycation end products (AGEs) wordt geassocieerd met complicaties in diabetespatienten. Verschillende studies suggereren dat AGEs via specifieke receptoren de functies van cellen, inclusief de endotheelcellen van de vaatwand, kunnen beinvoeden.

Is er in de dagelijkse praktijk (reeds) een plaats voor de bepaling van een of meer van de endotheelafhankelijke factoren zoals TFPI, VWF, t-PA, PAI-1 en thrombomoduline? Tot op heden lijkt alleen vWF van voorspellende waarde te zijn waar het de ontwikkeling betreft van micro- en macrovasculaire complicaties in specifieke groepen van diabetespatiënten. Echter, ten aanzien van het vermogen van een factor om in een individuele patiënt de ontwikkeling van complicaties te voorspellen bestaat vooralsnog geen potentiële kandidaat. Eén van de problemen waartegen men aanloopt is dat er verschillende meettechnieken kunnen bestaan voor het meten wan een factor. Zo kan TFPI met behulp van een chromogene methode, een stolmethode, en een ELISA gemeten worden. Vooralsnog is het niet duidelijk welke methode het beste is om te gebruiken.

Een mogelijke oplossing ten behoeve van praktische bruikbaarheid van endotheelafhankelijke factoren om complicaties te voorspellen zou de uniforme bepaling van zogenaamde cut-off points zijn, waarmee sensitiviteit, specificiteit, en positieve en negatieve predictieve waarden van de verschillende factoren vastgesteld kunnen worden. Men zou twee of meer factoren kunnen combineren in het kader van risico stratificatie om het vermogen van voorspellen te verhogen. Het vermogen de ontwikkeling van complicaties in een individu met diabetes te voorspellen kan leiden tot optimale preventieve maatregelen.

Resumerend kan gesteld worden dat TFPI activiteit is verhoogd in diabetes mellitus, met name in patiënten met diabetes mellitus type 1 en microalbuminurie. Slechte metabole controle van de diabetes blijkt TFPI activiteit te verhogen. Hoewel de resultaten beschreven in deze thesis suggereren dat TFPI een mogelijke merker van endotheelfunctie, zijn meer (prospectieve) studies nodig on dit te bevestigen. Ook de rol van TFPI bij de ontwikkeling van cardiovasculaire aandoeningen verdient verder onderzoek. 


\section{Dankwoord}




\section{Dankwoord}

'Als je eenmad specialist in een perifeer ziekenhus wordt. kun je je promotieonderzoek verder wel vergetten' is een vaak geuite opmerking wanneer een specialist het universitaire centrum voor een perifeer centrum verruilt. Sinds ik in juli 1996 Maastricht verrullde voor Goes leek dit ook voor mij op te gaan. Al gaw merkte ik dat met de drukke werkzaamheden de grip op de tjd om het proefschrift af te schrjven steeds zwakker werd. Naarmate dit besef meer tot mij doordnong, werd besloten de zomervakanties door te brengen in wakantichuisjes in inspirerende oorden, om alsnog het proefschrift af te ronden. Aldus werd het nuttige met het aangename met succes verenigd. Uiteraard heb ik daarbij de nodige steun onderwonden wan vele personen. Zonder iemand te kort te willen doen, zou ik wan de gelegenheid gebruik willen maken om aan een aantal van hen mijn dankwoord te richten.

Allereerst denk ik hierbij aan Dr BHR Wolfenbuttel. Beste Bruce, de basis van dit proefschrift lag in New Orleans, alwaar wij een congres over $L p(a)$ bezochten. Door de vele controverses omtrent Lp(a) was ons duidelijk geworden dat hiermee geen eer te behalen viel. Het was tijdens een etentje dat jij voor het eerst het woord TFPI liet vallen. Vanaf die tijd was het onderwerp voor toekomstig onderzoek duidelijk geworden. Voor mij ligt jouw kracht vooral in het optimal beschikbaar maken van de randwoorwaarden, warmee wetenschappelijk onderzoek maximaal verricht kan worden. Door altijd weer de nodige obstakels te beslechten makkte jij het voor mij mogelijk om in alle vrijheid aan het onderzoek te werken. De ongedwongenheid en het (schijnbaar) afwezig zijn van beperkingen makkten wetenschappelijke inspanningen voor mij een feest. Met plezier kijk ik echter niet alleen terug naar deze periode in Maastricht, maar ook naar onze gezamenlijke buitenlandse studiereizen. Die keer dat wij gierend van het lachen, maar badend in het angstzweet, met een kleine ATR-42 van Air Exel vanaf Beek naar Schiphol stoer windkracht 9 trotseerden zal ik nooit vergeten.

Dr K Hamulyák, beste Karly, jouw kritisch commentaar op alles wat met hemostase te maken heeft heb ik me altijd zeer aangetrokken en daarom ook enorm gewaardeerd. Daarnaast mocht ik zonder enig probleem van al jouw laboratoriumfaciliteiten gebruik maken, wat voor mij als onderzoeker een ongekende luxe betekende. Hierdoor kon met name mijn in vitro studie verder gestalte krijgen. Voor dit alles ben ith je dan ook buitengewoon orkentelijk.

Prof dr AC Nieuwenhuijzen Kruseman, beste Arie, jou ben ik zeer dankbaar voor het feit dat jij mij, bij mijn aankomst in Maastricht in 1989, het bijzondere van de Endocrinologie weer liet zien. Door mijn ervaringen als arts-assistent in opleiding op jouw afdeling heb ik met de endocrinopathologie in de wolle breedte kunnen kennismaken in een steer die vrij uniek genoemd kan worden binnen een academische setting. Jouw stimulerende leiding in wetenschappelijk onderzoek heeft ertoe bijgedragen dat de afdeling foreerde en in thorte tijd nationale en internationale bekendheid genoot op het gebied van diabetesonderzoek. Het was voor mij een genot dat ik hiervan deel mocht uitmaken. De goede relaties met Nicolaas Schaper en Jean-Pierre Sels hebben mij eveneens in positieve zin beinvloed. 
Prof John S Yudkin, I'm very grateful that you were willing to review this thesis as a nember of the external rewiew commitee. Your critical remarks and considerations were well taken.

Met name wil ik René van Oere noemen, hoofdanalist van het Laboratorium Hematologie, zonder wiens inbreng de uitwerking wan dit TFPl-onderzoek nooit tot de huidige vorm zou zün gekomen. Beste René, woorden schieten mü te kort on mijn dankbaarheid te uiten voor alles wat je met de nodige overtuging en enthousiasme voor mij hebl gedaan. De betekenis wan jouw inzet, zowel praktisch als inhoudelijk, voor dit onderzoek is voor een ieder welbekend, en kan niet vaak genoeg onderstreept worden. Mijn eerste schreden in het laboratorium geschiedde onder jouw hoede, uireindelijk resulterend in een niet aflatende groei van onze "turbocellen". Al vanaf de eerste dag dat ik Maastricht had verlaten, miste ik onze levendige en soms langdurige discussies; weel plezier heb ik ook beleetd aan onze soms eindeloos lijkende famasieèn, die wij de vrije loop lieten on probleemstellingen te attaqueren. Je schuwde ook geen moment van educatie: lijdens ons hemostasecongres in Jeruzalem ervoer je aan den lije wat de sabbat voor gelovigen in de praktijk betekende. De betekenis van een autoloze zondag was voor jou blijkbaar meer dan het gevolg van een oliecrisis. René, ik hoop dat je alls paramimf deze promotie ook een beetje als jouw promotie zult beschouwen.

Dr MJ Lindhout, beste Theo, jouw kritische commentaren als biochemicus gedurende de ontwikkeling en uitwoering van met name de in vitro experimenten heb ik zeer op prijs gesteld.

Alain Schauwaert wil ik dankzeggen, niet alleen voor de verleende diensten op het laboratorium, maar vooral als vriend voor het realiseren van het woor mij essentiêle adagium 'mens sana in corpore sano' middels onze frequente wedstrijden op de tennisbaan vanaf de periode die wij in de zusterflat hebben doorgebrach in hel begin van onze Maastrichtse tijd. Alain, met veel genoegen denk ik ook terug aan andere geestesverrumende activiteiten als onze Spanse lessen, die als rustpunten in hei. wetenschappelijk geweld werden ervaren. Zuid-Amerika zal toch nog eens ook doon mij worden ontdekt!

Een proefschrift kan heden ten dage slechts na cen perfect redigeren nak de drukker: alleen Tiny Wouters lijkt daartoe in staat te zijn. Beste Tiny, je hebt jouw onschabare waarde voor een promovendus wederom weten te bewijzen. Ook jouw vertrouwen in een goede afloop van dit boekje heet mij in de loop der jaren gestimuleerd, waarvoor mijn dank.

Mam, het is duidelijk dat zonder jou dit boekje er niel zou zijn geweest. Jouw niet afatend vertrouwen in mij is heel mijn leven tot steun geweest. Lieve Ries, in woor en tegenspoed, ik zou niet weten welke manier van bedanken het geduld wall je de afgelopen jaren hebt moeten opbrengen recht zou doen, maar nu er weer meer hijd beschikbaar lijkt te komen kunnen we tesamen in ieder geval intenser van het leven genieten. Ons nieuw onderkomen is daartoe een goede eerste aanzet. 


\section{Curriculum Vitae}




\section{Curriculum Vitae}

De auteur van dit proefschrift werd op 21 januari 1958 te "s-Hertogenbosch geboren. Op het Sint Janslyceum werd het Gymnasium B doorlopen, waarna in 1976 aan de Rijksuniversiteit Utrecht de studie Geneeskunde werd gestart. In 1984 werd het artsexamen afgelegd. In datzelfde jaar werd tevens deskundigheid Stralenbescherming nivo 3 behaald aan het JA Cohen Instituut, Interuniversitair Instituut voor Radiopathologie en Stralenbescherming te Leiden. Vanaf 1984 volgde thij de opleiding tot internist, aanvankelijk in Catharina Ziekenhuis Eindhoven (opleider Dr HFP Hillen), later in het Academisch Ziekenhuis Maastricht (opleider Prof Dr JA Flendrig). In de laatste periode van de opleiding werd tevens de opleiding in het aandachtsgebied Nefrologie (opleider Prof Dr JP van Hooff) afgerond. In 1991 vond registratie als internist-nefroloog plaats. In aansluiting hierop volgde hij de opleiding in het aandachtsgebied Endocrinologie (opleider Prof $\operatorname{Dr} A C$ Nieuwenhuijzen Kruseman); het was in deze periode dat een begin werd gemaakt met het huidig beschreven promotieonderzoek. Vanaf 1 juli 1996 is hij als internist-nefroloog werkzaam in hel Oosterscheldeziekenhuis te Goes. 